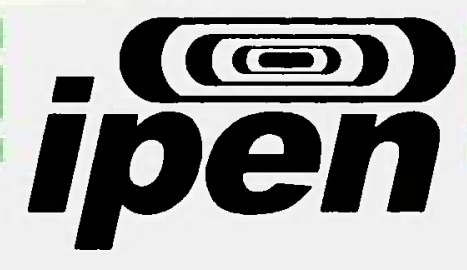

AUTARQUIA ASSOCIADA À UNIVERSIDADE DE SÃO PAULO

\title{
O CONSUMISMO COMO UM FATOR DE RELEVÂNCIA NA DEGRADAÇÃO AMBIENTAL GLOBAL - SITUAÇÃO ATUAL E ANÁLISE DAS POSSÍVEIS AÇÕES DE MITIGAÇÃO
}

\author{
WAGNER LUÍS ANDREASSA
}

Dissertação apresentada como parte dos requisitos para obtenção do Grau de Mestre em Ciências na Área de Tecnologia Nuclear - Reatores.

Orientadora:

Dra. Gaianê Sabundjan 
INSTITUTO DE PESQUISAS ENERGÉTICAS E NUCLEARES

Autarquia associada à Universidade de São Paulo

O CONSUMISMO COMO UM FATOR DE RELEVÂNCIA NA DEGRADAÇÃO AMBIENTAL GLOBAL - SITUAÇÃO ATUAL E ANÁLISE DAS POSSÍVEIS AÇÕES DE MITIGAÇÃO

WAGNER LUÍS ANDREASSA

24.074

Dissertação apresentada como parte dos requisitos para a obtenção do Grau de Mestre em Ciências na Área de Tecnologia Nuclear - Reatores

Orientadora:

Dra. Gaianê Sabundjan 


\section{DEDICATÓRIA}

Ao senhor meu Deus, por me guiar em todas as horas, e por me carregar quando necessário.

A Márcia minha esposa e aos meus filhos Renata e Fernando, por darem sentido à minha vida.

A minha mãe e meu pai (in memorium) por toda a sua força e exemplo de vida que me proporcionaram, que sem isso não chegaria a lugar algum. 
Ao professor Dr. Luiz Antonio Mai, por toda a sua e ajuda e incentivo para o sucesso deste trabalho.

A professora Dra. Gaianê Sabundjan, por toda a sua boa vontade e paciência.

A minha esposa Márcia pela paciência e amor, sem isso não teria conseguido finalizar o trabalho.

Aos pais de minha esposa Sr. Affonso e Sra. Deolinda por todo o apoio a mim dispensado nas minhas estadias em São Paulo.

A sempre atenciosa equipe da secretaria do ensino.

As atenciosas secretarias do CEN, Cida e Elsa, sempre com a resposta as nossas indagações.

Aos amigos que da hora do café pelo tempo que passamos juntos.

Aos companheiros da sala dos bolsistas, pelo companheirismo que se formou nesse período.

A todos aqueles que contribuíram para este trabalho, direta e indiretamente, muitas vezes despercebidos. 
Não há pecado maior do que o excesso da ganância.

Não há mal maior do que querer sempre mais.

Não há maior calamidade do que a mania do sucesso.

Quem se contenta com o necessário vive numa paz imperturbável. 


\title{
O CONSUMISMO COMO UM FATOR DE RELEVÂNCIA NA DEGRADAÇÃO AMBIENTAL GLOBAL - SITUAÇÃO ATUAL E ANÁLISE DAS POSSÍVEIS AÇÕES DE MITIGAÇÃO
}

\author{
Wagner Luís Andreassa
}

\section{RESUMO}

Esse trabalho mostra através de gráficos, tabelas, exemplos e análises, que a origem do fenômeno do aquecimento global (uso intensivo de energia) e o déficit social global é o incentivo para a demanda de produto e serviços que, de fato, não são necessários para uma vida digna e satisfatória da humanidade (consumismo). É observado que os benefícios desses produtos e serviços vão para uma parte mais privilegiada da população mundial, aumentando cada vez mais o abismo que separa a população mais favorecida da grande maioria das pessoas pobres e que, muitas vezes, não fazem uso de o mínimo necessário par prover sua subsistência. Esse trabalho tem a intenção de estimular o debate com vista a uma nova sociedade e para mostrar que um novo e simples estilo de vida deve ser considerado para resolver o problema do aquecimento global, as diferenças sociais e os sérios problemas de exaustão de recursos naturais da Terra. 


\title{
THE CONSUMERISM AS A RELEVANCE COMPOMENT IN GLOBAL ENVIRONMENTAL DEGRADATION - CURRENT SITUATION AND ANALYSIS OF POSSIBLE ACTION OF MITIGATION.
}

\author{
Wagner Luís Andreassa
}

\begin{abstract}
This work shows by means of graphs, tables, examples and analyses, that the origin of the phenomenon of the global warming (intensive energy use), and the global social deficit, is the incentive for the demand of products and services that, in fact, are not necessary to a dignity and worthy life of the humanity (consumerism). It is observed that the benefits for these products and services, go to a lowermost part of the world-wide population, widening each time more the abyss that separates the supplied populations of the great majority of the poor persons and that, in not rare times, do not make use of the minimum for the proper survival. In this direction, this work has the intention to stimulate a debate aiming a new society and to show that a new and a simple life style has to be consider to solve the global warming problem and the social inequalities and moreover, the serious problem of the exhaustion of the earth natural resource.
\end{abstract}




\section{SUMÁRIO}

Página

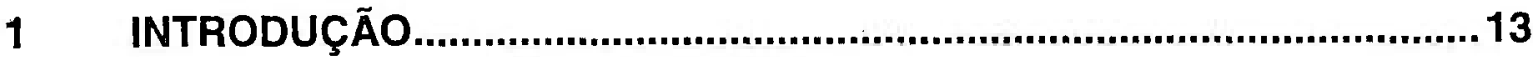

2 OBJETIVO

3 METODOLOGIA ......................................................................................... 16

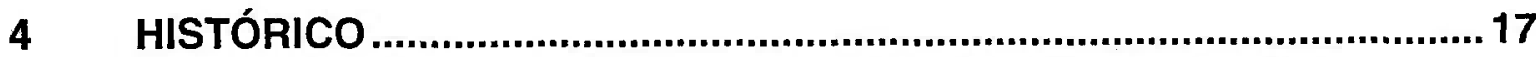

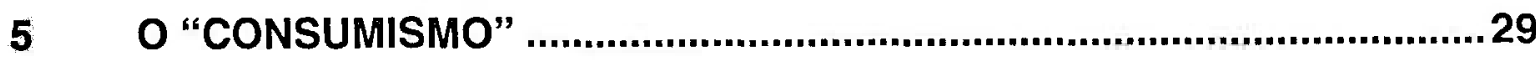

6 CONSUMO, MEIO AMBIENTE E SOCIEDADE.........................................37

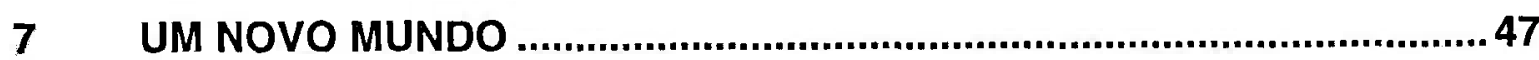

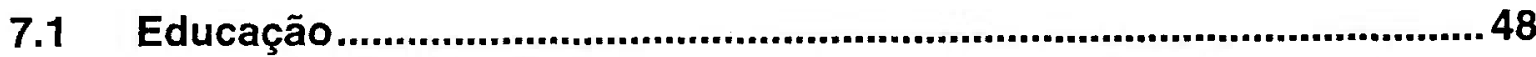

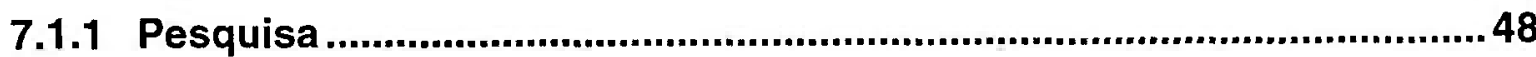

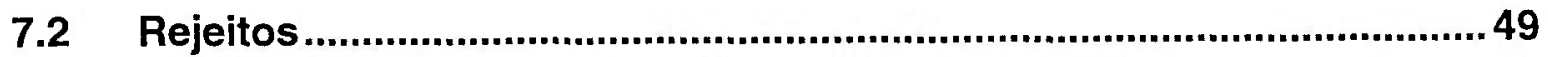

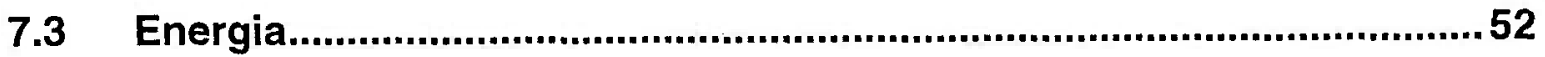

7.3.1 Tecnologias de produção de energia......................................................52

7.3.1.1 Caso da Islândia ..............................................................................56

7.3.1.2 Caso da Alemanha..........................................................................5

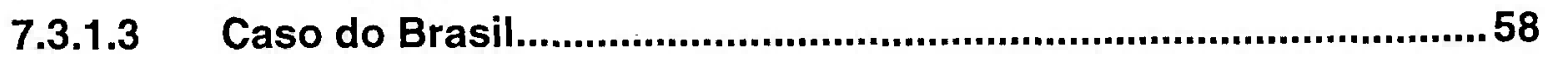

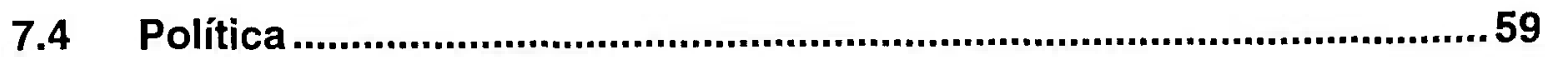

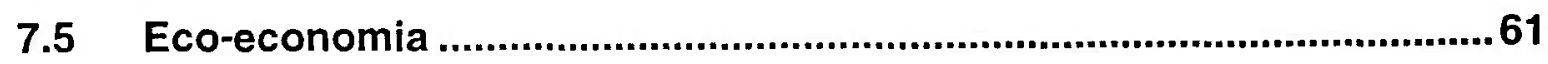

7.5.1 Imposto Internacional Para o Desenvolvimento ....................................63

7.5.2 Redução de emissões e Certificação Verde ...........................................64

7.5.3 Acondicionamento de produtos (embalagens) ....................................65

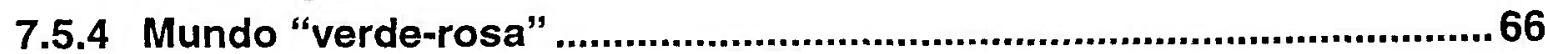


7.5.5 Novos Paradigmas da sociedade moderna......................................67

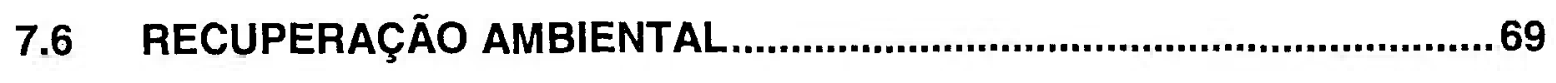

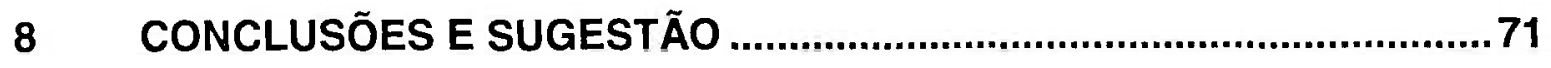

ANEXO A - Histórico dos eventos chaves que despertaram a atenção para as questões sócio/ambientais globais (1960 a 2007). ..........................76

ANEXO B - Índices utilizados no Trabalho ............................................90

ANEXO C - Externalidades ................................................................. 100

REFERÊNCIAS BIBLIOGRÁFICAS ....................................................... 103 


\section{LISTA DE TABELAS}

TABELA 1 - Consumo de carvão para algumas economias européias. ...............21

TABELA 2 - Percentuais de crescimento da população durante os primeiros 100

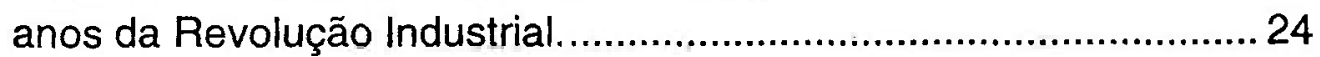

TABELA 3 - Gasto Anual em Itens de Luxo Comparado com os Recursos Necessários para o Atendimento de Necessidades Básicas ............. 33

TABELA 4 - Produção anual de lixo de alguns países selecionados.................... 41

TABELA 5 - Comparação entre os modelos Prius e Corolla................................. 56

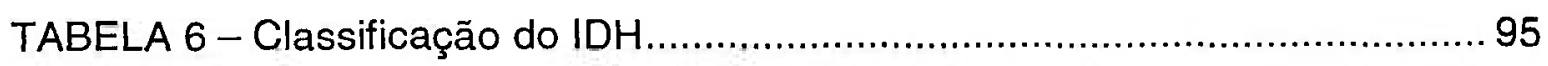




\section{LISTA DE FIGURAS}

FIGURA 1 - Transições energéticas mundiais em termos percentuais ..............21

FIGURA 2 - Evolução demográfica mundial ....................................................... 23

FIGURA 3 - Expansão da eletrificação nos EUA no início do século XX ........... 25

FIGURA 4 - Transição do modo de movimentação de pessoas (1840-2000)...... 26

FIGURA 5 - Tempo de massificação das mídias .............................................. 27

FIGURA 6 - Evolução temporal do PIB (produto interno bruto) mundial e da população na segunda metade do século XX ............................. 28

FIGURA 7 - Pirâmide de Maslow..................................................................... 29

FIGURA 8 - Proporção entre consumidores e não consumidores ........................ 31

FIGURA 9 - Evolução da Pressão Ecológica Global . ......................................... 34

FIGURA 10 - Participação de cada tipo de combustivel na matriz energética mundial (Energia Primaria - 2005) ............................................ 35

FIGURA 11 - Contribuição dos Vários Setores para o Efeito Estufa .................. 37

FIGURA 12 - Índice Planeta Vivo 1970 - 2005 ............................................... 38

FIGURA 13 - Índice de Sustentabilidade Ambiental x IDH . ...............................39

FIGURA 14 - Depósito de pneus usados a céu aberto nos EUA [48] ................. 42

FIGURA 15 - PIB/Capita versus IDH das nações para algumas economias ..... 43

FIGURA 16 - Pegada ecológica em diferentes niveis de IDH.............................. 44

-FIGURA-17-Giclo-de vida-de produtos com-a política de "berço a berço" ......... 50

FIGURA 18 - Formas de geração energia elétrica mundial. ................................ 53

FIGURA 19 - Variações de emissões pela adição de biodiesel ao diesel ........... 58

FIGURA 20 - Foto ilustrativa sobre poluição no mundo ……..............................6 60

FIGURA 21 - Sobre o problema de poluição na cidade de Beijin e como isso prejudicará a realização da maratona nas olimpíadas de $2006 \quad \ldots 61$

FIGURA 22 - Variação nas emoções em função do número de escolhas .......... 68

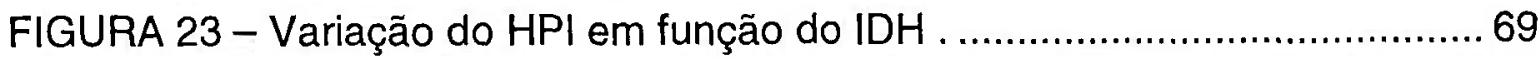

FIGURA 24 - Evolução da "Pegada Ecológica" por componente, 1961-2003 . ... 92

FIGURA 25 - Evolução da "Pegada Ecológica" por grupo de rendimento nacional

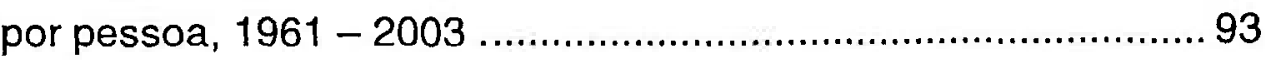

FIGURA 26 - Comparação Renda/capita e IDH entre Chile e Bahrein ................. 94 
FIGURA 27 - Comparação entre Egito e Namíbia, renda e IDH......................... 95

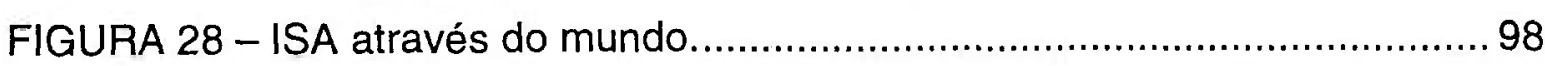

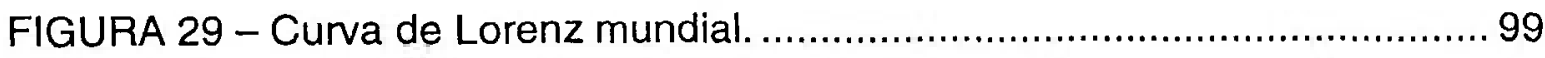

FIGURA 30 - Equilíbrio de mercado na ausência de externalidades ................ 100

FIGURA 31 - Equilíbrio de mercado na presença de externalidades positivas .. 101 FIGURA 32 - Equilíbrio de mercado na presença de externalidades negativas. 102 


\section{LISTA DE SIGLAS E/OU ABREVIATURAS}

AMBEV - Companhia de Bebidas das Américas

BNDS - Banco Nacional de Desenvolvimento Social

ESI - Environmental Sustainability Índex (Índice de Sustentabilidade Ambiental)

FP - Footprint Ecological (Pegada Ecológica)

G8 - Grupo dos 7 países mais ricos do mundo mais a Rússia

GEE - Gás de Efeito Estufa

IDH - Índice do Desenvolvimento Humano

IEA - Internatioinal Energy Agency (Agência Internacional de Energia)

IG - Índice Gini

IPCC - Intergovernmental Panel on Climate Change (Painel Intergovernamental de Mudanças Climáticas)

MDL - Mecanismo de Desenvolvimento Limpo

OCDE - Organização para a Cooperação e Desenvolvimento Econômico

OMS - Organização Mundial da Saúde

ONGs - Organizações Não Governamentais

ONU - Organização das Nações Unidas (UN - United Nations)

PIB - Produto Interno Bruto

PNUD - Programa das Nações Unidas para o Desenvolvimento

PNUMA - Programa das Nações Unidas para o Meio Ambiente

PPP - Purchasing Power Parity (Paridade de Poder de Compra)

RCE - Redução Certificada de Emissões

Toe - Tonelada de Óleo Equivalente

WWF - World Wildlife Fund 


\section{INTRODUÇÃO}

Ao longo dos tempos, problemas ambientais sempre foram tratados de forma pontual e isolada e, de fato, nunca despertou grandes interesses ou preocupações como nas últimas três ou quatro décadas. Isso porque só agora esses problemas estão mais presentes e visiveis, causando danos pessoais dos mais variados, perdas econômicas regionais e preocupações globais quanto ao próprio futuro do homem. Esses problemas foram surgindo num crescente a ponto de, num determinado momento, mobilizar pessoas das mais variadas áreas e formações para determinadas ações. Vem daí as primeiras conferências mundiais sobre meio ambiente $[1,2,3,4,5]$, criação de órgãos internacionais $[6,7,8]$, o surgimento de 'Organizações Não governamentais' específicas (as chamadas ONGs) $[9,10,11]$, a criação de órgãos de Meio Ambiente dentro da estrutura de poder dos estados (ministérios, secretarias, etc.), além do surgimento de legislações específicas, a inclusão do tema nos currículos escolares, etc. Enfim criou-se uma complexa estrutura social de conscientização, estudos, legislações e ações que envolvem praticamente todas as comunidades, nos mais variados estágios de atuação e conhecimento.

Apesar de todo o empenho por parte das muitas pessoas envolvidas nos mais diferentes organismos e órgãos, os impactos das ações antrópicas estão cada vez mais evidentes tais como: aumento do número de inundações, tufões e furacões, inclusive no Atlântico Sul, isso apenas para citar algumas das tragédias que foram causadas pelo chamado Aquecimento Global.

O Aquecimento Global é conseqüência do aumento da concentração de gases, como o dióxido de carbono $\left(\mathrm{CO}_{2}\right)$, na atmosfera. Esses gases são subprodutos indesejáveis de vários processos de produção. O que equivale a dizer que quanto mais aumenta o consumo (mantendo-se os atuais padrões de produção) mais aumentam as emissões de $\mathrm{CO}_{2}$ (por exemplo) na atmosfera e, conseqüentemente, aumentam as médias das temperaturas globais. Apesar dos 
inúmeros alertas, as concentrações de gases estufa vêm continuamente aumentando.

Por outro lado, existem diferenças enormes entre as diversas nações do mundo que fazem com que uma grande parte da população seja privada de um mínimo de consumo para a sua própria sobrevivência. A outra parte, apesar de ter esse mínimo, é impelida a sempre consumir mais. A economia mundial, hoje baseada fundamentalmente no capitalismo, é impelida a um crescimento sempre positivo e com isso um grande número de pessoas passam a consumir cada vez mais, porém, com os atuais meios de produção, isso implica em aumento constante das emissões de gases que causam o chamado Efeito Estufa.

Pode-se perceber que este impasse tem uma solução bastante complexa, pois envolve grande vontade política, inovação constante para a criação de novos produtos e, sobretudo, uma forma de produção de energia mais limpa, (a energia responde por mais de 50\% dessas emissões) [12].

Os países, no entanto, estão tentando se organizar para deter as emissões de gases estufa $[4,5]$, contudo os resultados ainda são pequenos. Os dois maiores emissores de $\mathrm{CO}_{2}$ do mundo, EUA e China, porém, não assinaram ainda o tratado de controle de emissões de gases efeito estufa (Protocolo de Quioto) [13].

De acordo com o jornal Folha de São Paulo [14], baseado nas previsões da Agencia Internacional de Energia (IEA na sigla em inglês) "carvão mineral, o combustível mais "sujo", terá maior crescimento na demanda". Segundo o mesmo artigo, o relatório da IEA, divulga que seriam necessários cortes de 19 bilhões de toneladas de $\mathrm{CO}_{2}$ para que o planeta fique em situação segura, porém a previsão é sombria, pois estima-se um aumento de $55 \%$ nas emissões de $\mathrm{CO}_{2}$ até 2030.

Ações, que visem melhorar a "qualidade" do desenvolvimento deverão ser adotadas pela maioria dos paises, seja qual for seu estagio de desenvolvimento. Estas ações são o que o presente trabalho pretende identificar. Algumas dessas ações são viáveis em curto prazo e outras em longo prazo, porém adianta-se que algo efetivo deve ser feito, pois disso dependerá o futuro da humanidade. 


\section{OBJETIVO}

Este trabalho tem como principal objetivo explorar as relações entre consumo, degradação ambiental e globalização (econômica e cultural) em uma seqüência histórica lógica, de modo a obter uma clara compreensão desse processo mundial que deverá ser, em algum momento, num futuro próximo, rompido dando lugar a uma economia que permita o surgimento de uma sociedade global sustentável (no sentido econômico e ambiental) e mais igualitária, onde as particularidades culturais também sejam respeitadas.

Novas e tradicionais propostas de ação deverão também ser analisadas num contexto global, regional e também pessoal - uma vez que estas ações envolverão necessariamente mudanças de hábitos tradicionais. Contudo, a análise dessas propostas não pretende, e nem poderia, ser exaustiva, pois cada uma delas, de um modo geral, são extensas e complexas e individualmente poderia ser um tema de pesquisa. 


\section{METODOLOGIA}

A metodologia adotada para o desenvolvimento do trabalho estará calcada principalmente na análise crítica e comparações quantitativas. Quando eventualmente isso não for possível, as análises se farão também de forma qualitativas. A base de informações será a literatura produzida mundialmente sobre os temas pertinentes. Atenção especial está sendo tomada no sentido de bem selecionar essa literatura, pois, na pesquisa bibliográfica preliminar na qual foi baseado o plano de pesquisa, surgiram muitas fontes sem o necessário rigor científico. 


\section{HISTÓRICO}

O homem, desde os primórdios de sua história, vem influenciando o meio em que vive de diversas formas, porém só após a chamada Revolução Industrial, em meados do século XVIII, essas influências tornaram-se muito mais acentuadas [15].

A Revolução Industrial caracterizou-se pela mecanização da produção e pela substituição da energia humana e animal por uma nova força motriz. Foi, de fato, a primeira vez na história da humanidade que uma força seria utilizada independentemente de condições climáticas e sem a utilização de animais. $\mathrm{Na}$ esteira dessa transformação tecnológica, outra grande transformação se seguiu e se revelaria muito maior do que se poderia prever na época: a transformação social [15].

Esse momento histórico de transformação já se processava na Europa, de modo ainda insipiente, desde a Baixa Idade Média. Ele se deu inicialmente nos países onde houve a Reforma Protestante, com particular destaque para a Inglaterra, principalmente pelo fato da separação da ciência e religião. Em outros países onde não houve a tal processo, a Revolução Industrial surge mais tarde como um esforço declarado de alcançar os paises mais avançados tecnologicamente.

Revolução Industrial foi um processo desencadeado por vários acontecimentos. Destaca-se, entre outros, o avanço nas ciências durante o período chamado de lluminismo associado às Reformas Protestantes que ocorreram no continente europeu.

A Inglaterra foi o palco inicial da Revolução Industrial, pois reunia muitos dos "ingredientes" que contribuiriam para esse fenômeno, entre eles, pode-se citar:

- O aumento da produção agrícola,

- A mudança do sistema de campos abertos para campos fechados (Enclauses Acts),

- O êxodo rural provocado pelas mudanças no campo, 
- O grande capital disponível, advindo do comércio marítimo,

- A necessidade de aumentar a produção, principalmente de tecidos, para suprir os novos mercados que surgiam.

Para Canedo [16], as intervenções do governo inglês na área rural, contribuíram decisivamente para que a Inglaterra fosse o primeiro país a realizar sua Revolução Industrial, entretanto, existem outras formas de analisar o processo de industrialização inglês, entre elas destaca-se a teoria dos Ciclos de Desenvolvimento [17].

A teoria dos ciclos de desenvolvimento é um entre os inúmeros tratados que tentam explicar o processo de evolução econômica e industrial mundial. Destaca-se, porém aqui dois autores: Karl Marx e Joseph A. Schumpeter. Ambos os autores tem teorias sobre o desenvolvimento econômico, ambos acreditam que isso é cíclico, porém dão diferentes abordagens ao mesmo fato [17].

Para a corrente Marxista, o crescimento tem como principal característica, o acúmulo de capital, o que pode se observar no texto a seguir:

"Para os maxxistas, as ondas longas são períodos históricos irregulares de acumulação de capitais intimamente relacionados com mudanças significativas na taxa de lucro média. $O$ início de uma fase de prosperidade corresponde a movimentos sincrônicos de aumento da taxa de mais-valia, menor elevação da composição orgânica do capital e aceleração da rotação do capital. Quando há combinação de pelo menos dois desses três fenômenos, a tendência geral à queda da taxa de lucro média é fortemente contrariada, gerando um firme período de expansão" [17].

Percebe-se que no texto destaca-se o acúmulo de capitais e aumento de taxa de mais valia (lucro obtido por produção em escala), não dando nenhuma ênfase no fator de inovação tecnológica.

Joseph A. Schumpeter (1883 - 1950), outro brilhante economista que realizou estudos sobre desenvolvimento e seus desencadeadores incluiu no cenário econômico o avanço tecnológico como um dos fatores do crescimento, que para ele era o principal fator. Como é descrito por Costa [18].

“1) Introdução de um novo bem, ou seja um bem com que os consumidores ainda não estejam familiarizados. Ou de uma nova qualidade de um bem. 
2) Introdução de um novo método de produção, ou seja, um método que ainda não tenha sido testado pela experiência no ramo próprio da indústria de transformação, que, de modo algum, precisa ser baseado numa descoberta cientificamente nova, e pode consistir também em nova maneira de manejar comercialmente uma mercadoria.

3) Abertura de um novo mercado, ou seja, de um mercado em que o ramo particular da indústria de transformação do país em questão não tenha ainda entrado, quer esse mercado tenha existido antes ou não.

4) Conquista de uma nova fonte de matérias-primas ou de bens semi-manufaturados, mais uma vez independentemente do fato de que essa fonte já existia ou teve que ser criada.

5) "Estabelecimento de uma nova organização de qualquer indústria, como a criação de uma posição de monopólio (por exemplo, pela trustificação) ou a fragmentação de uma posição de monopólio" [18].

Pode-se perceber que nas considerações de Shumpeter, o grande estaque é o empreendedor de tecnologia, pois este acredita que um novo produto ou uma nova forma de produção possa gerar riqueza com mais intensidade, pois com um produto ou meio de produção novos aumenta-se muito o lucro. Essa corrente não vê o capital como o principal fator para o impulso de um novo ciclo de desenvolvimento.

Levando-se em consideração o exposto, percebe -se que a Inglaterra reunia as três condições, acúmulo de capital, inovação tecnológica e empreendedores para iniciar os processos. A reunião de tantos fatores a favor desencadeou um intenso e contínuo processo de industrialização e prosperidade na Inglaterra.

A força hidráulica foi a principal força motriz dos primeiros anos da Revolução Industrial, o que concentrou as unidades fabris as margens dos rios ingleses. Porém a força hidráulica logo foi substituida pela força a vapor em uma máquina aperfeiçoada pelo operário inglês James Watt em 1765. As máquinas a vapor tinham muitas utilidades, tais como bombear água e movimentar teares mecânicos. Por conta dessas máquinas, a Inglaterra se tornou a maior exportadora mundial de tecidos. Nas primeiras décadas do século XIX, as máquinas a vapor já equiparam também navios e locomotivas [19].

O desenvolvimento da força a vapor sinalizou um novo tempo, pois pela primeira vez na história estava disponível uma força mecânica que não tinha 
origem em animais, vento ou movimento das águas, independente de condições climáticas ou da vontade humana de trabalhar. A constância é a outra grande vantagem que a força a vapor disponibiliza para a produção.

Com isso os complexos fabris ganharam independência e puderam se instalar em qualquer lugar, não precisando situar-se ao lado dos leitos dos rios para usarem a força hidráulica.

A indústria têxtil e a siderúrgia foram as grandes alavancas para 0 desenvolvimento industrial inglês [19]. As novas tecnologias e arranjos produtivos conseguiam fazer tecidos muito mais baratos e em maior quantidade, o que facilitava a entrada em mercados já consolidados ou mesmo nos mercados em formação, além de tornar impossível outro país tentar entrar no mercado inglês.

O vapor teve especial importância nesse cenário, mas apesar de suas inegáveis vantagens, tinha o inconveniente de necessitar de grande quantidade de combustível, que num primeiro momento veio da madeira, que já nos primeiros anos do século XIX se esgotou com o aniquilamento das florestas inglesas [19], sendo substituída então pelo carvão mineral. Esse desmatamento foi o primeiro grande impacto ambiental trazido pela Revolução Industrial. Outra conseqüência ambiental importante, no começo da era industrial, foi o grande número de baleias mortas, cujo óleo era usado tanto para lubrificação das máquinas como na iluminação das fábricas.

O carvão passou então a ser o mais importante insumo para o desenvolvimento industrial de uma nação. Seu consumo aumentou muito tornando-se a principal fonte de energia do século $X I X$ e princípio do século $X X$. $A$ TAB.1 a seguir mostra a evolução no consumo de carvão de alguns países europeus, em meados do século $X I X$ e no início do século XX. Na FIG.1 são mostradas as transições energéticas desde 1850 até o fim do século $X X$. 
TABELA 1 - Consumo de carvão para algumas economias européias [15].

\begin{tabular}{c|c|c}
\hline Pais & $\begin{array}{c}1861 \\
\text { Milhões de toneladas } \\
\text { métricas TM }\end{array}$ & $\begin{array}{c}1913 \\
\text { Milhões de toneladas } \\
\text { métricas TM }\end{array}$ \\
\hline Reino Unido & 77.657 & 189.074 \\
\hline Alemanha & 13.957 & 187.000 \\
\hline França & 15.403 & 64834 \\
\hline Bélgica & 6.140 & 26.032 \\
\hline
\end{tabular}

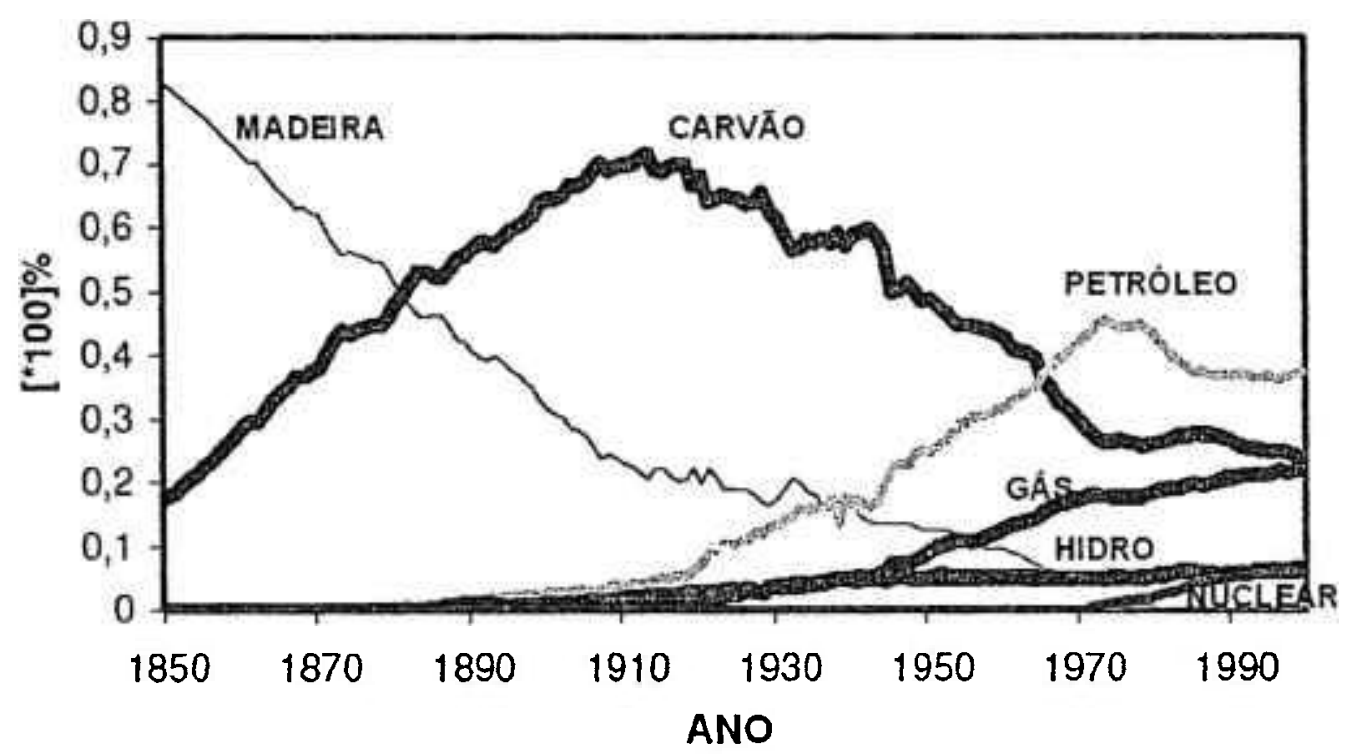

FIGURA 1 - Transições energéticas mundiais em termos percentuais [20].

O carvão impulsionou todos os ramos da indústria, mas o principal avanço foi na área de siderurgia, pelo envolvimento como matéria prima e não somente como combustivel para os fornos e máquinas. Na seqüência, ganhou espaço na área de transportes com a criação das primeiras estradas de ferro e mais tarde com os navios movidos a vapor, possibilitando assim transportes de cargas e passageiros de forma mais rápida, segura e barata. A contribuição da força do vapor para a expansão da economia inglesa foi muito grande como destaca Lands [15] em seu comentário: 
"[...] 1870. Neste ano a capacidade das máquinas a vapor na GrãBretanha era de cerca de 4 milhões de cavalos-vapor, equivalente a 6 milhões de cavalos ou 40 milhões de homens. Se (presumíssemos) os mesmos padrões de consumo alimentar do século XVIII, esse número de homens teria inserido cerca de 320 milhões de alqueires de trigo por ano - mais de três vezes a produção anual do todo Reino Unido entre 1867 e 18 71" [15].

Equivalente, portanto, a um exército de trabalhadores incansáveis com infimos salários. Isso fez da Inglaterra a principal economia do século XIX. Estima-se que entre 1840 a 1880 a potência total em máquinas de vapor cresceu de 2 para 28 milhões de HP no mundo, a maior parte na Inglaterra.

A população que era essencialmente rural intensificou a migração para as cidades para trabalhar nas fábricas recém criadas. As cidades, na maioria das vezes, não tinham estruturas para receber tal contingente de trabalhadores. Os trabalhadores, por sua vez, começaram a se organizar em grupos, dando início aos sindicatos e as discussões de questões sociais. É nessa época que surgem as doutrinas políticas liberais como a Fisiocracia (Quesnay) [19] e o Liberalismo Econômico (Adam Smith) [21] e, na seqüência, seus contrapontos: o Socialismo Científico (Marx e Engles) [22] e o Anarquismo (Bakunin e Kropotkin) [23]. Grandes pólos industriais surgiram, e com eles os conflitos, provocados principalmente por baixos salários e condições de trabalho precárias [15].

Apesar das condições de trabalho dos trabalhadores ingleses não ser a ideal, de certa forma houve um ganho em comparação as outras nações que tardaram a realizar a sua Revolução Industrial, como observa Philip [24].

"o trabalhador inglês não apenas comia melhor; ele gastava menos dinheiro com comida dos que seus semelhantes na Europa continental e na maioria dos outros lugares, esse gasto diminuía, enquanto do outro lado da Mancha é bem possivel que tenha aumentado durante grande parte do século XVIII. Portanto, possuia uma reserva maior para gastar com outras coisas, inclusive produtos manufaturados" [24].

As populações das cidades cresceram de forma desordenada. Este fato contribuiu para o agravamento dos problemas sociais, mesmo para os 
ingleses que eram melhores remunerados. A condição de vida nas cidades era, em geral, bastante precária.

Porém esse foi o início de um período de crescimento populacional intenso e sem precedentes na história da humanidade (FIG. 2). Isso devido a dois principais fatores: aumento da taxa de natalidade e aumento da expectativa de vida da população. Este último devido ao próprio desenvolvimento da ciência.

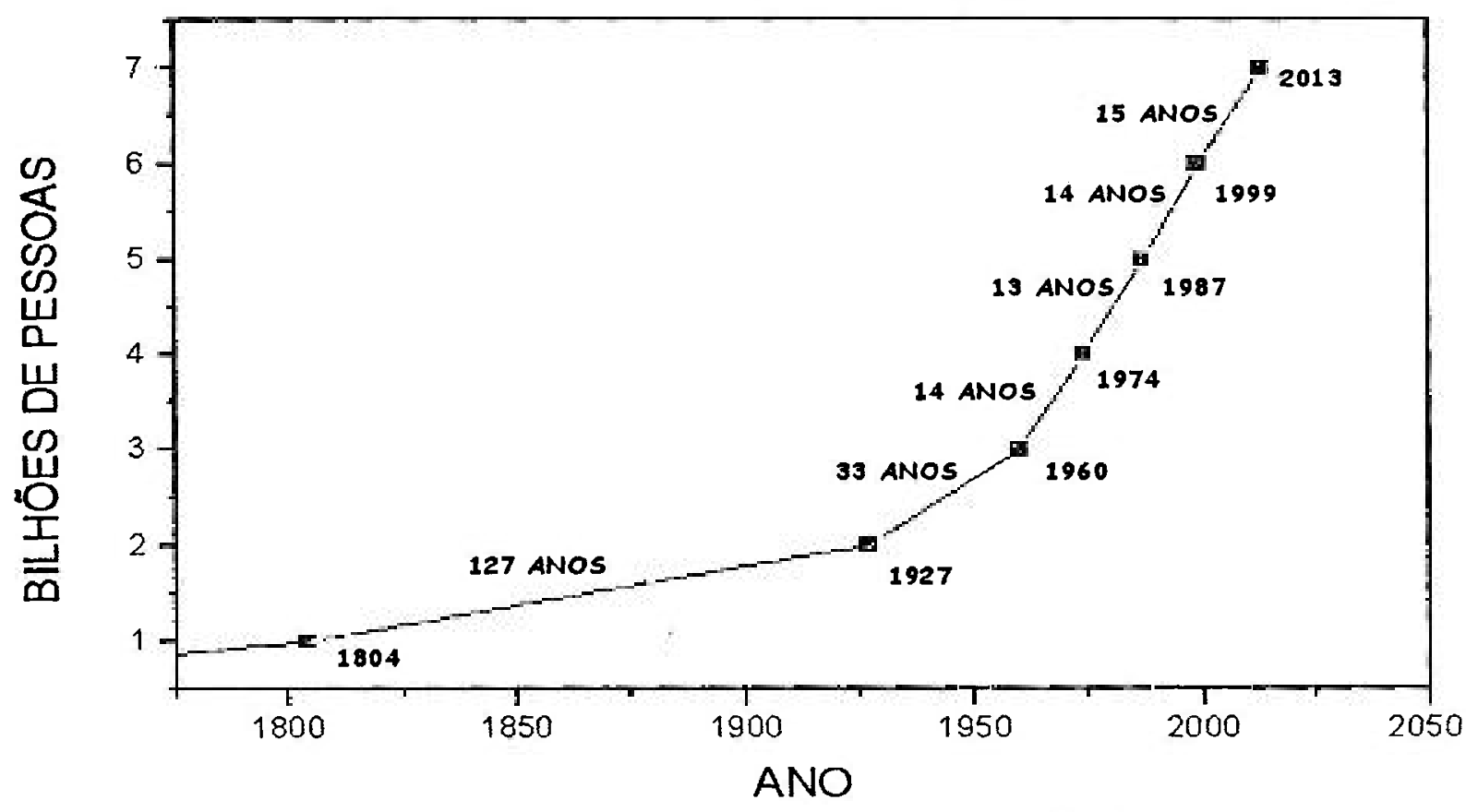

FIGURA 2 - Evolução demográfica mundial

Fica evidente na FIG.2, que a partir da Revolução Industrial, iniciou-se um processo de crescimento populacional intenso, principalmente após a segunda metade do século XIX, criando assim um enorme mercado para os produtos industrializados.

Juntamente com o crescimento populacional, durante o primeiro século da Revolução Industrial, iniciou-se um processo de migração do continente Europeu para outros continentes [25], principalmente para as Américas, mudando decisivamente a distribuição de população pelo mundo (TAB.2). 
TABELA 2 - Percentuais de crescimento da população durante os primeiros 100 anos da Revolução Industrial.

\begin{tabular}{c|c|c}
\hline CONTINENTE & $1750-1800$ & $1800-1850$ \\
\hline EUROPA & $34 \%$ & $43 \%$ \\
\hline ÁSIA & $28,5 \%$ & $33 \%$ \\
\hline AMÉRICA DO NORTE & $145 \%$ & $300 \%$ \\
\hline AMÉRICA CENTRAL/SUL & $51 \%$ & $73 \%$ \\
\hline
\end{tabular}

Fonte Schner [26]

O crescimento da população mundial acrescentou, logicamente, muitos consumidores para os produtos industrializados que, como já visto, no começo teve pleno domínio dos ingleses. Porém a partir de 1870, estes começaram a sentir uma concorrência crescente o que, além de baratear os preços dos produtos industrializados, contribuiu para uma maior distribuição dos mesmos.

Os primeiros anos da Revolução Industrial, não foram anos tranqüilos. Mas, mesmo com baixos salários, os operários formaram uma classe consumidora, impulsionando assim, conjuntamente às exportações para outros continentes, a produção da época. [21].

No início do século $X X$ as transformações foram intensas, principalmente com o advento do motor elétrico, do motor a explosão interna, do telégrafo e da lâmpada incandescente. Apenas como ilustração, é mostrada na FIG.3 a evolução no consumo de energia elétrica residencial e industrial nos Estados Unidos no início do século XX. A criação da lâmpada elétrica em 1879 , provavelmente foi o acontecimento que mais impulsionou a energia elétrica, pois era uma aplicação prática que não existia, criando assim uma demanda. Seu inventor Thomas Edson criou um serviço de fornecimento de energia elétrica com 86 assinantes, em Nova York. Em 1879, na virada do século, já tinha mais de um milhão de clientes [27]. 


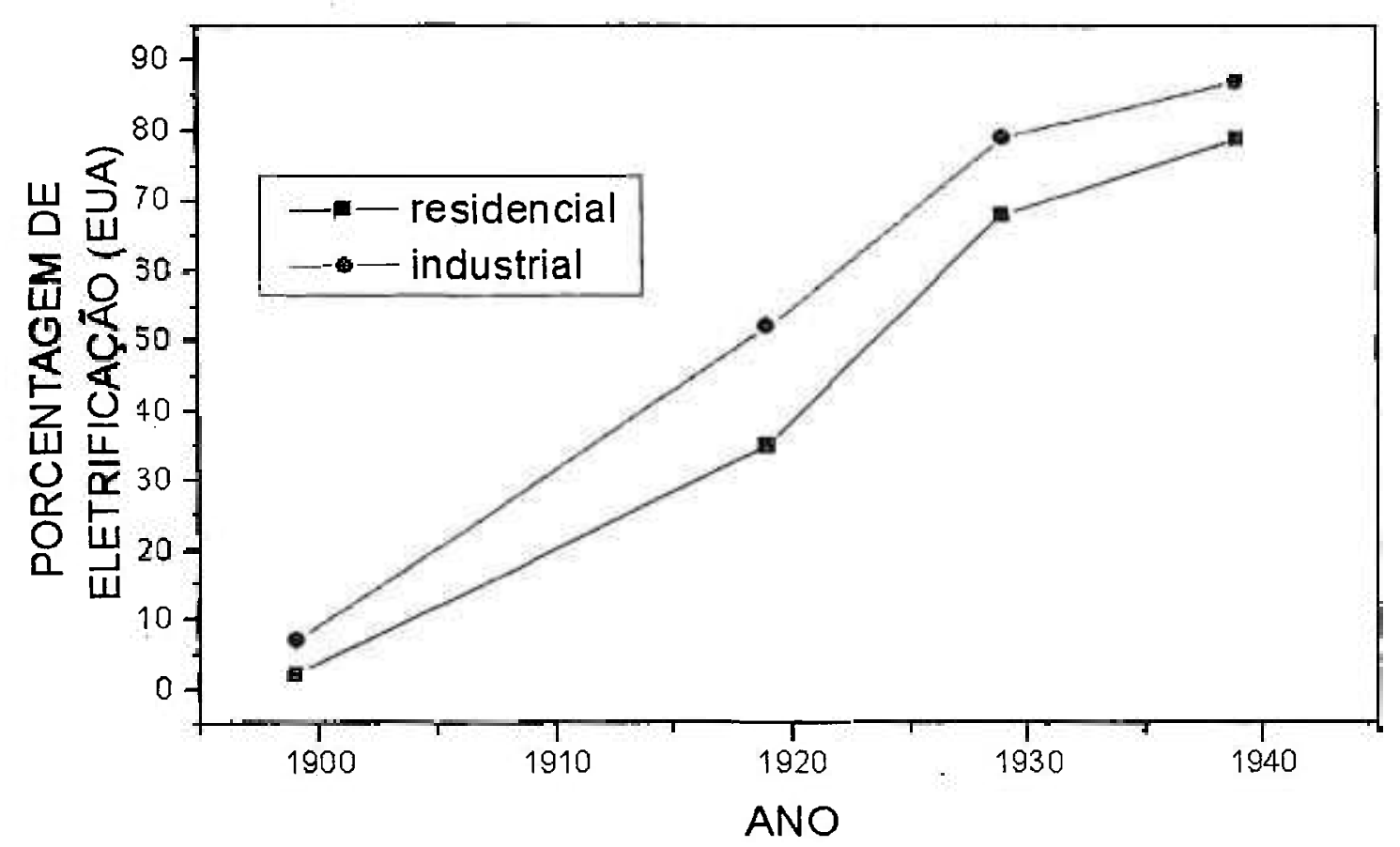

FIGURA 3 - Expansão da eletrificação nos EUA no início do século XX [28].

No início do século $\mathrm{XX}$, a indústria passou a utilizar o petróleo como principal energético e em pouco tempo o setor de transportes também aderiu ao petróleo, principalmente pela sua alta capacidade energética em função de seu volume.

Com a evolução da indústria em geral, destaca-se a automobilística, que com a adoção de automação da linha de montagem e uma política de redução de custos (Ford Motors dos EUA) foi possivel popularizar o automóvel na Europa e nos EUA, ainda nas primeiras décadas do século XX. Isso contribuiu fortemente para $o$ aumento do consumo de petróleo nessas regiões.

O automóvel deu grande mobilidade às pessoas. A FIG.4 mostra a grande transição que houve nos meios de locomoção das pessoas. Já no início do século $X X$, pode-se perceber o quanto o automóvel impactou a forma das pessoas se locomoverem. 


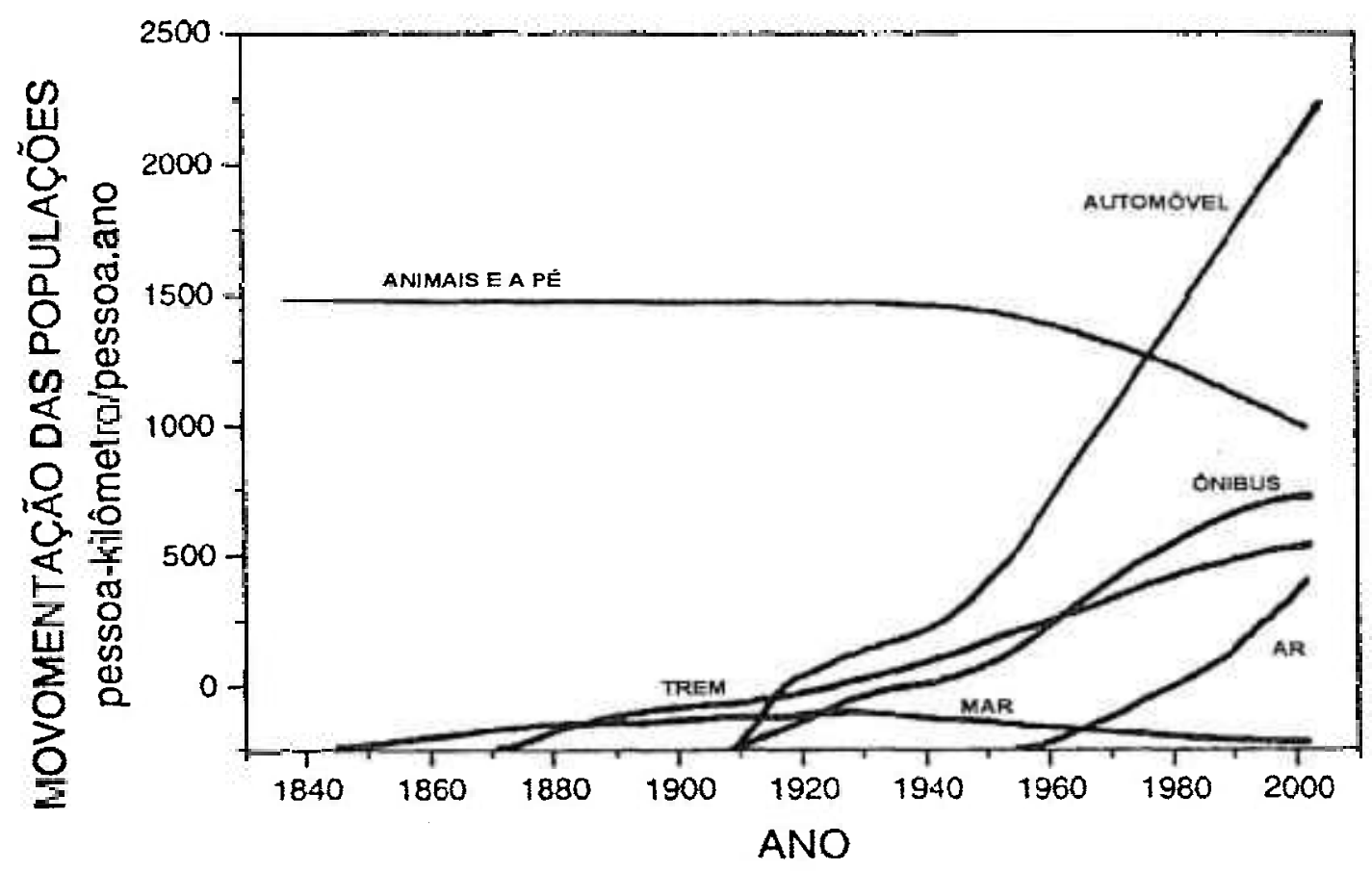

FIGURA 4 - Transição do modo de movimentação de pessoas (1840-2000) (Adaptado: Monteiro [29]).

Pode-se perceber que as formas de transportes mudaram muito em curto intervalo de tempo. Um fato que se deve levar em conta é que apesar de praticamente todos os meios de transportes coletivos crescerem, o transporte com automóveis cresceu de forma bem mais acentuada.

Com o grande número de carros circulando pelas ruas e a crescente demanda por energia elétrica, o petróleo cresceu e tornou-se a principal fonte de energia do século XX.

Embora o petróleo tivesse um crescimento substancial, o carvão continuou como força motriz importante (FIG. 1), sendo utilizado largamente até os dias atuais como combustível, principalmente para produção de energia elétrica [30].

Como já foi relatado, o início do século XX, foi marcado por várias grandes invenções, não apenas pelo automóvel. Especial destaque se dá aos meios de comunicação, especialmente o rádio, inventado por Marconi, que entre as décadas de 20 e 40, teve uma grande penetração na população no mundo inteiro, dando início à era das comunicações. Isso facilitou a divulgação e a incorporação de novos produtos no dia a dia das pessoas [31]. 
Surgem nesta época os primeiros conceitos de Marketing (Mercadologia), com a função de fazer com que os produtos tenham mais atrativos para os consumidores, ressaltando as qualidades e aplicações e em alguns casos mascarando os seus defeitos, tais como o impacto ambiental. Os profissionais de mercadologia têm muitas vezes influenciado diretamente o comportamento das pessoas ao longo do século XX e, em muitos casos, essa influencia apenas contribuiu para o crescimento de consumo de produtos que nenhum benefício trazem à sociedade, como é o caso dos fabricantes de cigarro. Este é apenas um exemplo de grandes conglomerados empresariais que pouca preocupação tiveram (e têm!) com a sociedade e o meio ambiente [32].

Outra particularidade dos constantes avanços tecnológicos é o tempo de massificação das tecnologias, como pode ser observado na FIG.4 com relação ao desenvolvimento das comunicações. A "comunicação de massa" têm forte influência no padrão de consumo da sociedade, seja ela local, regional ou mesmo mundial.

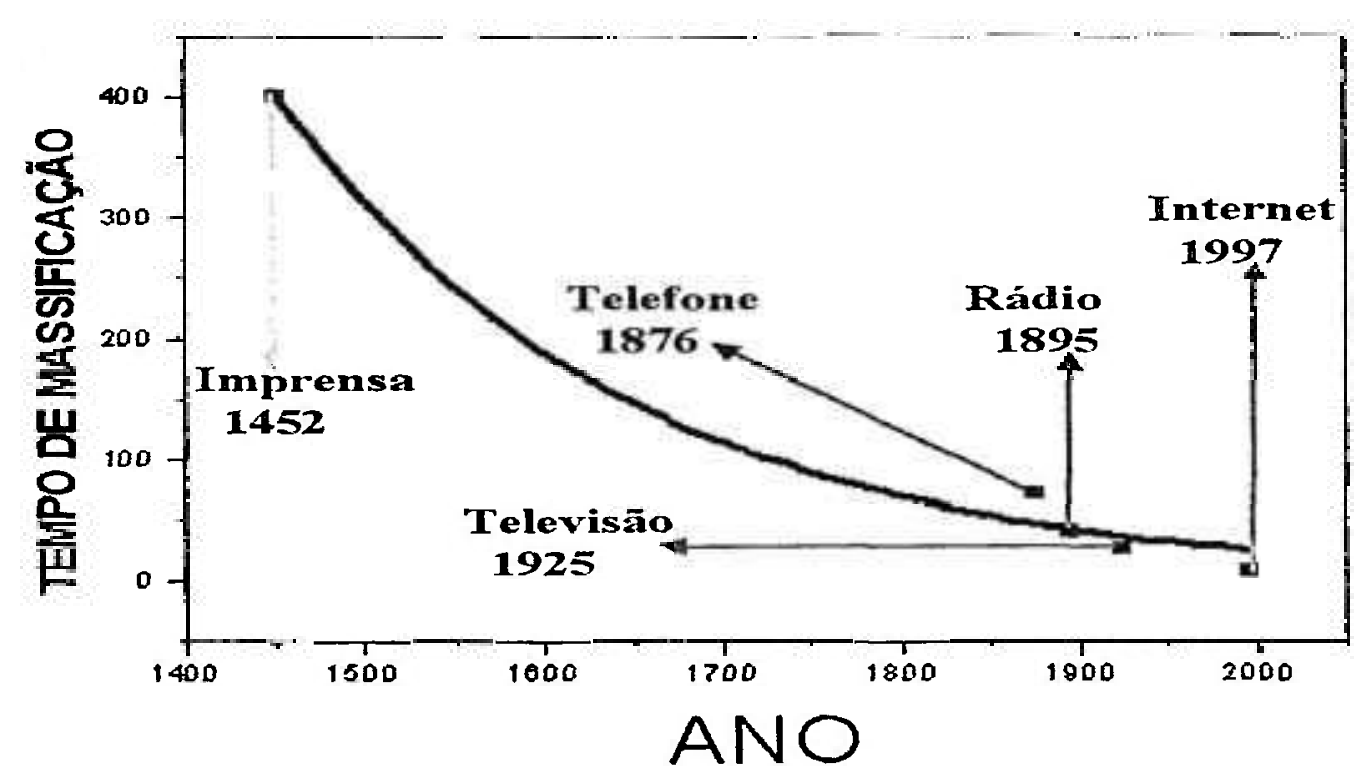

FIGURA 5 - Tempo de massificação das mídias

Esse processo revolucionário de aumento constante de produção e consumo se dá até os dias de hoje de modo crescente e contínuo.

A sociedade atual foi moldada para dar vazão a uma produção cada vez maior. $\mathrm{Na}$ atualidade, as pessoas vivem em um mundo muito complexo, no 
qual foram forjadas várias necessidades. A chamada globalização expõe as pessoas a produtos de diversas partes do mundo, esses produtos podem até contribuir para uma vida mais confortável [33], porém seus preços refletem apenas os custos de produção, transporte, impostos e intermediação, negligenciando o impacto sobre a natureza $e$ os custos secundários representados pelos efeitos colaterais, como a poluição e seu reflexo na saúde humana. A figura abaixo corrobora para uma visão de futuro que é insustentável, haja vista que esse fato se processa numa área fixa total de aproximadamente 510 milhões de $\mathrm{Km}^{2}$, dos quais 149 milhões são de terras firmes e 361 milhões são de água.

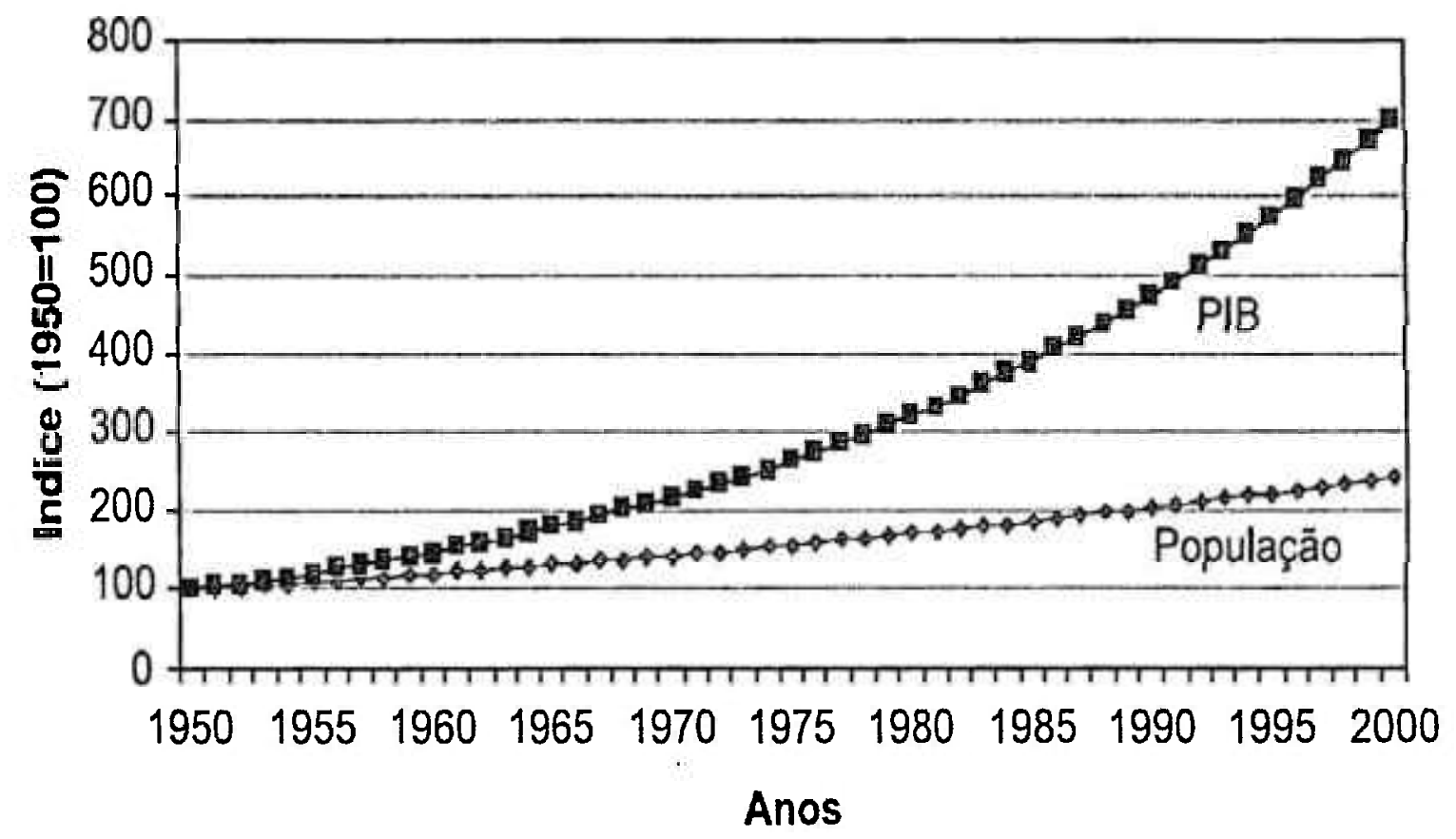

FIGURA 6 - Evolução temporal do PIB (produto interno bruto) mundial e da população na segunda metade do século $X X$.

Em contrapartida a essa sociedade consumista, surgem ao longo da segunda metade do século $X X$, movimentos que tentam equilibrar a sociedade, a economia e o meio ambiente (Anexo A), porém ainda não se chegou a uma espécie de consenso, que seja desencadeador de um processo global de mudanças no status quo geral atual. 


\section{O "CONSUMISMO"}

As pessoas possuem diversas necessidades, algumas mais importantes outras menos. Com o intuito de entender e melhor explicar essas necessidades, Abraham Maslow, psicólogo americano que estudou o comportamento humano, criou em meados do século $X X$, a chamada pirâmide de Maslow $[34,35]$. Observando os padrões pelos quais as pessoas se motivam, ele estabeleceu que a motivação estava intimamente ligada às necessidades. Criouse então uma escala de 5 níveis para classificar cada um desses niveis em ordem de prioridade, ou seja, criou-se uma hierarquia das necessidades.

As necessidades são classificadas por Maslow em: necessidades Fisiológicas; Segurança; Social; do Ego e Auto Realização. Para melhor visualizar como as necessidades se sucedem, estas foram colocadas em formato de pirâmide, que ficou conhecida então como pirâmide de Maslow, muito utilizada por diversas áreas do conhecimento. Na pirâmide de Maslow as 5 classificações das necessidades foram colocadas de baixo para cima por ordem de importância, quanto mais prioritária mais baixa na pirâmide.

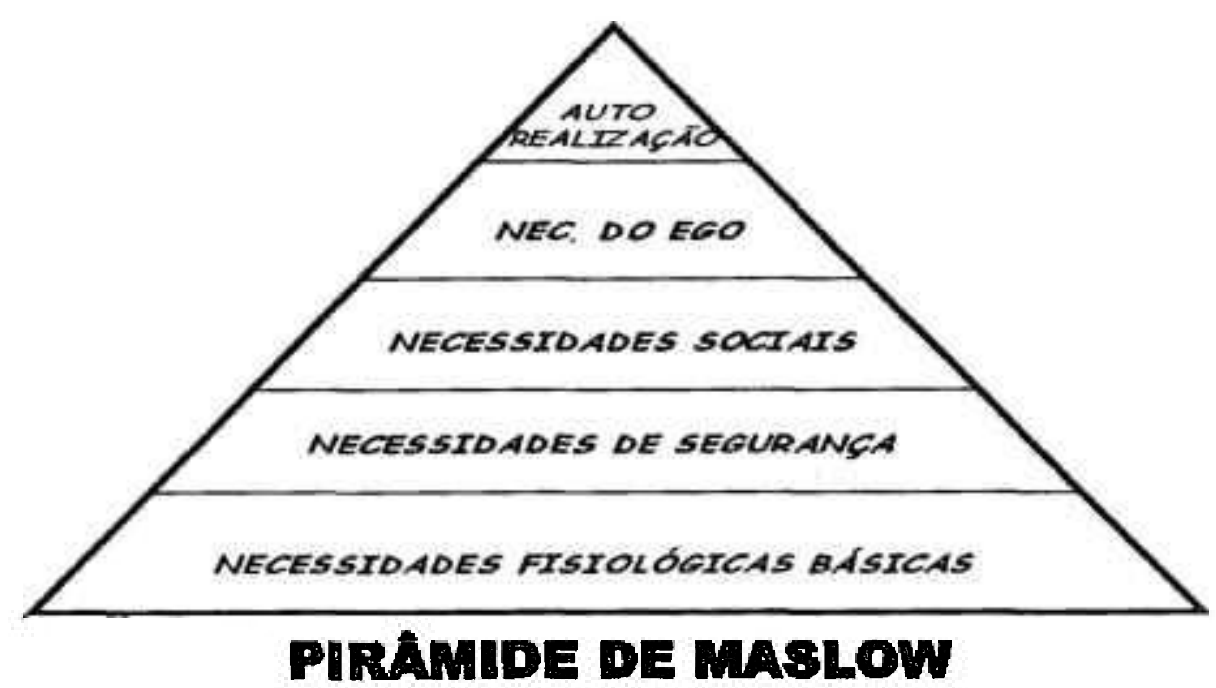

FIGURA 7 - Pirâmide de Maslow. 
As duas primeiras divisões da base da pirâmide estão presentes independentes da situação ou da época. As outras foram sendo agregadas e são de satisfação mais complexas. A percepção das necessidades de níveis mais altos depende do grau de satisfação das necessidades de níveis mais inferiores.

Em paises ou regiões onde a população tem dificuldade de até se alimentar, ou seja, a população que vive com menos de um dólar ao dia, as necessidades de altos níveis acabam desaparecendo, pois essa população precisa de alimentos e água (necessidades Fisiológicas) e de segurança, pois estão normalmente em áreas de conflito. Nessa situação os únicos produtos que motivam essa população ao consumo são os relacionados às duas primeiras dimensões da pirâmide.

Para a parcela da população mundial que não tem problemas em conseguir suprir suas necessidades básicas, estas acabam se "misturando". Muitas vezes o que é realmente importante fica em segundo plano, e o que é dispensável é dada muita prioridade. Esta situação gera, em muitos casos, inúmeros desperdícios, tais como: um automóvel com mais de duas toneladas, motor de 8 cilindros com mais de 350 cavalos de potência, consumo de $8 \mathrm{~km} / \mathrm{litro}$ de gasolina, para transportar uma pessoa em uma cidade grande, com média de velocidade de $60 \mathrm{Km} / \mathrm{h}$ [36]. Uma situação dessas, em muitos casos, apenas para satisfazer uma necessidade social que poderia ser suprida com outras atitudes.

A solicitação sempre crescente por bens e serviços, inclusive aqueles denominados aqui de intensivo, como a produção e consumo de energia, diz respeito à própria lógica do sistema capitalista em curso. A base de sustentação deste sistema econômico, que se constitui também (e ao mesmo tempo!) em sua causa e efeito, é o consumo. Como foi visto no capítulo anterior, esse modelo de sociedade teve seu início com a Revolução Industrial e hoje está disseminado por todo o globo. As formas de consumo mais exacerbadas são designadas, no neologismo corrente, de "consumismo".

$\mathrm{O}$ consumismo tem graves efeitos para a sociedade como um todo. $\mathrm{Na}$ atualidade um dos problemas mais graves de saúde pública são as doenças associadas à obesidade [37]. Em muitos países este é um problema maior que a desnutrição, pois atinge um contingente maior de pessoas. Apenas como exercício de lógica, a obesidade esta associada com uma alimentação abundante 
e desequilibrada, já a desnutrição esta associada, obviamente, a falta de alimentos. Conclui-se daí, também de maneira óbvia, que se os alimentos fossem mais bem distribuídos, se teria solucionado os dois problemas simultaneamente.

Segundo relatório divulgado pelo Instituto Worldwatch [36], "o consumismo desenfreado é a maior ameaça ao futuro da humanidade", não apenas pelo esgotamento dos recursos naturais disponiveis do planeta, mas também com a conseqüente deterioração da qualidade de vida das pessoas, notadamente as mais pobres. Este consumo, no entanto, é tremendamente desproporcional entre as economias. Para se ter uma idéia, o relatório mostra que existem cerca de 1,7 bilhões de pessoas (aproximadamente um quarto da humanidade) que integram a classe consumidora. São eles, a grosso modo, os que possuem renda familiar anual superior a US 7.000 e consomem televisores, telefones, internet e todos os bens, sejam eles de consumo ou culturais, que são comercializados através desses meios. O restante da humanidade mantém um nível de consumo não relevante, o que não quer dizer que o impacto ecológico causado por esses contingentes seja também irrelevante. Números específicos dão a dimensão exata das duas realidades antagônicas atuais (FIG.8).

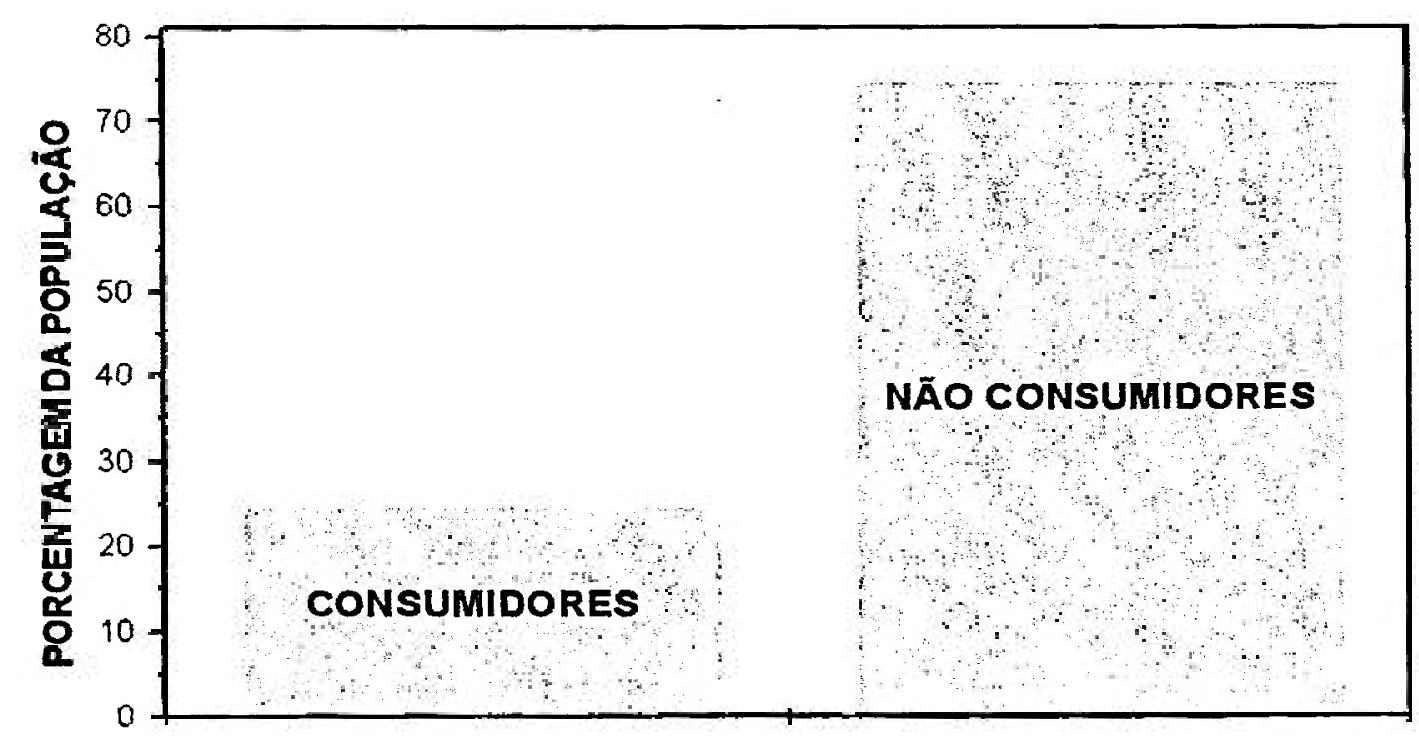

FIGURA 8 - Proporção entre consumidores e não consumidores.

Observa-se, pelo gráfico acima, a grande diferença entre o número de consumidores e os não consumidores. Caso uma parte significativa dos não consumidores consiga renda suficiente para tornarem-se consumidores, o 
crescimento de consumo total será enorme. Aliado a isso há de se considerar também o crescimento vegetativo da população. Será então muito difícil suprir todos esses novos consumidores com o mesmo padrão de consumo observado hoje, pois não existem recursos naturais para atender tal aumento de demanda de forma sustentável.

Para ilustrar a gravidade do problema, apenas o crescimento vegetativo da população mundial, mantendo-se a proporção de consumidores e não consumidores, em 10 anos os consumidores serão quase 2 milhões, o que pode levar à um grande impacto na produção mundial. O acréscimo de $20 \%$ nessa fatia da população significa um aumento muito maior no contexto geral, principalmente no que se refere ao consumo.

Como exemplo, o relatório do WWF [36] mostra que são gastos anualmente, entre produtos de maquiagem e perfumes, o dobro do necessário para eliminação da fome e da desnutrição no mundo e o gasto com sorvetes na Europa poderia proporcionar o fornecimento de água potável para todos os que dela necessitam.

A TAB.3, reproduzida do relatório "O estado do mundo" [36], produzido pela mesma instituição, mostra alguns exemplos das distorções do consumo no mundo.

Pode-se perceber, pela TAB.3, que caso a prioridade mundial fosse acabar com as desigualdades, haveria recursos para isso. Não há pretensões em fazer campanha contra os produtos da primeira coluna, nem lhes dar o título de vilões das desigualdades, apenas alertar que existem recursos que poderiam ser direcionados para objetivos mais globais e menos individuais.

Analisando as informações anteriores, percebe-se que existe um grande abismo entre a população "mais rica" e a "mais pobre". Esse abismo pode ser medido por um índice criado por Conrado Gini (1912), que segundo o PNUD:

"Mede o grau de desigualdade existente na distribuição de renda dos indivíduos segundo a renda domiciliar per capita. Seu valor varia de 0 (zero), quando não há desigualdade (a renda de todos os indivíduos tem o mesmo valor), a 1, quando a desigualdade é máxima (apenas um indivíduo detém toda a renda da sociedade e a renda de todos os outros indivíduos é nula)" [38] (Anexo B). 
TABELA 3 - Gasto Anual em Itens de Luxo Comparado com os Recursos Necessários para o Atendimento de Necessidades Básicas Selecionadas.

\begin{tabular}{c|c|l|c}
\hline $\begin{array}{c}\text { Produtos } \\
\text { Supérfluos }\end{array}$ & $\begin{array}{c}\text { Gasto } \\
\text { Anual } \\
\text { (bilhões } \\
\text { de US\$) }\end{array}$ & $\begin{array}{c}\text { Objetivo } \\
\text { Social/Econômico }\end{array}$ & $\begin{array}{c}\text { Investimento } \\
\text { Extra Anual } \\
\text { Necessário para } \\
\text { Atingir os } \\
\text { Objetivos } \\
\text { (bilhões de US\$) }\end{array}$ \\
\hline $\begin{array}{c}\text { Cosméticos } \\
\text { de Estimação } \\
\text { (EU/EUA) }\end{array}$ & 18 & $\begin{array}{l}\text { Saúde reprodutiva para } \\
\text { todas as mulheres }\end{array}$ & 12 \\
\hline Perfumes & 15 & $\begin{array}{l}\text { Erradicação da fome e } \\
\text { má nutrição }\end{array}$ & 19 \\
\hline $\begin{array}{c}\text { Cruzeiros } \\
\text { Marítimos }\end{array}$ & 14 & Água potável para todos & 10 \\
\hline Sorvetes na \\
Europa
\end{tabular}

Fonte: Estado do Mundo - 2004 (WWI - Worldwatch Institute) [36]

O índice Gini de cada pais é divulgado no mesmo relatório do IDH, apesar de não ser um de seus componentes. Tem grande relevância, pois junto com o IDH, permite traçar um perfil da sociedade que se está considerando.

Um grande desafio dos países em desenvolvimento é fazer melhorar esta relação entre os que têm grande poder de consumo e os que têm pouco. Porém este equilíbrio depende mais de vontade política que qualquer outro fator.

Quando se fala de consumo de bens e serviços, deve-se observar que os recursos não são infinitos e, em muitos casos, estes produtos usam matérias primas extraídas da natureza e esta tem um tempo para conseguir produzi-la. Uma medida, de caráter global, que de alguma forma está relacionado ao que se designou genericamente de consumismo, é a chamada Pegada Ecológica ("FootPrint" do inglês - FIG. 24) [12, 36, 39, 40] (Anexo B). Esta medida é a área total necessária para produzir alimentos, energia e insumos e também eliminar a 
poluição (absorção de carbono, por exemplo) de cada ser humano de maneira sustentável.

Segundo a organização não-governamental WWF (World Wildlife Fund) e o programa da ONU, PNUMA (Programa das Nações Unidas para o Meio Ambiente) [41], 1,8 hectares de terra produtiva por habitante da Terra é o limite máximo para cumprir esse objetivo, mas atualmente a área utilizada per capita é 2,1 hectares [12], ou seja, há um déficit de mais de $16 \%$. Esse conceito foi estabelecido em função das atividades humanas "traduzidas" em áreas físicas tais como: área construída; área de produção de energia; área de pesca; área de produtos florestais; área de pastos e área de agricultura.

Percebe-se claramente a partir desses dados, que a inclusão da grande maioria da população dentro da classe considerada consumidora, tornará ainda mais dramático o que já é um grande problema.

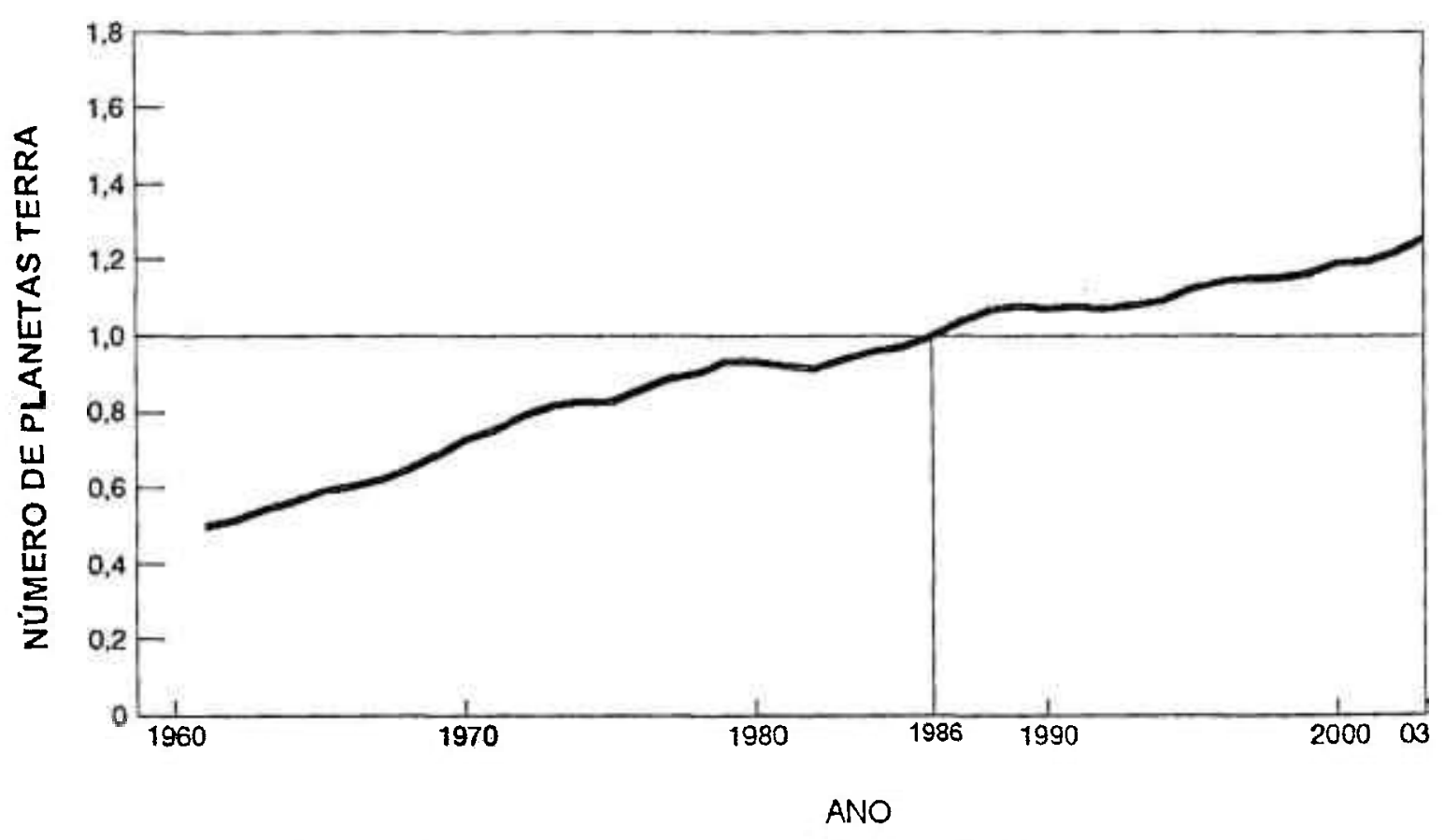

FIGURA 9 - Evolução da Pressão Ecológica Global - Fonte [12].

Pode-se observar na FIG.9 gráfico que o ano de 1986 marca o ano onde o mundo alcançou o limite da sustentabilidade de modo global. A partir daí, o consumo continuou em ascensão, e com ele as emissões de gases efeito estufa, a desertificação, o desflorestamento a perda de diversidade biológica, apenas para citar alguns dos problemas ambientais atuais. 
$\mathrm{Na}$ questão de consumo e meio ambiente, destaca-se o setor de energia, pois, de acordo com o índice da "Pegada Ecológica" [12], este é o item que mais causa impacto no meio ambiente, principalmente por ser o setor que mais demanda combustíveis fósseis. A FIG.9 mostra que a parte fóssil da matriz energética mundial representa mais que $80 \%$ de toda energia primária consumida mundialmente.

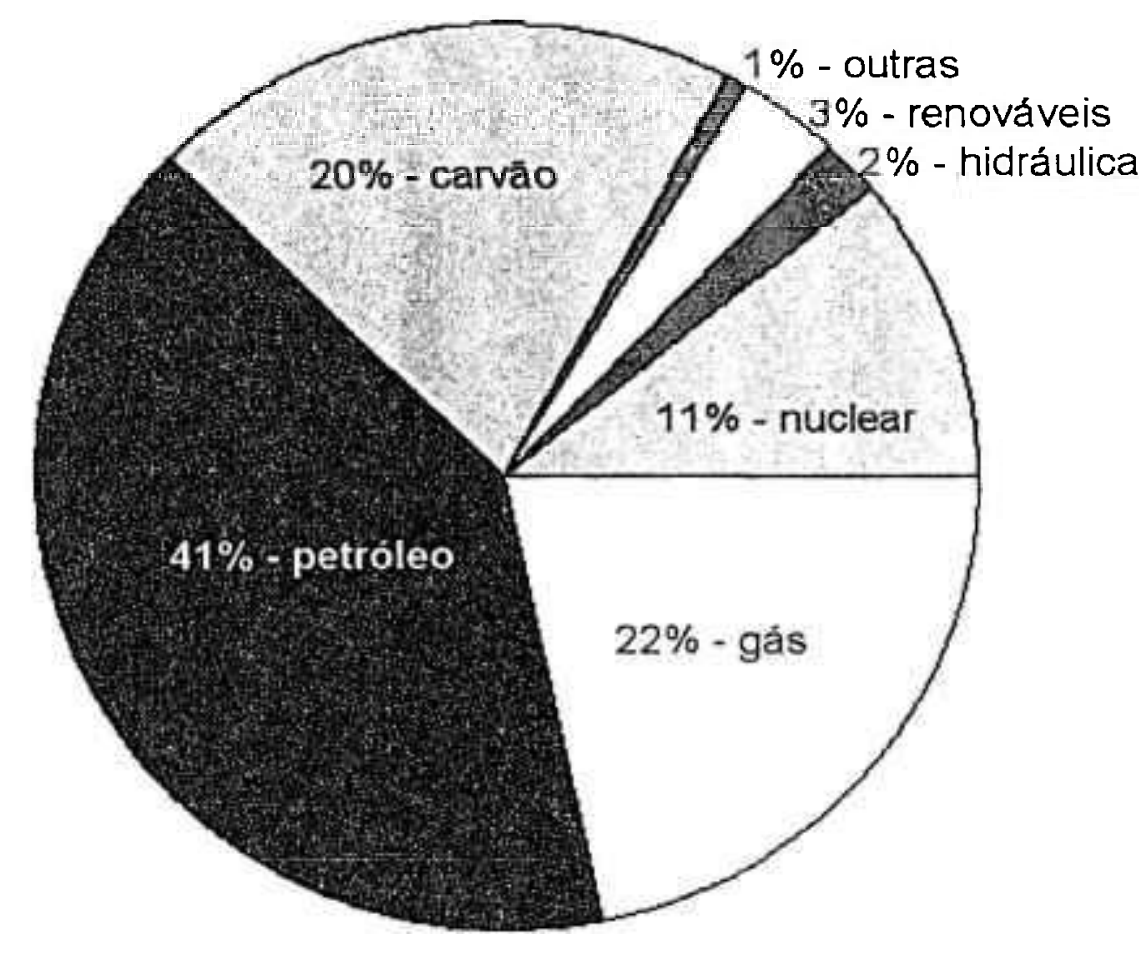

FIGURA 10 - Participação de cada tipo de combustível na matriz energética mundial (Energia Primaria - 2005) AIE [30].

Na FIG.10, observa-se que é muito pequena a participação de fontes de energia renováveis. O avanço de economias como a da China e da Índia, necessitará de grande quantidade de energia e caso o crescimento no fornecimento de energia se mantenha na mesma estrutura atual, os problemas ambientais tenderão a aumentar significativamente.

A inclusão de pessoas de países em desenvolvimento dentro do grupo dos considerados consumidores é, entre outros, o que apregoa (sinceramente ou não, mas esta já é outra questão a ser analisada), a chamada globalização das 
economias, cujos preceitos são alardeados justamente pelas grandes economias. A maioria esmagadora das solicitações de consumo diz respeito ao estilo de vida e também da estética e da cultura que são ditados por estas sociedades dominantes. São exatamente estas sociedades também as maiores responsáveis pelo desequilíbrio medido pelo índice de Pegada Ecológica [36].

Talvez esteja neste ponto a raiz dos problemas de segurança que se observam hoje nas metrópoles de países em desenvolvimento. 


\section{CONSUMO, MEIO AMBIENTE E SOCIEDADE}

Questões ambientais são normalmente tratadas em três niveis: local (como por exemplo, o ar poluído da cidade de São Paulo), regional (como por exemplo, a chamada chuva ácida) [42] e global (como por exemplo, o aquecimento global do planeta [43]). As causas desses problemas dizem respeito às atividades humanas intensivas, principalmente as que envolvem o ciclo da energia, como nos exemplos citados acima [44]. O ciclo da energia é responsável por mais da metade dos gases de Efeito Estufa lançados na atmosfera terrestre (FIG.11).

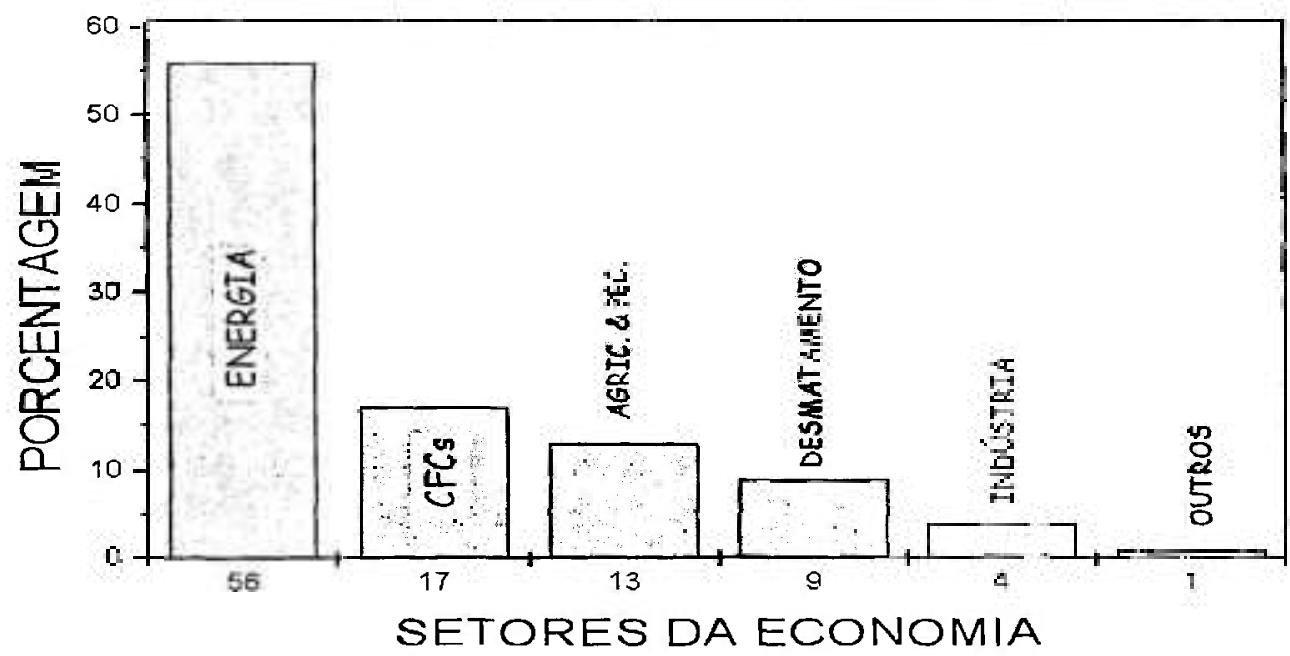

FIGURA 11 - Contribuição dos Vários Setores para o Efeito Estufa [45].

A partir da constatação óbvia de que só é possível consumir, sejam produtos ou serviços, através do uso de alguma forma de energia, fica igualmente óbvia a inter-relação entre Consumo e Meio Ambiente. Ou, com mais razão ainda, Consumismo e Meio Ambiente.

Olhando para o gráfico da Pegada Ecológica (FIG. 9), percebe-se que a população e o seu padrão de consumo estão "sugando" do planeta o seu potencial de auto-regeneração, de maneira contínua e crescente. Contudo, esse "néctar" terrestre como já visto, não é para todos. 
A FIG.12 a seguir mostra como o planeta esta perdendo a capacidade de sustentar todas as espécies através do índice Planeta Vivo [12]. O WWF criou esse índice que é uma relação entre a quantidade de espécies que existem no planeta e as que foram eliminadas (Anexo B).

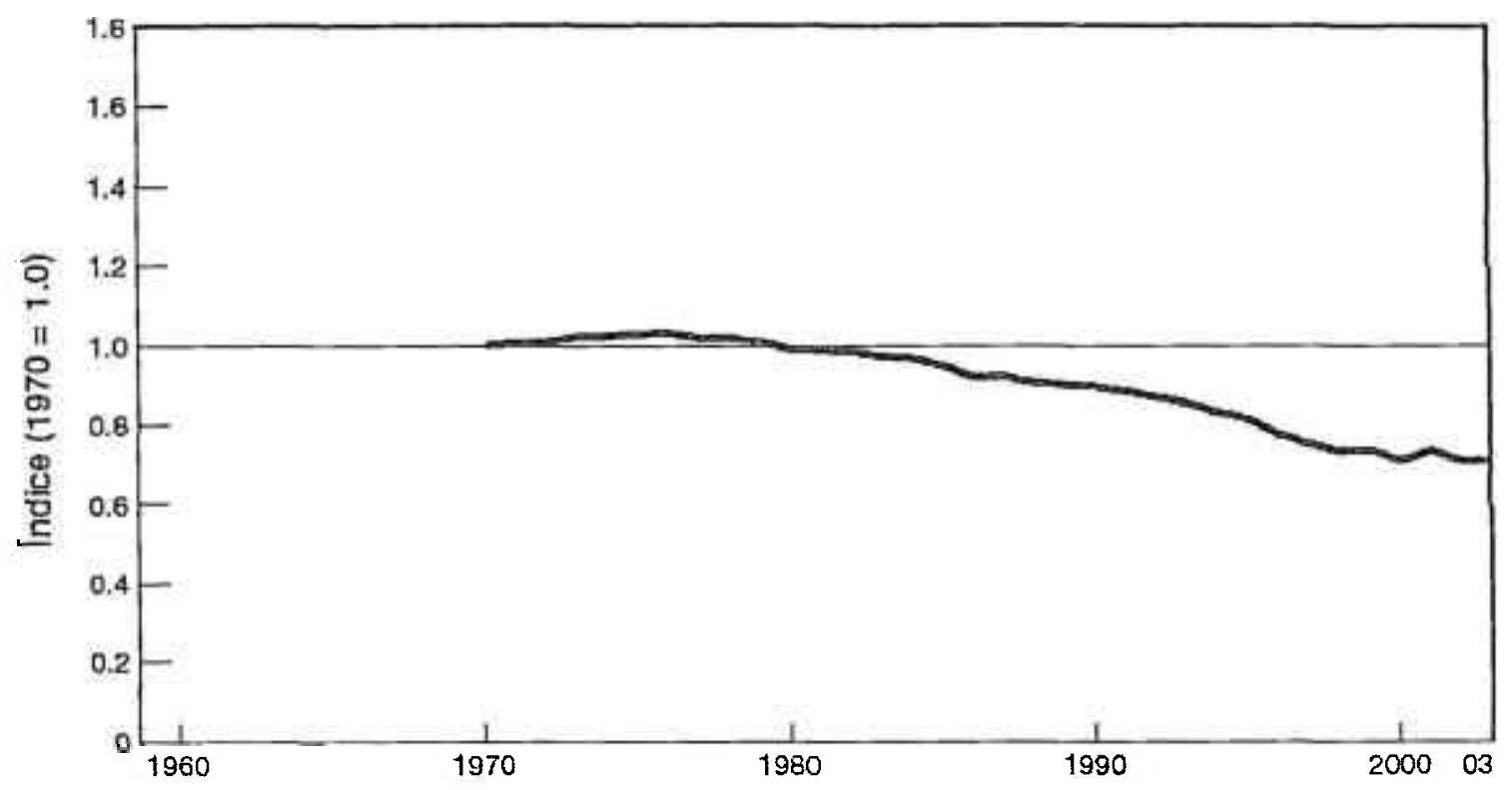

FIGURA 12 - Índice Planeta Vivo 1970 - 2005 [12].

Observa-se que de 1975 até a 2003 o número de espécies caiu de forma acentuada e continua e mais fortemente após metade da década de 1980 , período que o planeta atingiu seu limite de sustentabilidade. Fazendo uma comparação com a FIG.9, pode-se notar que à medida que o planeta torna-se insustentável, ou seja, se consome mais que se deve, as espécies vão se extinguindo.

De modo a colocar as coisas de maneira mais objetiva, introduz-se aqui outra figura de mérito: Índice de Sustentabilidade Ambiental (ESI do inglês) [46]. Trata-se de uma medida global das potencialidades ambientais futuras de um pais baseada numa série de 68 fatores agrupados em 5 classes:

1. Sistemas Ambientais (melhorando ou piorando);

2. Redução de "Stress" (grau de influência das várias atividades);

3. Vulnerabilidade Humana (saúde, educação, etc.);

4. Capacidade Sócio-Institucional do país (política interna);

5. Grau de Cooperação Internacional (política externa). 
Esse índice é fornecido anualmente pela associação de ONG (Global Leaders of Tommorrow Environment Task Force), o Fórum Econômico Mundial e as universidades de Yale e Columbia (Anexo B).

Observa-se, analisando o ESI (Environment Sustentability Index) dos vários países, que o desenvolvimento econômico registrado por uma nação, leva ao longo do tempo a uma melhora das suas condições ambientais. Esse fenômeno se dá por várias razões, dentre as quais a própria condição social do povo, com maior conscientização (educação) que o leva a influenciar de forma mais incisiva na definição de políticas públicas favoráveis às questões ambientais (democracia).

Outro índice de interesse é o conhecido Índice de Desenvolvimento Humano [47] (IDH - Anexo B) que é elaborado anualmente pelo Programa das Nações Unidas para o Desenvolvimento (PNUD) para avaliar a qualidade de vida das pessoas nos paises em que vivem.

Hoje os países com melhor qualidade ambiental são justamente aqueles com melhores indicadores de qualidade de vida. A FIG.13, a seguir, esboça uma tendência que permite essa conclusão.

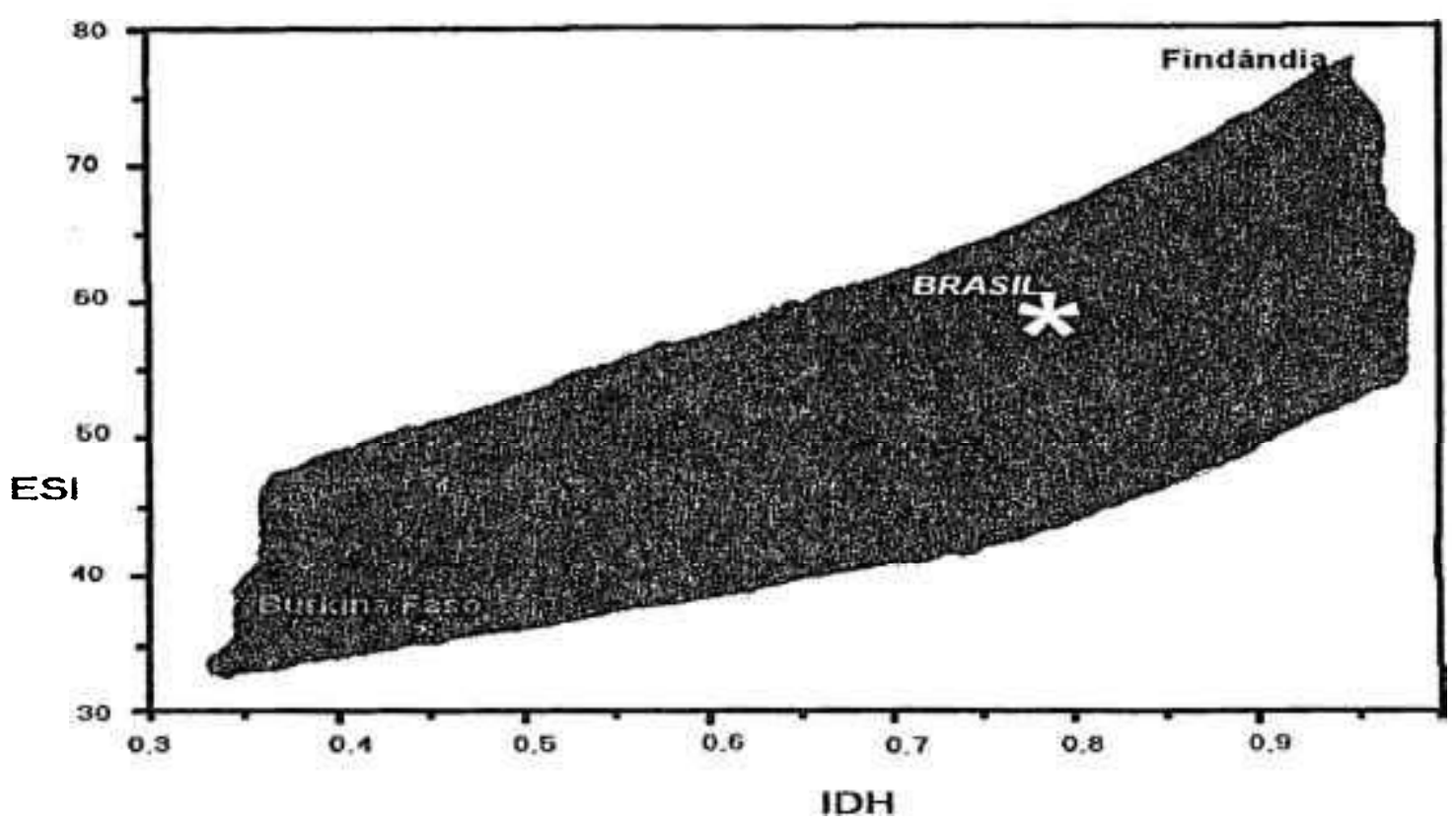

FIGURA 13 - Índice de Sustentabilidade Ambiental x IDH [48].

O desenvolvimento econômico e social (representado pelo IDH) dos países desenvolvidos promoveu, em geral para esses países, uma melhor condição 
ambiental no presente e melhores perspectivas para o futuro (ESI), comparativamente à maioria dos países subdesenvolvidos. Analisando a evolução recente da economia global, percebe-se que a condição é tal que países periféricos propiciaram, e continuam a prover as melhores condições do meio ambiente dos países centrais, em detrimento próprio. Tudo isso leva a um desequilibrio desses termos entre os dois blocos que pode se tornar até dramático e talvez irreversível, condenando, em alguns casos mais graves, as populações dessas nações a viverem abaixo de padrões aceitáveis por absoluta falta de condições do seu próprio meio ambiental. Isso é devido a vários motivos, tais como a transferência de fábricas obsoletas inteiras ou o estágio "sujo" do processo de produção para os países pobres, exploração dos insumos naturais necessários de todas as ordens, leis ambientais mais rígidas dos países ricos, incentivos fiscais favoráveis e menores custos de produção dos países pobres, etc.

O processo que levou a esta atual situação ambiental dos países subdesenvolvidos, como é óbvio pela própria classificação desses paises, não induziu uma elevação das condições socioeconômicas dessas regiões. Isso por inúmeras razões, dentre as quais aquela que é, além de uma das causas, também e ao mesmo tempo o efeito: a corrupção. Esse fator foi alimentado, dentre outras fontes, principalmente por interesses econômicos das economias mais fortes, talvez pelos mesmos motivos citados acima que fizeram o ESI dos países ricos se manterem em condições mais favoráveis que nos países pobres. Não são necessárias citações de exemplos que comprovam esta afirmação em todo o planeta. A corrupção não só ajudou a promover, ao longo do tempo, a dilapidação sócio-econômico-ambiental das nações mais pobres, como também foi um fator importante na segregação interna e intensa no seio da sua própria sociedade.

Toda discussão sobre emissões de $\mathrm{CO}_{2}$, relação entre sociedade e meio ambiente, etc., deve levar em conta outra variável de grande relevância na atualidade: os resíduos resultantes do consumo, ou simplesmente o lixo.

No dicionário [49], lixo é definido como: "1. Aquilo que se varre de casa, do jardim da rua e se joga fora, entulho. 2. Tudo o que não presta e se joga fora. 3. Sujidade, sujeira, imundice. 4. Coisas ou coisas inúteis, velhas sem valor". 
Com a migração contínua do campo para a cidade, onde a produção de rejeitos é muito maior [38], observa-se a dificuldade de resolver este problema, que ficará cada vez maior caso não sejam tomadas medidas urgentes.

A população mundial gera em média 730 milhões de toneladas de lixo por ano [50]. Grande parte destes residuos poderia retornar a cadeia de produção, reduzindo sensivelmente a necessidade de matérias primas e energia.

A renda per capita de uma população tem influência na quantidade de lixo produzida por habitante, porém a relação não é direta, pois países com renda per capita muito semelhante têm diferenças significativas na questão de produção de resíduos (TAB.4).

TABELA 4 - Produção anual de lixo de alguns países selecionados

\begin{tabular}{l|c|c|c|c}
\hline Países & $\begin{array}{c}\text { Lixo/dia } \\
\text { kg/hab.ano }\end{array}$ & $\begin{array}{c}\text { Renda per } \\
\text { capita (US\$) }\end{array}$ & IDH & $\begin{array}{c}\text { Gramas de lixo } \\
\text { por US\$ per capita }\end{array}$ \\
\hline AUSTRALIA & 580 & $28.260,00$ & 0,946 & 20,524 \\
\hline SUECIA & 303 & $26.050,00$ & 0,946 & 11,631 \\
\hline CANADÁ & 361 & $29.480,00$ & 0,943 & 12,246 \\
\hline HOLANDA & 456 & $29.100,00$ & 0,942 & 15,670 \\
\hline EUA & 840 & $35.750,00$ & 0,939 & 23,497 \\
\hline JAPĀO & 387 & $26.940,00$ & 0,938 & 14,365 \\
\hline ALEMANHA & 431 & $27.100,00$ & 0,925 & 15,904 \\
\hline MEXXICO & 237 & $8.970,00$ & 0,802 & 26,421 \\
\hline BRASIL & 270 & $7.700,00$ & 0,775 & 35,065 \\
\hline CHINA & 58 & $4.580,00$ & 0,745 & 12,664 \\
\hline INDONÉSIA & 62 & $3.230,00$ & 0,692 & 19,195 \\
\hline ÍNDIA & 146 & $2.670,00$ & 0,595 & 54,682 \\
\hline
\end{tabular}

Fonte: Adaptado: Santos L..C. [50]

Os dados da TAB.4 foram ordenados em função do IDH. Não existe, pela amostragem da tabela, uma relação direta entre renda per capita e geração de lixo (última coluna da tabela). Fica claro, no entanto, que países de menor IDH geram proporcionalmente à renda, mais resíduos que os de maior IDH. 
Relacionando, por exemplo, os EUA e o Brasil, enquanto a renda per capita brasileira é cerca de $1 / 4$ da renda americana, a produção de resíduos é cerca de $70 \%$ maior. Esta é uma comparação um tanto quanto simplória, pois não se levou em consideração, por exemplo, a composição do lixo de cada país na proporção em que ele é reciclado. Porém, como a produção de resíduos está de uma forma ou outra relacionada com o estilo de vida, influi na composição do ESI, este fato ilustra mais uma vez a tendência observada na FIG.13.

O volume de lixo é de grande importância assim como o seu destino. $O$ reaproveitamento dos resíduos é uma necessidade urgente, pois diminuiria o impacto ambiental do homem no planeta.

A FIG.14 é apenas uma amostra impressionante de um depósito de pneus usados nos EUA na década de 70. Retrata a pouca importância dada às condições ambientais justamente na época em que se começou a considerar mais seriamente o meio ambiente como algo fundamental à vida humana.

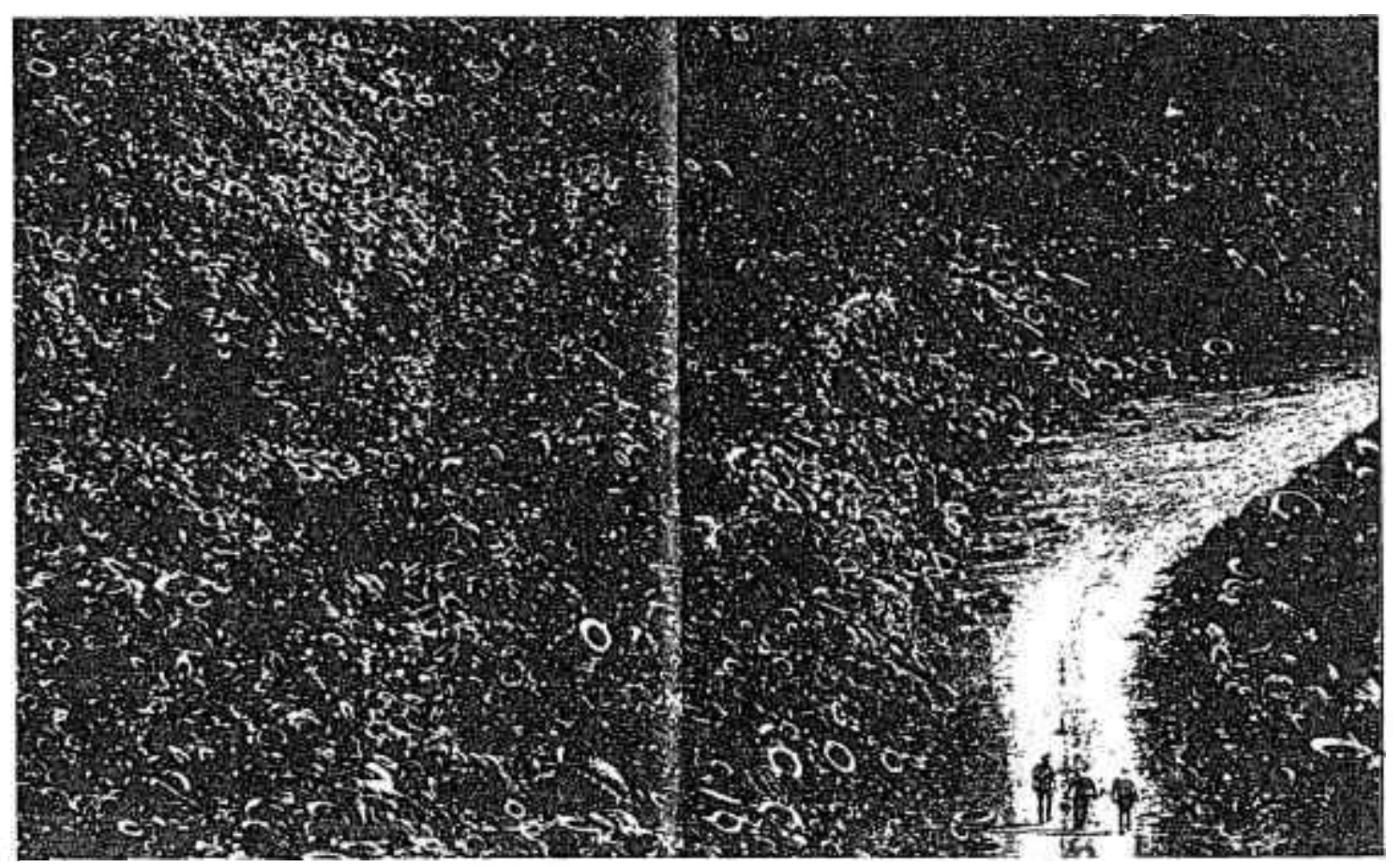

FIGURA 14 - Depósito de pneus usados a céu aberto nos EUA [51].

O desenvolvimento econômico (representado pelo PIB/capita) e social (representado pelo IDH) [52] dos países desenvolvidos promoveu, em geral para esses paises, uma melhor condição ambiental no presente e melhores 
perspectivas para o futuro (ESI), comparativamente à maioria dos países subdesenvolvidos, como observado na FIG.13. No entanto, para melhorar o IDH de uma economia é necessário fazer a economia crescer. Pela tendência observada na FIG.15, uma renda anual per capita de US\$5000 que é o mínimo para se alcançar um IDH alto (maior que 0,8 - Anexo B).

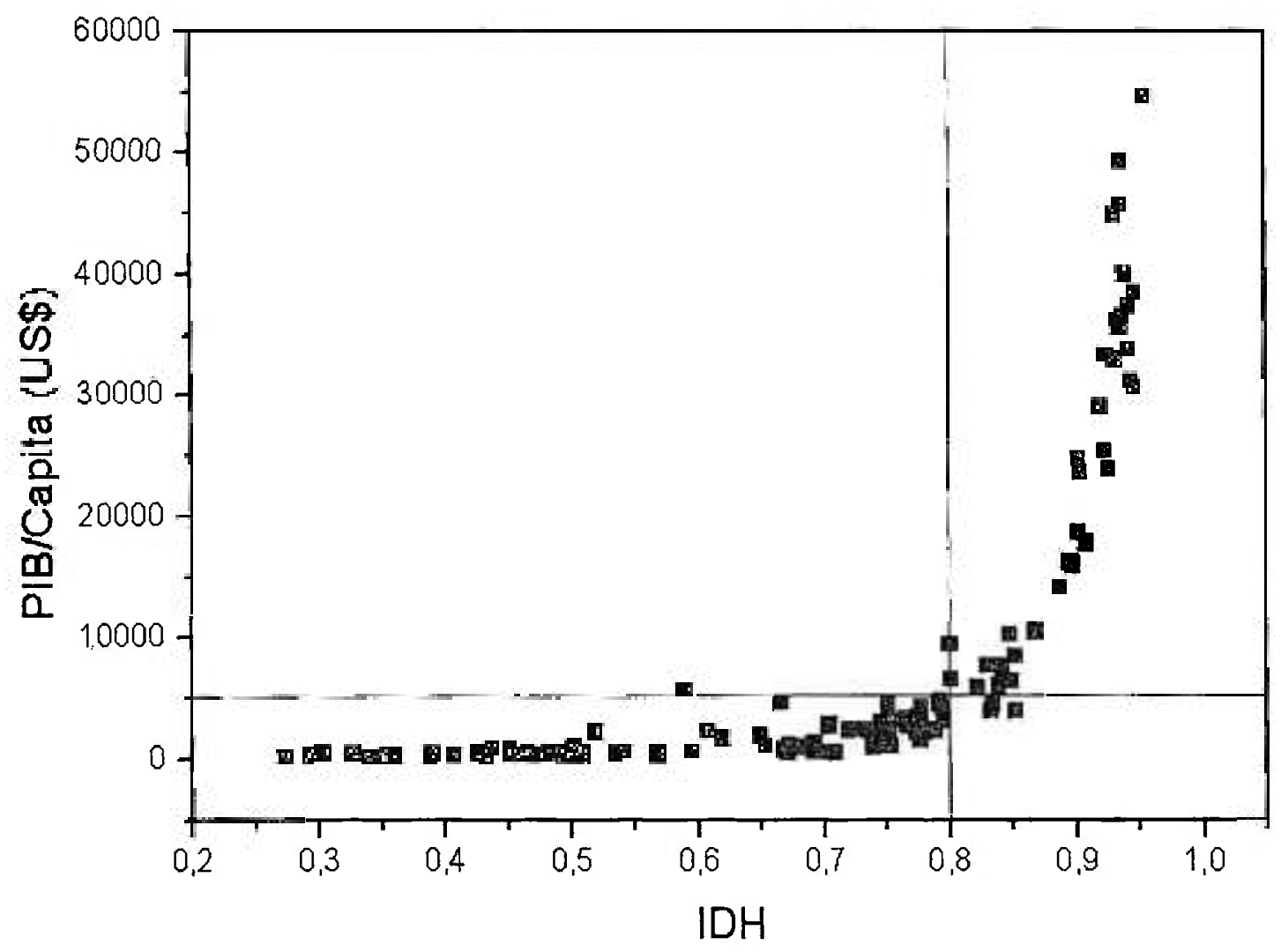

FIGURA 15 - PIB/Capita versus IDH das nações para algumas economias.

Foi visto através do índice Pegada Ecológica (FootPrint) [12, 39], que os insumos fornecidos pelo meio ambiente estão sendo consumidos pela humanidade de modo não sustentável e de maneira contínua e crescente. Basicamente esta situação é devida principalmente aos paises do bloco desenvolvido, cujas populações detêm melhores condições de vida (maiores IDH), mas não só por estes. Essa afirmação pode ser constatada na FIG.16 a seguir. 


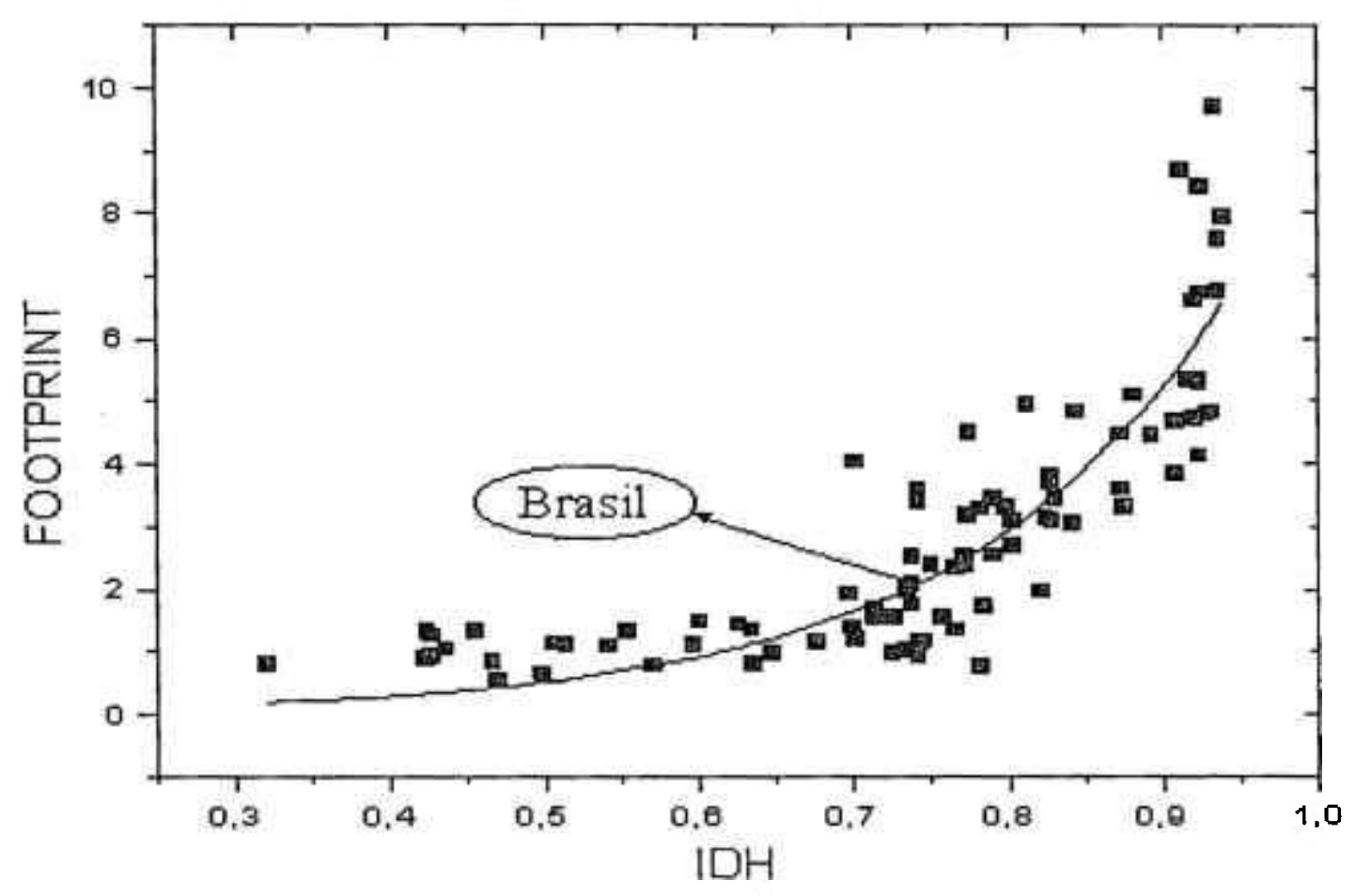

FIGURA 16 - Pegada ecológica em diferentes níveis de IDH.

Sendo o IDH uma medida do padrão de vida das pessoas e a PE a área necessária para a natureza produzir os insumos e absorver seus rejeitos, chega-se aqui a um impasse: é necessário melhorar as condições de vida das populações mais pobres, mas para que isso aconteça, essas pessoas consumirão mais produtos, mantendo-se o mesmo sistema econômico e social vigente, aumentará PE das populações mais pobres, o que agravará o grande déficit de sustentabilidade mostrado na FIG.9.

Dados da OMS (Organização Mundial da Saúde) mostram as desigualdades mundiais. Enquanto os mais pobres (cerca de 300 milhões de pessoas) mal conseguem o mínimo de alimentos (em alguns casos há realmente fome), os mais ricos têm um consumo de proteínas que pode chegar a 7 vezes mais que o recomendado pela própria OMS [53]. Essa realidade preocupa a todos, inclusive os governos dos países desenvolvidos.

Para que se consiga um equilibrio melhor dever-se-ia investir em produtos mais eficientes do ponto de vista ambiental, onde se consiga satisfazer as aspirações da demanda sem comprometer o meio ambiente. 
Todos os dados mostram um cenário no mínimo preocupante. Isso pode ser confirmado por um relatório secreto obtido pela revista Observer, e reproduzido no Brasil pela revista Carta Capital [54], encomendado, segundo a revista, por um influente conselheiro do Pentágono. O relatório trata destas questões com um viés que transcende ao debate científico, colocando o problema das mudanças climáticas e sustentabilidade, ao nível de segurança nacional. As principais conclusões desse relatório são:

- "As guerras futuras serão travadas por sobrevivência e não por religião, ideologia ou honra nacional,

- Chuvas torrenciais destruirão barreiras costeiras e tornarão grande parte da Holanda inabitável. Cidades como Haia serão abandonadas. Na Califórnia, barreiras no Rio Sacramento serão rompidas, interrompendo o sistema de aquedutos que leva a água do Norte ao Sul,

- Mortes por guerra e fome chegarão aos milhões até a população do planeta ser reduzida a um nivel sustentável,

-Rebeliões e conflitos internos esfacelarão a Índia, a África do Sul e a Indonésia,

- O acesso à água se tornará um campo de batalha. O Nilo, o Danúbio e o Amazonas são mencionados como sendo de alto risco,

- Uma 'redução significativa' na capacidade do planeta sustentar sua população atual ficará evidente nos próximos 20 anos,

- Áreas ricas como os EUA e a Europa se transformariam em 'fortalezas virtuais' para impedir a chegada de migrantes provenientes de áreas inundadas pela elevação do nível do mar ou nas quais a agricultura tornou-se inviável. Ondas de barcos de imigrantes se tornarão um problema significativo,

- A proliferação de armas nucleares será inevitável. O Japão, a Coréia do Sul e a Alemanha desenvolverão capacidades nucleares, como também o Irã, o Egito e a Coréia do Norte. Israel, China, Índia e Paquistão se inclinarão a usar suas armas nucleares,

-Até 2010, nos EUA e na Europa, haverá um aumento de 33\% nos dias com temperaturas acima de $32{ }^{\circ} \mathrm{C}$. O clima começará a perturbar a economia à medida que as chuvas, secas e ondas de calor tragam o caos à agricultura.

- Mais de 400 milhões de pessoas em regiões subtropicais estarão em grave risco,

-A Europa enfrentará enormes conflitos internos ao lidar com as massas de migrantes que desembarcarão em sua costa. Imigrantes da Escandinávia procurarão climas mais quentes ao sul, e o sul da Europa será invadido por refugiados de países duramente atingidos na África, 
- Megassecas afetarão os celeiros do mundo, incluindo o MeioOeste norte-americano, onde fortes ventos provocarão erosão do solo,

- A enorme população chinesa e sua demanda por alimentos a farão vulnerável. Bangladesh "se tornará quase inabitável devido à elevação do nível do mar, que contaminará seus suprimentos de água doce" [54].

No entanto, tais previsões e os fatos reais que já se sucederam, ainda não conseguiram fazer com que o congresso dos EUA (maior emissor mundial de $\mathrm{CO}_{2}$ ) ratificasse o Protocolo de Quioto, comprometendo-se assim a diminuir as suas emissões.

Analisando-se tudo o que foi aqui exposto, tem-se agora aqui a seguinte situação: para se melhorar a condição social de um país (IDH) (melhorando por conseqüência sua situação ambiental (ESI)), deve-se aumentar a renda per capita (PIB/capita) o que, por sua vez, levará a aumentar a sua Pegada Ecológica. Fica claro então que este modelo econômico, que vem evoluindo desde a Revolução Industrial, está chegando a um perigoso impasse! 


\section{UM NOVO MUNDO}

A necessidade de, aos poucos, se introduzir um tipo de sociedade que seja sustentável sobre todos os aspectos, não pode ser contestada. No entanto o plano global para levar a cabo esse grande projeto, ainda está nos primeiros traços. Interesses conflitantes estão em jogo e isso conduz o problema de volta ao campo dos mais elementares desafios que o homem tem enfrentado desde os tempos das cavernas. Mas foi justamente a sua capacidade de tratar, de uma forma ou de outra, esses conflitos, através de toda sua longa trajetória na Terra, que fez dele um ser único, seja no sentido de enaltecer suas inúmeras qualidades, seja para criticar os também inúmeros defeitos.

Em recente relatório do IPCC (Intergovernmental Panel on Climate Change) (grupo III) [55] que trata da mitigação do Aquecimento Global por meio da redução das emissões dos gases de Efeito Estufa, evidenciaram-se mais uma vez um grande conflito, desta vez político, entre os países ricos e os países pobres. Concluiu-se que com investimento de apenas $3 \%$ do PIB mundial seria possível uma solução razoável para o problema do Aquecimento Global. A humanidade já dispõe de tecnologia para colocar em prática essa redução, só faltando para isso vontade política. Toda a humanidade parece depender hoje dessa vontade.

No campo do consumo também existem soluções que, na verdade, fazem parte do conjunto global de transformações que conduzirão a humanidade à sustentabilidade. É esta uma contribuição do presente trabalho e estão aqui dividas em 6 grupos: educação, pesquisa, rejeitos, energia, política e recuperação ambiental. 


\subsection{Educação}

A inclusão do item educação nas Metas de Desenvolvimento do milênio [56], já foi um passo importante.

Muitos países estão tentando melhorar os níveis de educação da população. Isso é importante no sentido de facilitar a conscientização e compreensão da urgência da conservação e melhoria das condições ambientais.

A evolução da educação básica tende a dar ao indivíduo uma maior compreensão sobre os problemas do mundo, o que o torna uma arma a favor do meio ambiente.

Inserida na educação geral, a chamada educação ambiental ganhou uma importância particular. Segundo lei federal brasileira $n^{\circ} 9.795$ de 27 de abril de 1999, que trata da educação ambiental no território nacional, torna-se obrigatória a educação ambiental nas escolas brasileiras, define em seu caput o que vem a ser "educação ambiental":

"Entendem-se por educação ambiental os processos por meio dos quais 0 indivíduo e a coletividade constroem valores sociais, conhecimentos, habilidades, atitudes e competências voltadas para a conservação do meio ambiente, bem de uso comum do povo, essencial à sadia qualidade de vida e sua sustentabilidade" [57].

Tal lei demonstra a seriedade do tema em questão. Nas palavras do deputado alemão Johannes Gerlach:

\footnotetext{
"O assunto educação ambiental nunca estará defasado, superado, pois a cada dia é preciso novos ensinamentos para garantir a sobrevivência das gerações futuras. Essa é uma luta para toda a vida" [58].
}

\subsubsection{Pesquisa}

No grupo pesquisa, a formação dos Painéis de estudos climáticos pela ONU é uma das ações mais importantes. O Climate Institute [59], recentemente, divulgou que entrará em funcionamento no ano de 2008 o centro de vigilância climática global mais alto do mundo, localizado a $4.581 \mathrm{~m}$ acima do nível do mar, 
no México. ONGs como WWF e o GreenPeace entre tantas outras, o PNUMA (também da ONU) e as universidades têm participações fundamentais no sentido de bem entender o que ocorre com o nosso planeta. Tudo isso faz parte do equacionamento para solução de uma boa parte dos problemas, pois, com informações bem fundamentadas será possível tomar as decisões corretas no sentido de diminuir os impactos das ações do homem no planeta.

No entanto existem forças que financiam pesquisas no sentido contrário às causas do aquecimento global. Um exemplo disso é a atitude da empresa de petróleo Exxon, que de acordo com notícia divulgada pelo site [60] disponibilizou 100 milhões de dólares para pesquisas que contradissessem o relatório III do IPCC divulgado no início de 2007. Seguindo essas correntes contrárias, os livros "Máfia Verde" [61] e "A Fraude do Crescimento" [62] entre outros que negam a influência do homem no aquecimento global. Essas correntes contrárias são, contudo, de grande importância, desde que estejam em busca da verdade dos fatos. Isso poderá contribuir para uma real e mais consensual dimensão do problema e com isso ter informações mais ricas e corretas para que decisões possam ser tomadas de forma coerente e assertiva, tanto na esfera mundial, regional ou mesmo individual.

\subsection{Rejeitos}

No capítulo anterior o problema do lixo foi classificado como de grande relevância para a questão ambiental global.

O conceito de reuso e reciclagem são, neste contexto, interessantes pois vêem no lixo uma fonte de matérias primas. Em muitos casos o reuso e/ou reciclagem apresentam preços bastante atraentes, como no caso do alumínio cujo processo de reciclagem economiza $75 \%$ da energia necessária para produzir a mesma quantidade de alumínio original [63].

Uma ferramenta bastante usada para se definir os pontos onde os produtos podem impactar menos o meio ambiente é a análise do ciclo de vida do produto (da produção ao descarte).

As normas ambientais (série ISO 14000) [64] determinam que as empresas estabeleçam o "ciclo de vida" de seus produtos, ou seja, verificar desde a fonte da matéria prima até como este produto será descartado no ambiente. Isto 
é o que se chama de "ciclo de vida", também denominado ciclo de "berço ao túmulo". A utilização desta norma é em si um grande avanço, porém não é um ciclo fechado.

Para Grach [65], o ciclo de vida pode ser descrito como:

"[...] uma técnica de avaliação que relaciona atividades, produtos e materiais do início ao fim de sua existência, desde o projeto e suas pesquisas, passando pela seleção, extração, transformação das matérias primas; construção e produção dos produtos relacionados; processos de marketing, transporte, vendas e distribuição, uso das mais variadas formas, incluindo o uso correto, incorreto, alternativo, reuso, desuso; desmontagem, conserto, remontagem, reaproveitamento de partes, reciclagem ou compostagem nas mais variadas formas e finalizando com o descarte final"

Essa definição de ciclo de vida de um produto é bastante próxima da necessidade que as indústrias têm para conseguir fornecer produtos que sejam sustentáveis nos 3 sentidos sugeridos pela ONU: econômico social e ambiental.

Baseado na idéia de ciclo de vida do produto foi criado o conceito intitulado: "de berço ao berço" [36], que consiste em projetar produtos que quando tiverem sua vida útil finalizada, possam retornar ao processo como matéria prima para a produção do mesmo ou de outro produto, entrando assim em um ciclo de vida permanente. Como demonstra a ilustração 17.

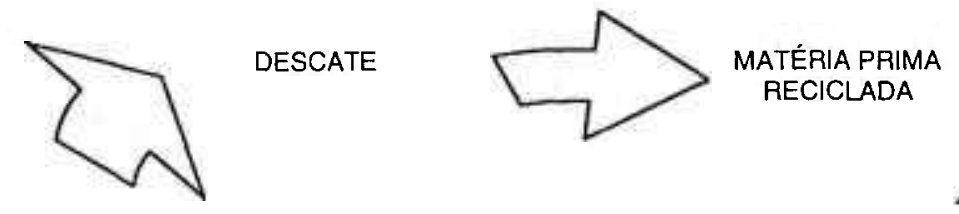

FINAL DA VIDA DO PRODUTO

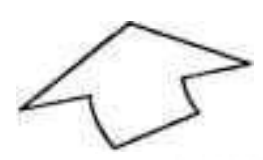

PRODUTO ACABADO
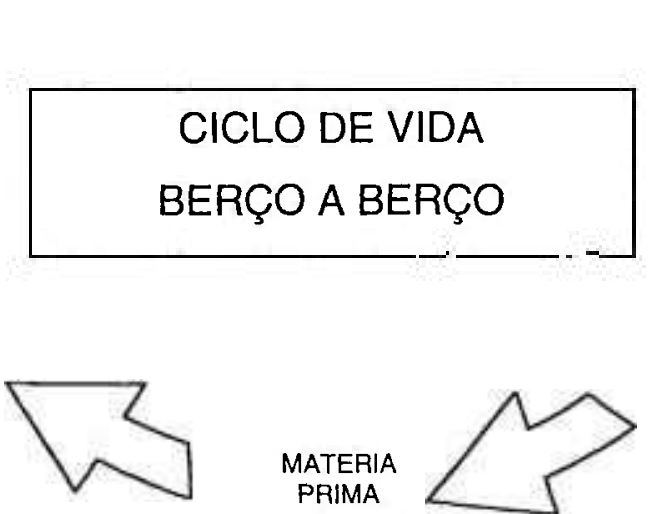

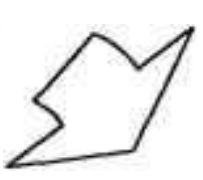

PRODUTO ACABADO

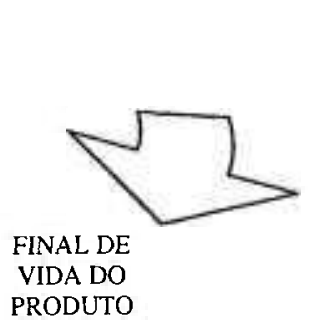

FIGURA 17 - Ciclo de vida de produtos com a política de "berço a berço". 
Aproveitando o conceito acima mostrado, é de grande contribuição a introdução da palavra "preciclar" [66], ainda como um neologismo, porém que deve ter muita força nos próximos anos.

"Preciclar" é o ato de antever a reciclagem, ou seja, pensar no destino final do produto após a sua utilização no momento da compra. Esta é a atitude de um consumidor inteligente. $\mathrm{O}$ ato de preciclar faz com que se veja o produto como um todo, inclusive com o resíduo do produto ou de sua utilização (embalagem, restos, descarte), dando preferência a produtos que sejam mais fáceis de reciclar (papel em vez de plástico, abastecer o carro com álcool e não gasolina ou diesel), entre outras muitas atitudes [66].

$\mathrm{Na}$ realidade pensar no lixo, reciclar e reusar são formas de preservar a natureza e conseqüentemente o meio ambiente além de possibilitar grande economia de recursos naturais e financeiros [66].

Para seguir esse modo de pensar do consumidor e oferecer produtos cada vez mais corretos ambientalmente, surgiu o conceito de Eco-Design, que leva em conta todos os itens do ciclo de vida do produto, diferenciando-se em sua análise pelo fato de levar em consideração um objetivo de baixo ou nenhum rejeito, e, nos casos de haver algum rejeito, este seja de fácil absorção pela natureza [67].

Nesta visão de ciclo de vida de um produto é muito importante. Um dos motivos é que o espaço utilizado para o seu depósito que se torna, muitas vezes, em grandes focos de doenças, pois atraem muitos tipos de animais e em alguns países até mesmo pessoas, que vasculham o lixo a procura de algo que possam usar ou até mesmo se alimentar, podendo inclusive transformar-se em um caso de saúde pública.

Para que todas essas ações sejam realizadas, se faz necessária a criação de uma política de incentivo às empresas que se utilizam desse tipo de ferramenta. Os incentivos poderiam ser de várias formas:

-diretas - com incentivos e investimentos diretos como subsidios para viabilizar a produção entre outros e

-Indiretas - através de menores impostos. 
De acordo com matéria da revista Veja [68], a empresa de bebidas AmBev vai começar a reciclar embalagens e cacos para produzir as próprias garrafas, que representam uma grande parte do preço do produto final (cerca de $43 \%$ do preço da cerveja). O objetivo é o de reduzir o custo para a empresa, mas juntamente com isso, será de grande ajuda para combater excesso de lixo das cidades.

O conceito de ciclo de vida de berço ao berço ao ser incorporado nas práticas empresariais traria uma grande vantagem competitiva, pois teria em si um maior valor positivo de externalidades (Anexo C).

\subsection{Energia}

A produção de energia é a atividade antrópica que mais causa impacto ao meio ambiente de acordo com o índice Pegada Ecológica [12]. É evidente que avanços na substituição das atuais formas de produção de energia para opções mais limpas, é a primeira coisa que se pensaria em fazer. Porém o problema é bem mais complexo, visto algumas atitudes de empresas (principalmente petrolíferas) que relutam em romper a ordem estabelecida no mercado de energia [69]. A pesar dessa resistência, muitas ações estão sendo implementadas para a produção de energia de forma mais limpa, como no caso da Alemanha, Islândia e Brasil.

\subsubsection{Tecnologias de produção de energia}

Grande parte dos combustíveis são consumidos para a produção de energia elétrica. As usinas térmicas são as mais utilizadas, sendo o carvão o principal combustível, seguido do petróleo e gás natural (FIG.18). O atual modelo de geração de energia elétrica, sendo baseado em combustiveis de origem fóssil é, portanto, altamente poluidor. 


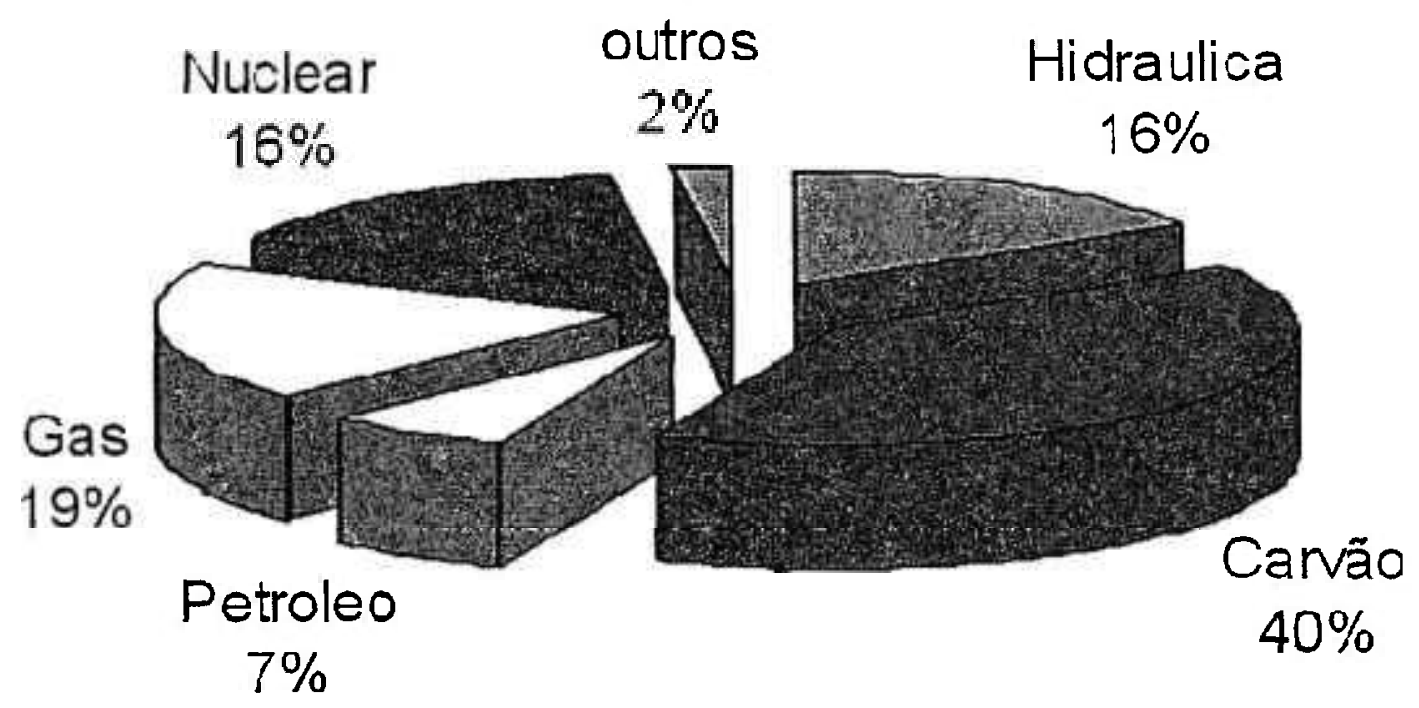

FIGURA 18 - Formas de geração energia elétrica mundial.

A pesar de algumas participações estarem percentualmente menores se comparadas a 1973 , todos os componentes tiveram um aumento significativo no seu consumo absoluto, pois se gera muito mais energia hoje do que há 30 anos. Na área de energias renováveis, apesar de pequena participação, ela tem aumentado, principalmente pelo empenho de alguns paises.

Algumas tecnologias estão sendo desenvolvidas a fim de possibilitar a produção de energia sem grandes impactos ambientais. Nesse item destaca-se a produção de energia elétrica via nuclear. Esta tem baixíssimo índice de emissões de gases na atmosfera e seu ciclo e rejeitos, sendo totalmente conhecidos, são tratados com alta tecnologia, o que diminui sensivelmente os riscos inerentes, a despeito de todas as críticas. Hoje a energia nuclear já gera quase $16 \%$ (FIG.18) da energia elétrica do mundo. Outro item que contribui a seu favor é o pouco espaço necessário para a sua implantação, que levando em conta o índice pegada ecológica, isso é uma grande vantagem.

Dentre os problemas que a área nuclear enfrenta atualmente, o político se destaca, pois a comunidade internacional teme o uso dessa tecnologia para a produção de armamentos. Outro fator negativo é o custo de construção que é elevado. Pesando os itens contra e a favor, conclui-se que esta é uma forma de energia que não pode ser ignorada e é de grande interesse que se 
avance as pesquisas nessa área, para que com isso o aumento na sua participação da matriz energética mundial seja feita com mais responsabilidade.

Os combustíveis fósseis (carvão, gás e petróleo) são usados largamente na produção de energia. Ao todo representam mais de $80 \%$ da matriz energética mundial. $E$ indiscutível que a produção de energia por essas tecnologias é algo simples e que principalmente o carvão é de grande abundância na natureza, o que torna esse tipo de geração de energia bastante competitiva. Os custos de instalação são baixos e não incluindo nestes custos as externalidades, esses combustiveis têm uma grande vantagem competitiva na atualidade, porém representam um grande problema em um futuro não muito distante.

Os combustiveis fósseis ainda estão em crescimento, segundo as previsões dos organismos internacionais (IEA, WWF, IPCC.). Esse aumento continuará, provavelmente, até 2050 e, com ele, continua o aumento de emissões de $\mathrm{CO}_{2}$. Os investimentos nessa área deverão se voltar em como minimizar as emissões de $\mathrm{CO}_{2}$, e ainda produzir energia, ou seja, o aumento da eficiência da geração.

A energia elétrica gerada pela forma hidráulica, tem um custo de instalação bastante elevado. Na maioria dos casos, porém, seu custo de operação é baixo. Essa forma de produção de energia aparentemente não causa impactos ambientais, esse impacto na instalação de uma hidroelétrica é, em alguns casos, muito grande, pois para a formação da barragem, alagam-se centenas ou até mesmo milhares de hectares, inutilizando grandes áreas. Algumas construções não previram em seu projeto o desmatamento das áreas alagadas, isso após algum tempo gera gás metano $\left(\mathrm{CH}_{4}\right.$ muito mais nocivo que o próprio $\mathrm{CO}_{2}$ ).

Um dos maiores problemas das plantas hidroelétricas é que, muitas vezes, se encontram longe do mercado consumidor. Isso, como se sabe, causa grandes perdas de energia no caminho, o que muitas vezes faz que um projeto desses tenha sua eficiência discutida. 
Uma das áreas que consomem grande parte da energia mundial é a área de transportes, assim sua participação é significativa nas emissões de gases do Efeito Estufa. Porém algumas pesquisas estão tentando de alguma forma minimizar esses impactos. Entre elas os veículos elétricos, a combustível derivados da biomassa e mesmo os veículos híbridos.

Uma tecnologia e que vem causando muita expectativa no campo da energia é a Célula a Combustível. Seu conceito é bastante antigo (cerca de 150 anos) [70], mas nos últimos anos se intensificou bastante as pesquisas que foi muito usada nas naves espaciais após 1959. As crescentes pressões mundiais pela diminuição de emissões, alavancaram vários projetos sobre células a hidrogênio no mundo. Algumas montadoras de automóveis têm departamentos inteiros voltados à pesquisa de veículos movidos a células a combustíveis $\left(\mathrm{H}_{2}\right)$.

O principal fator positivo da célula a combustível é que o resíduo resultante do processo é água e não $\mathrm{CO}_{2}$ como nos processos de combustíveis fósseis. Porém seu combustivel, o hidrogênio molecular, não existe em estado natural. Este deve ser obtido através de um processo que consome bastante energia elétrica ou através de biomassa ou ainda de alguma alternativa energética renovável. A forma como será obtido o hidrogênio será decisiva para que este venha a se estabelecer como fontes energéticas. Hoje são poucos os países que tem condições de proporcionar tal feito.

Ainda na área de transportes existem soluções surpreendentemente inteligentes, que apesar de usar tecnologias já conhecidas, possibilitaram o surgimento de automóveis com alta eficiência energética e baixas emissões. No verão de 2000, o carro híbrido de Toyota, o Prius, foi introduzido ao público norteamericano pela primeira vez, utilizando uma tecnologia que permite que ele rode com dois motores: um elétrico e outro a gasolina. Isso permite que este modelo rode mais quilômetros por litro de gasolina que outros carros similares a gasolina [71], como se observa na TAB.5. 
TABELA 5 - Comparação entre os modelos Prius e Corolla.

\begin{tabular}{l|c|c|c}
\hline \multicolumn{1}{c|}{ Característica } & Prius Híbrido & Corolla Gasolina & Diferença \\
\hline Consumo l/100 km & 4,3 & 6,9 & $38 \%$ \\
\hline Emissões de $\mathrm{CO}_{2} \mathrm{~g} / \mathrm{km}$ & 104 & 162 & $36 \%$ \\
\hline Aceleração de 0 a 100 s & 10,9 & 10,4 & $-5 \%$ \\
\hline
\end{tabular}

Fonte [72]

Os dois modelos comparados na tabela são modelos da montadora Toyota Inc. Apesar da montadora ser japonesa, os dados utilizados são de manuais de carros vendidos em Portugal. Procurou-se comparar o modelo mais próximo do automóvel híbrido Prius. Neste caso o carro selecionado foi o Corolla com motor de 1,6 , pois seu desempenho se aproxima bastante do Prius.

No exemplo do Pirus, preço o automóvel híbrido é mais caro que o automóvel similar (17\%), porém essa diferença se dissipa ao longo do tempo. Além disso, as baixas emissões podem no futuro favorecer menores tributos [73].

Esse é um caso que reúne tecnologias já existentes para criar algo novo e com conceito ambiental melhor e mais eficaz. Esses casos servem para demonstrar que existem ações possíveis para diminuir as emissões de gases efeito estufa, com tecnologias já plenamente dominadas.

Para ilustrar exemplos de países que estão na vanguarda da melhoria da matriz energética, serão relatados a seguir alguns casos de sucesso na tentativa de se melhorar a eficiência energética.

\subsubsection{Caso da Islândia}

$\mathrm{Na}$ linha do pioneirismo em questão de substituição de fontes de energia, talvez a proposta mais ambiciosa nesse sentido seja a da Islândia. País que em 1998 anunciou que em um prazo de 30 anos estaria livre da dependência de combustíveis fósseis. Sem dúvida é a primeira tentativa de se alterar a matriz energética de um país inteiro, tendo como meta a substituição total dos combustíveis fósseis [74].

A Islândia, país no extremo norte do globo, tem uma população pequena, e uma matriz energética bastante particular. Usa fontes geotérmicas e 
hidroeletricidade. A dependência de combustíveis fósseis para a produção de energia elétrica é bem pequena, neste cenário se poderia viabilizar o que alguns autores chamam de "Economia do Hidrogênio" [75]. É o caso onde a matriz energética se baseia primordialmente no hidrogênio. Grandes empresas estão investindo muitos milhões neste projeto, pois com esta atitude a Islândia tornou-se um grande laboratório [74].

Se esta decisão foi a mais acertada, somente o tempo dirá, mas em todo o caso se trata de uma experiência, no mínimo, interessante.

\subsubsection{Caso da Alemanha}

Existem várias formas de produção de energia, muitas delas podem ser implementadas em pequenas escalas. É o caso da energia solar. Apesar de não ser uma energia de baixo custo de instalação, tem um custo de produção praticamente igual a zero.

A Alemanha é um bom exemplo de política pública de incentivo à descentralização da produção de energia. O cidadão alemão pode instalar geração de energia solar em sua residência, o governo se compromete e comprar a energia excedente por um preço fixo durante 20 anos, o que torna 0 investimento bastante atraente para a população em geral [76]

Outro exemplo alemão diz respeito ao biodiesel. Na Alemanha aproximadamente $40 \%$ dos veículos são movidos a diesel e mais de 1800 postos de combustiveis oferecem biodieseis a preços competitivos devido a incentivos e, principalmente, à redução tributária. A figura abaixo mostra as vantagens, em termos ambientais, a adição de biodiesel ao diesel comum. 


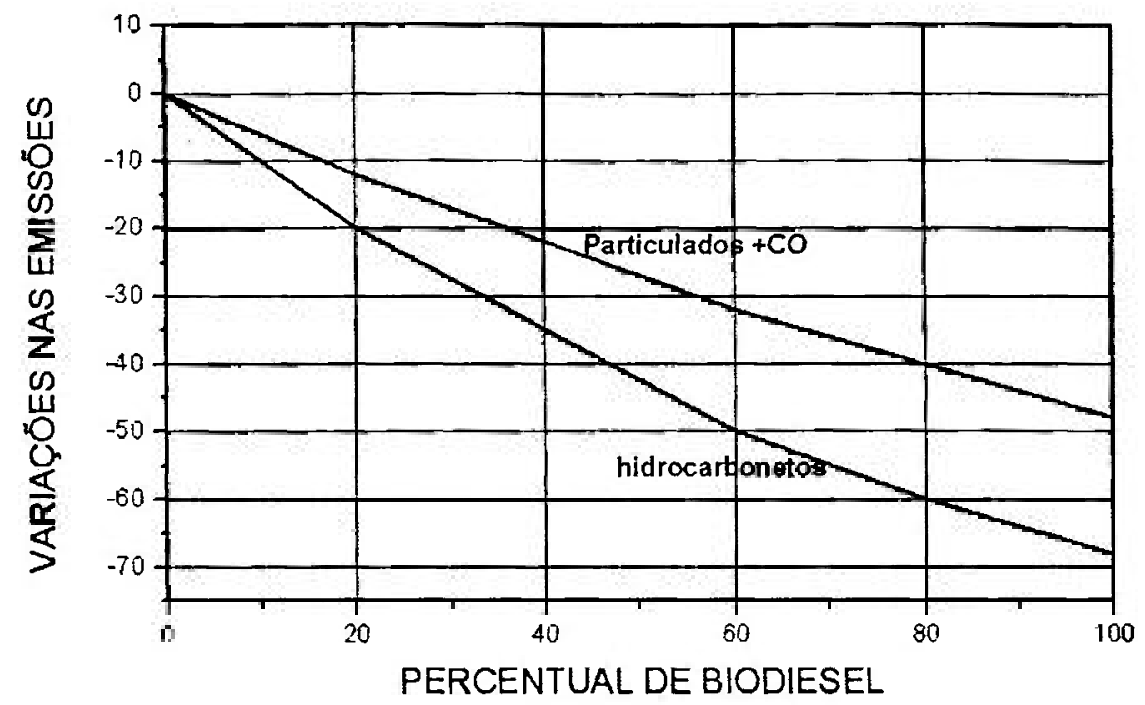

FIGURA 19 - Variações de emissões pela adição de biodiesel ao diesel comum Fonte [77].

\subsubsection{Caso do Brasil}

O Brasil foi pioneiro na criação de uma alternativa para o petróleo: a instituição do pró-álcool na década de 70 . Foi uma resposta bem sucedida à crise do petróleo que se instalava naquele momento e atingiu seu auge durante a década de 80 . Teve uma forte queda durante a década de 90 , porém fortaleceuse a partir do ano 2000 com o advento do automóvel bicombustivel, que pode utilizar tanto o álcool com a gasolina em qualquer proporção [78].

$\mathrm{Na}$ atualidade o programa brasileiro do álcool esta sendo observado como saída real para a crise ambiental que se instalou pelo mundo, sendo uma energia renovável e de fácil produção que poderia vir a ser uma forma de redução real das emissões causadas pelos combustíveis fósseis. Um automóvel a álcool emite apenas $45 \%$ das emissões de um carro de igual potência e características a gasolina, essa diferença cresce bastante, como visto acima, quando se trata de carros a diesel. Como toda energia tem seu inconveniente, o álcool compete diretamente com a produção de alimentos, o que faz com que ele tenha grandes críticos [79].

Ainda sobre o álcool, a sua produção avançou bastante nos últimos 30 anos, sendo criadas novas variedades de cana de açúcar que se adaptam a diversos tipos de solos. A transformação do vinhoto (principal resíduo do processo) como fertilizante [80] contribuiu muito para o aumento da produção e a 
sua sustentabilidade. Na área industrial a produção de energia térmica e elétrica, a partir do bagaço da cana, deu uma grande contribuição para a diminuição do $\mathrm{CO}_{2}$ gerado pelo ciclo do álcool (plantação, transporte, produção, utilização), sendo observada a captação de $\mathrm{CO}_{2}$ neste ciclo de 0,17 toneladas métricas para cada tonelada de cana processada [81].

Certamente não se deve ter a idéia de que o álcool poderá substituir totalmente os combustiveis fósseis, porém este se mostra como um bom produto para compor a matriz energética mundial, que deverá ser bem mais diversificada no futuro $[12,17,29,36]$.

Voltando rapidamente ao lado das pesquisas que tentam, de uma ou outra forma, contribuir para a mitigação da questão das emissões, pesquisas brasileiras criaram um interessante atributo para o álcool, além de combustível. É possível a produção de plásticos, que terá grande capacidade de reciclagem. $O$ ciclo de produção absorverá mais $\mathrm{CO}_{2}$ do que emitirá. A primeira planta alcoolquímica será instalada no Brasil através de uma parceria entre duas grandes empresas e tem sua previsão de inicio de produção para 2011. Esse produto se encaixa no conceito de berço a berço, o que poderá ser um grande avanço no caminho de produtos mais sustentáveis [82].

\subsection{Política}

Ações que diminuem o consumo energético através de melhorias de processo são sempre bem vindas, pois isso é o mesmo que construir usinas que não poluam a custo baixíssimo e manutenção praticamente nula. Isso requer um grande esforço técnico, mas, sobretudo político.

Um bom exemplo é o da prefeitura de São Paulo, que regulamentou a Lei $\mathrm{n}^{\circ} 14.459$ e obriga que toda construção com 3 banheiros ou mais a ter aquecedores solares. Isso inclui prédios comerciais além das residências. No caso dos comerciais, estão inclusas todas as atividades que tenham demanda de água aquecida. Isso pode parecer pouco, mas projetando para o futuro a economia de energia elétrica será bastante grande, principalmente nos horários chamados de pico [83]. 
Para que esta iniciativa seja melhorada, a prefeitura poderia subsidiar os aquecedores para as construções menores, mesmo as já existentes, para que se possa, em pouco tempo, aumentar a economia energética na cidade.

Existem formas de energia que em curto prazo poderiam diminuir muito as emissões de $\mathrm{CO}_{2}$ na atmosfera, entretanto enquanto os custos das externalidades não forem computados e incorporados ao seu preço, essas formas mais limpas de geração se manterão mais caras que as convencionais. No anexo C são mostrados os princípios básicos da formação de preços com e sem a incorporação das externalidades.

Muitos países possuem legislação específica para regulamentar as empresas que trabalham com processos geradores de resíduos tóxicos, porém o descumprimento dessas leis gerou, em muitos casos, graves conseqüências ambientais. O tratamento e destino de tais produtos deveriam ser mais que uma simples obrigação imposta por força de lei e sim uma prática comum dos processos industriais. São inúmeros os casos de empresas que contaminaram rios, solo e ar, causando graves doenças na população do entorno.

Todo esse problema fica para ser resolvido pelos órgãos de saúde pública, mantido com dinheiro de toda a população. Essa prática se dá por vários motivos, entre eles o desconhecimento da população sobre seus direitos, do desconhecimento da própria empresa sobre suas obrigações e, sobretudo, por má fé por parte da empresa. Caso essas externalidades fossem computadas ao custo dessas empresas, seria muito mais barato cuidar dos residuos do que simplesmente descartá-los (FIG.20 e 21).

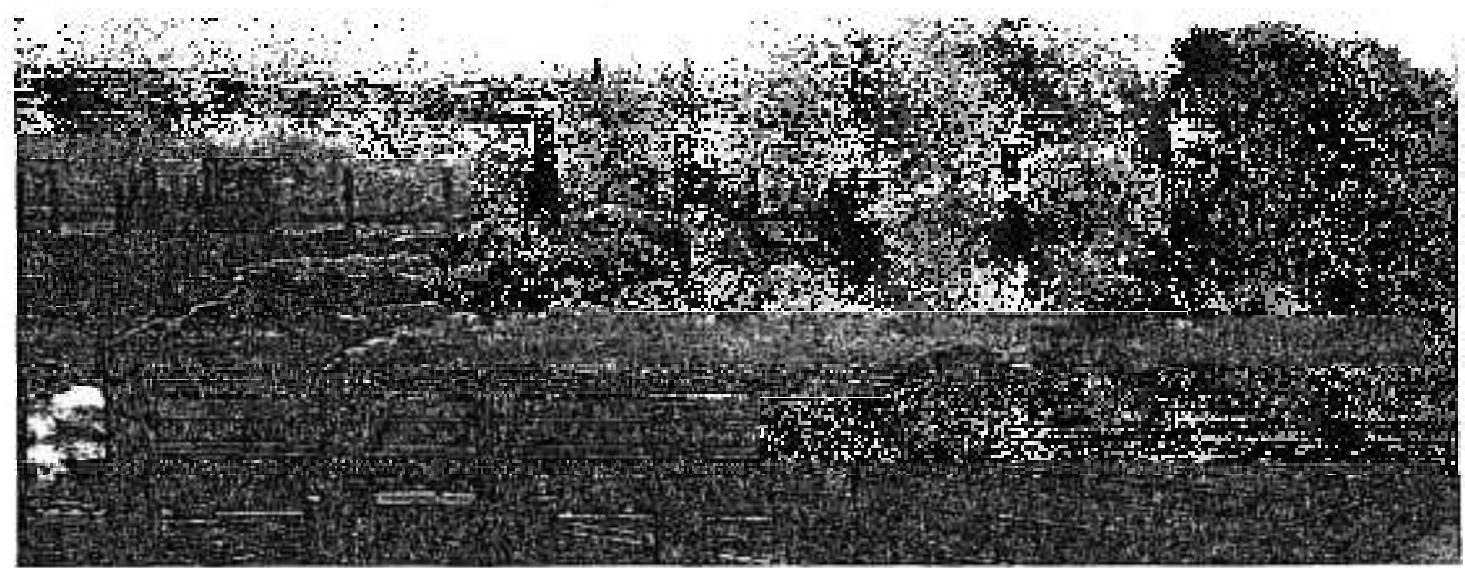

FIGURA 20 - Foto ilustrativa sobre poluição no mundo [84]. 


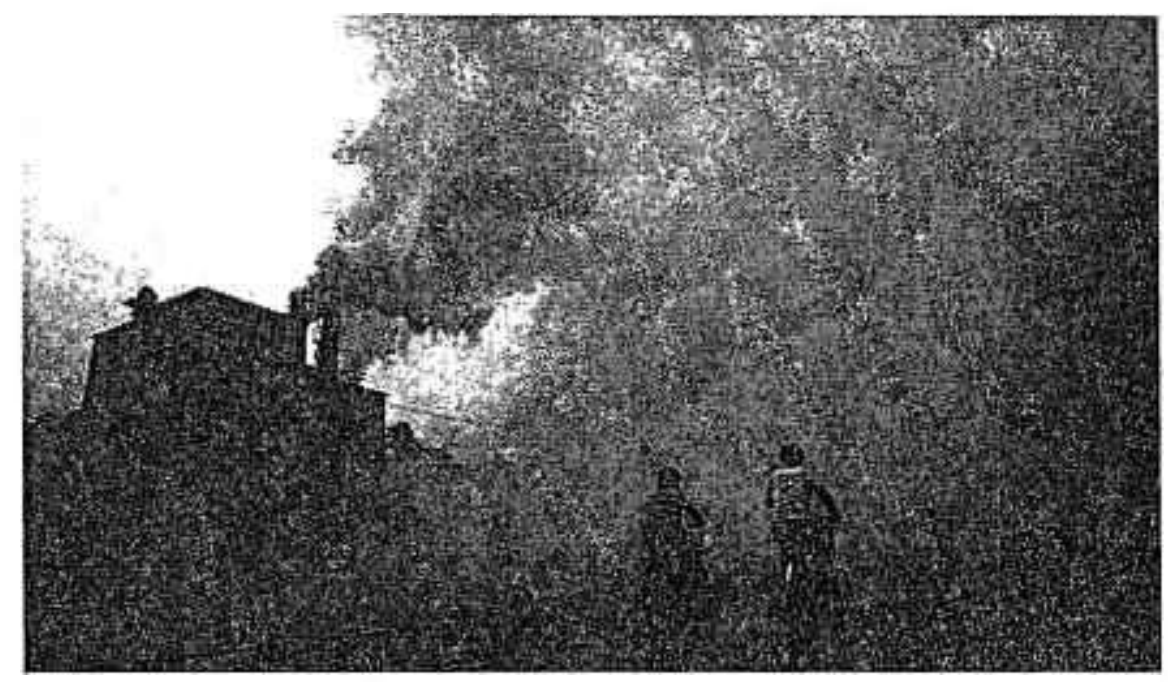

FIGURA 21 - Sobre o problema de poluição na cidade de Beijin e como isso poderá prejudicar a realização da maratona nas Olimpiadas de 2008 [85].

Esta última imagem faz parte de uma matéria onde o médico do Comitê Olímpico Inglês questiona a realização da prova da maratona na cidade de Beijin, uma das mais poluídas da China, por considerar que os atletas tenham dificuldade com o excesso de poluição no ar. Isso parece um fato isolado, porém as considerações e prejuízos da imagem da cidade podem ser irreversíveis, assim como os seus produtos no mercado internacional.

\subsection{Eco-economia}

A eco-economia é uma forma de implementação de políticas de desenvolvimento sustentável. O planeta é um sistema fechado, e o descarte é transformado em insumo de um novo processo, fechando-se um ciclo [86].

O ponto mais critico na para a implantação de uma eco-economia são os critérios que levam a tomada de decisão de se implementar um determinado empreendimento. Uma análise eco-econômica favorável seria o corolário dessa decisão. Essa análise deve levar em consideração vários fatores, alguns deles, muitas vezes, que não são dominados pelos tomadores de decisão. Assim esta análise deverá ser feita por um grupo de especialistas multidisciplinares.

Existem várias maneiras de se analisar um projeto sob o ponto de vista do eco-economia. Os métodos mais conhecidos são aqui descritos sucintamente: 
a) Avaliação do Impacto Ambiental -AIA (EIA - do inglês Environmental Impact Assessment) [87], que é geralmente definido como uma remuneração investida na comunidade e regulamentada por legislação local, sobre o impacto ambiental e sobre o bem estar humano avaliado, para um determinado projeto a ser instalado,

b) Avaliação Ambiental Estratégica -AAE (SEA - do inglês Strategic Environmental Assessment) [88], é, na verdade, apenas um aprimoramento e um complemento da AIA que leva em consideração o valor estratégico do projeto no dimensionamento da compensação,

c) Avaliação do Ciclo de Vida - ACV (LCA - do inglês Life Cycle Assessment) [89], foi influenciado e desenvolvido em paralelo aos métodos de análise energética que se seguiu à crise do petróleo na década de 70. ACV taxa o impacto ambiental de produtos e serviços durante toda a sua "vida" ("do berço ao túmulo"). Inclui extração do material bruto, a energia usada, resíduos liberados em todos os processos, eventos ligados a transportes, etc. Assim, o foco da taxação não está no produto ou serviço propriamente, mas na sua função. Aliás, definir bem a função é uma das mais importantes partes desse método,

d) Análise Posicional - AP (PA - do inglês Positional Analysis) [90], surgiu como tese de doutorado na década de 70 e visa levantar e elucidar todas as questões na elaboração de processos. Torna mais visível conflitos de interesses e pontos de vistas tornando mais democráticas as decisões,

e) Análise de Custo-Benefício - ACB (CBA - do inglês Cost-Benefit Analysis) [91], são de alguma maneira, feitas desde o século 19. Essa análise baseia-se na economia neoclássica que tenta estimar o impacto total de um projeto na comunidade, calculando os seus custos e os seus benefícios. Impactos ambientais foram incluídos nas estimativas, convertendo-os também em valores monetários. Utiliza-se conceitos como disposição de pagar, e disposição de aceitar, por perda eventual de bem estar,

f) Intensidade de Material por Unidade de Serviço - IMUS (MIPS - do inglês Material Intensity per Unit Service) [92], surgiu primeiramente na Alemanha por volta de 1992. O estudo da IMUS de um projeto (bem ou serviço) considera todo material usado e/ou processado conjuntamente. A contabilidade de material usado se dá ao longo de todo o tempo de vida do projeto desde a manufatura, 
passando pelo uso e reparos, até a disposição final ou eventual reciclagem. Resíduos e emissões não são diretamente tratados por esse método,

g) Necessidade Total de Material - NTM (TMR - do inglês Total Material Requirement) [93], é mais ou menos similar ao IMUS com a diferença que a contabilidade não é feita por unidade de serviço mas sim de forma regional,

h) Pegada Ecológica - PE (EF - do inglês Ecological Footprint), como já visto, é a área total necessária para produzir alimentos, energia e insumos e também eliminar a poluição (absorção de carbono, por exemplo) de cada ser humano de maneira sustentável (vide também anexo B),

i) Análise Exergética - (em inglês Exergy Analysis) [94], é usada em substituição a Análise Energética, pois esta muitas vezes não é uma medida adequada. Por exemplo, energia elétrica pode ser usada para executar um trabalho que a mesma quantidade de calor não pode executar. A exergia, assim, é uma medida da quantidade (e da "qualidade") de energia que é efetivamente transformada em trabalho,

j) Avaliação de Risco - TR (RA - do inglês Risk Assessment) [95], pode ser operado de diferentes maneiras. $O$ objetivo pode ser a saúde humana ou efeitos sobre o meio ambiente, e a fonte do risco pode ser difusa (dispersa) ou bem determinada (específica) além de operacional ou acidental e

k) Análise Emergética - (em inglês Emergy Analysis) [96], é baseado no conceito de sistema, no sentido termodinâmico, que é um grupo de partes que estão conectadas e trabalham juntas para um determinado fim, e no conceito de emergia que quer dizer energia incorporada. A análise emergética tem em si um profundo sentido de humanidade e de quase reverência ao meio ambiente, sem perder um minimo do rigor da análise científica.

\subsubsection{Imposto Internacional Para o Desenvolvimento}

A idéia de que as nações do mundo desenvolvido devem ajudar o desenvolvimento dos países pobres não é algo totalmente novo. O economista e ganhador do prêmio Nobel de 1981 [97], James Tobin, da Universidade de Yale, formulou a idéia da chamada Taxa Tobin. Esse tributo incidiria sobre as movimentações financeiras internacionais de caráter especulativo [98], com a 
finalidade de financiar o crescimento dos países pobres do mundo além das prioridades globais.

Mais recentemente, o ex-presidente francês, Jacques Chirac, sugeriu, numa reunião em 2006, que aos países mais desenvolvidos do mundo trabalhassem na idéia da criação de um imposto internacional que permita arrecadar 50 bilhões de dólares ao ano para ajudar os países pobres (revivendo a Taxa Tobin). [99]

Durante essa sessão de trabalho do G8 em Sea Island (sudeste dos Estados Unidos), Chirac declarou que faz falta "explorar sem tabus todos os mecanismos possíveis".

O presidente brasileiro Luís Inácio Lula da Silva sugeriu, também no ano de 2006, em posteriores reuniões, a criação de impostos internacionais sobre a venda de armamentos. Essa idéia foi defendia inclusive pelo presidente americano, porém esses impostos ainda terão um longo caminho a percorrer, para que se tornem realidade.

\subsubsection{Redução de emissões e Certificação Verde}

Com a Eco92, que estabeleceu as prioridades nas questões de sustentabilidade (econômica, ambiental e social), e em $1997 \mathrm{com}$ a assinatura do Protocolo de Quioto [13], (redução do $\mathrm{CO}_{2}$ em $5 \%$ considerando os níveis de 1990), começou a se difundir os mecanismos de flexibilização de emissões, tais como: I - Comércio de cotas de emissões entre nações desenvolvidas, II Transferência de cotas de emissões entre nações desenvolvidas vinculadas aos projetos específicos de redução de emissões e Ill - Mecanismo de Desenvolvimento Limpo - MDL, esta última uma proposta do Brasil [100].

Os MDLs são a forma dos países em desenvolvimento poderem participar do estabelecido em Quioto. Trata-se de projetos que evitem ou seqüestrem $\mathrm{CO}_{2}$, da atmosfera. Contudo devem estar dentro das normas estabelecidas pelos organismos competentes.

Após as devidas aferições e certificações, as toneladas absorvidas ou evitadas, são transformadas em títulos e negociadas em bolsa, também chamados de créditos de carbono. 
O crédito de carbono serve para empresas de país constantes no Anexo 1 do protocolo de Quioto (países desenvolvidos), para contar como meta alcançada, ou seja, o país debita esse crédito da sua cota.

Outra forma que contribuir para a redução das emissões são as chamadas Certificações Verdes. Muito em uso nos países europeus mais desenvolvidos, essas certificações normalmente obedecem a normas internacionais de produção e devem ser atestadas por entidades credenciadas.

A primeira impressão leva a pensar que isso seria uma forma de garantia de mercado. Porém é mais uma forma de ajuste e consciência ambiental que qualquer outra coisa. Como são exigidas das empresas domésticas atitudes ambientais, nada mais justo que exigir o mesmo das empresas de outros países.

\subsubsection{Acondicionamento de produtos (embalagens)}

Um item de grande importância quando se fala em consumo, é o setor de embalagem. Praticamente todo o produto (endereçado para o consumidor final) necessita ser embalado e, na maioria dos casos, essas embalagens são produzidas de derivados de petróleo. Apenas por esse motivo já seria um problema, aliado ao fato que quando descartadas contribuem para o grande volume de lixo gerado principalmente nas cidades.

Algumas tecnologias estão sendo desenvolvidas para que esse problema diminua. A instalação do primeiro pólo alcooquímico do mundo será no Brasil. Produzirá plástico utilizando a cana-de-açúcar como matéria prima. 0 plástico produzido por esse processo será altamente reciclável, o que é desejável, e contribuirá para a diminuição do volume de lixo gerado pelos consumidores.

Outra linha de pesquisa que está com trabalhos bastante avançados, é a produção de embalagens biodegradáveis e comestíveis a partir do amido. Neste último caso a matéria prima é extraída da mandioca. São produtos que imitam o plástico, os quais foram chamados de biopolímeros.

Para a fabricação dos biopolímeros é utilizada a fécula de mandioca. Produto muito tradicional em todos os cantos do Brasil, as possibilidades desses produtos para o ramo de embalagens, são imensas. Primeiramente por serem biodegradáveis não poluem, pois se decompõem rapidamente, em alguns casos estes produtos podem dar origem a embalagens que poderão ser ingeridas, e 
neste caso a possibilidade de se reduzir a quantidade de lixo é grande, além da eliminação do risco de acidentes por ingestão de embalagem [101].

Vale destacar o caso dos recipientes de alumínio usados para embalar cervejas e refrigerantes. Como já foi mencionada anteriormente, em muitos países a taxa de reciclagem desse tipo de embalagem chega perto de $80 \%$ (Brasil e Japão). Esse tipo de reciclagem tem um impacto direto no custo ambiental, pois se economiza cerca de $80 \%$ do consumo de energia necessário para produzir as embalagens pelo método tradicional.

Em termos de destino das embalagens de produtos tóxicos, é de grande valia o que o governo brasileiro tem feito com as embalagens de agrotóxicos usados na agricultura. Primeiramente foi realizada uma campanha de conscientização dos agricultores sobre a forma de lavar e estocar as embalagens até que fossem retiradas, de acordo com a lei, pelas empresas que fornecem esse tipo de produto. Estas, por sua vez, têm a obrigação de cuidar do descarte dessas embalagens. Isso contribuiu muito para a diminuição da poluição dos rios, pois em muitos casos essas embalagens eram descartadas sem nenhum critério.

\subsubsection{Mundo "verde-rosa"}

Para que o mundo dê os primeiros passos no caminho de uma sociedade sustentável, devem-se valorizar as primeiras ações nesse sentido. Muitas ações já foram feitas ou estão sendo executadas, como é o caso da Vila de Dangtan, cidade chinesa que está em construção e deverá ser a primeira cidade ecológica do mundo em 2010. A cidade está programada para receber cerca de 10.000 habitantes na primeira fase de construção e 500.000 até 2050 [69] Suas principais características são:

\section{- vida sem carro}

- "Todas as casas estarão no máximo a 7 minutos a pé de meios de transporte público, e com fácil acesso a escolas, hospitais e locais de trabalho,"

- "Os únicos veículos aceitos serão bicicletas ou movidos a combustiveis limpos - como bateria e células de hidrogênio." 


\section{- energia limpa}

-A energia virá de fontes renováveis, sobretudo da biomassa de casca de arroz e dos ventos,

- Os prédios terão até seis andares, para dispensar elevadores. O uso da energia solar e a circulação de ar permitirão economizar $70 \%$ da energia em geral usada para climatização.

\section{- menos lixo}

- "Cerca de $80 \%$ dos resíduos sólidos serão reaproveitados. O lixo orgânico será usado para a produção de energia",

- "Um sistema de reaproveitamento da água (usada para descargas e irrigação) vai reduzir o consumo desse recurso à metade" [87].

O termo "verde-rosa" é uma alusão que atualmente está sendo usado para um mundo ecologicamente equilibrado (verde) dentro de uma sociedade igualitária, em referência a um socialismo democrático (rosa).

\subsubsection{Novos Paradigmas da sociedade moderna}

Além de todos os grupos de ações em direção à sustentabilidade (educação, pesquisa, rejeitos, energia, política e recuperação ambiental), é sugerida outra ação, que na verdade e uma ação integradora entre educação e política, no sentido da incorporação nas sociedades de um novo paradigma de vida, tendo a felicidade, no seu conceito mais amplo, como meta. Essa ação integradora necessita ainda ser definida. Contudo cabe aqui uma consideração sobre essa necessidade.

Pesquisas sobre tomada de decisão [102], demonstraram que, de maneira geral, as pessoas são mais sensiveis às perdas do que aos ganhos. Mais que isso, o número de escolhas que uma pessoa pode fazer (que está ligada ao seu poder de compra), produz emoções positivas que aumentam atingindo um máximo, a partir daí o aumento das escolhas se estabiliza e começa a cair até ao nível das emoções negativas. O gráfico da FIG. 22 abaixo exemplifica esse processo. 


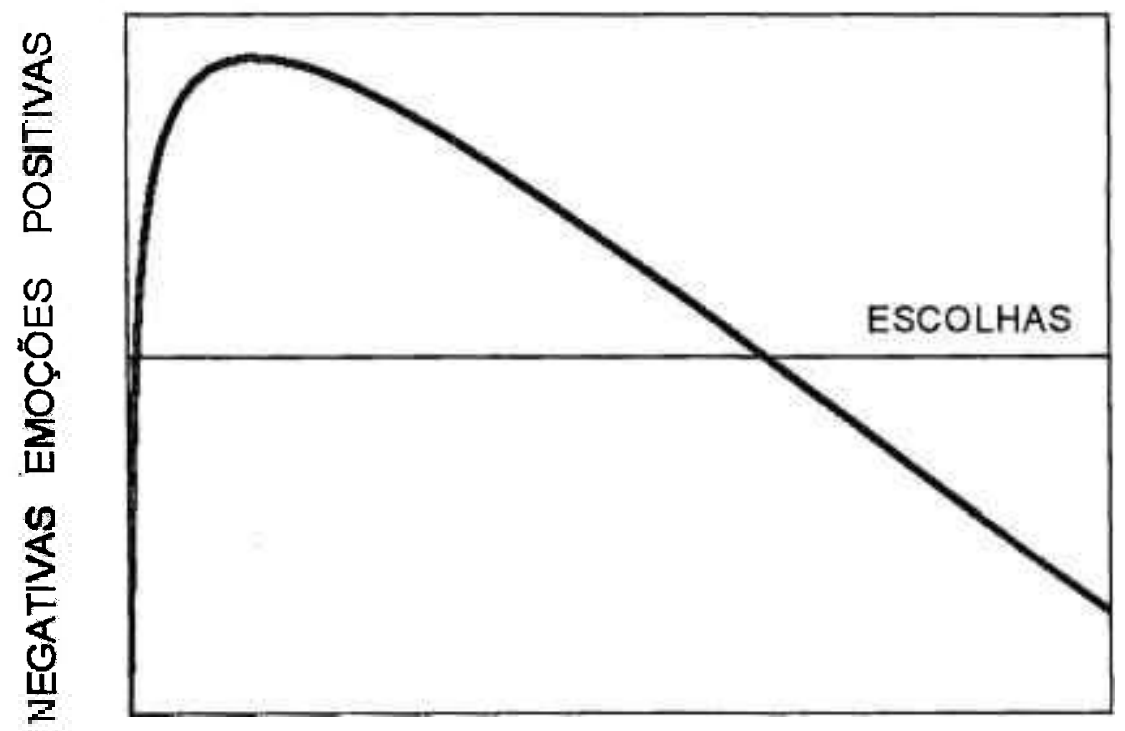

FIGURA 22 - Variação nas emoções em função do número de escolhas.

Ainda neste contexto, a fundação "New Economic" [103], elaborou uma métrica inovadora que mostra a "eficiência ecológica" com a qual o bem estar humano é medido. É um índice multidimensional, composto por variáveis que refletem diferentes aspectos da condição humana. Tem o nome de "Índice de Felicidade do Planeta (HPI na sigla em inglês - Anexo B), pois é determinado para todos os países.

É interessante relacionar o $\mathrm{HPI}$ com o IDH, como mostra a FIG.23 abaixo. 


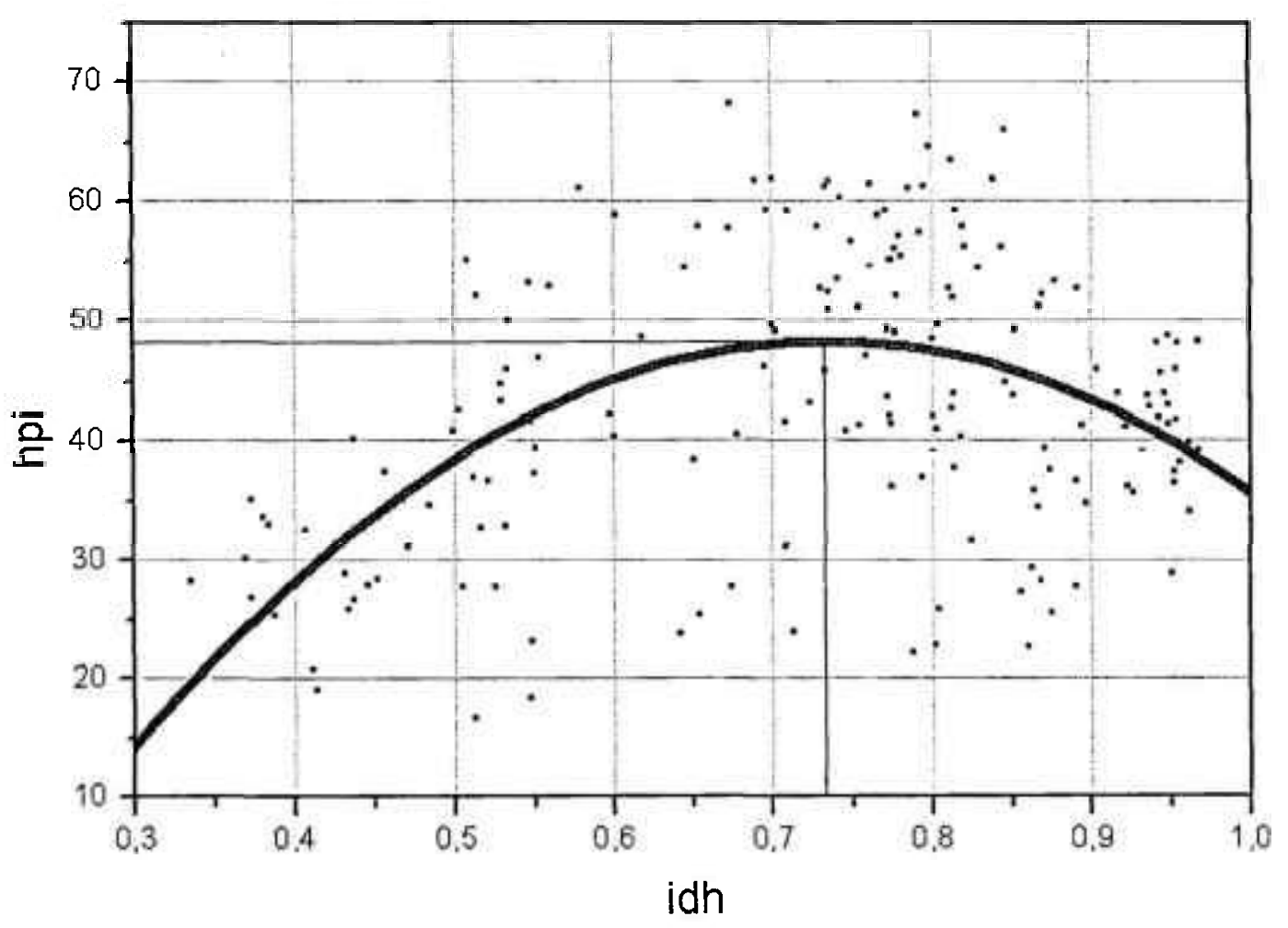

FIGURA 23 - Variação do HPI em função do IDH.

Observa-se que países com IDH entre 0,7 e 0,85 (faixa que inclui a fronteira entre o médio e alto IDH - 0,8) apresentam maiores HPI. Sem analisar as causas desse comportamento, apenas constatando este fato, mais uma vez é corroborada a necessidade de um novo paradigma para a vida. Na realidade um novo modelo de estilo de vida, deve se incorporar à sociedade, onde possibilite uma vida sustentável do ponto de vista ambiental, econômico, social e pessoal, para que as pessoas possam de fato exercer seu direito a uma vida mais feliz.

\subsection{RECUPERAÇÃO AMBIENTAL}

A degradação de uma área é determinada quando:

a) a vegetação e, em razão disto, também a fauna, são destruídas, removidas ou expulsas; e

b) a camada fértil do solo é comprometida, eliminada ou coberta, afetando a qualidade ambiental tanto da superfície quanto do subsolo. 
Em vistas disso, há alteração das características físicas, químicas e biológicas da área, afetando seu potencial sócio-econômico.

A recuperação se dá através da definição de um plano que considere os aspectos ambientais, estéticos e sociais, de acordo com a destinação que se pretende dar à área, permitindo um novo equilibrio ecológico.

A recuperação ambiental é uma necessidade contemporânea $e$ imposta por lei. Técnicas tradicionais de recuperação de áreas degradadas têm, no entanto, exposto ecossistemas naturais a riscos de contaminação biológica uma vez que muitas dessas práticas utilizam espécies exóticas. Neste trabalho não se abordará essas técnicas. $O$ importante é salientar que elas estão em franco desenvolvimento, tendo em viștas as determinações do Protocolo de Quioto que instituiu os chamados Mecanismos de Desenvolvimento Limpo (MDL) e as Reduções Certificadas de Emissões (item 7.5.3).

A questão da recuperação de áreas devastadas é por si só uma tarefa bastante difícil, pois estas se encontram em lugares que normalmente estão sendo usados para o plantio de grãos ou pastagens, e nestes casos os posseiros só saem da terra quando esta já perdeu toda a força produtiva.

Entretanto o professor Azirs Ab Sab, um dos maiores conhecedores dos biomas brasileiros, em suas palestras, ou mesmo em suas entrevistas [104], costuma dizer que o primeiro passo é conseguir criar uma forma de integrar o homem a terra já devastada. Porém esta população teria que ter um grande preparo e assistência por parte do governo para poder criar uma área de entorno da floresta que possa contribuir para a sua preservação, e não deixando de estar integrada ao homem.

Outra forma de recuperação de áreas devastadas é o reflorestamento comercial, que tem como objetivo o plantio de arvores para a produção de celulose ou mesmo para o comércio de madeiras. Existem vários defensores desse tipo de atividade assim como muitos críticos, porém não se pode descartar tal empreendimento, pois não deixa de ser uma forma de seqüestro de $\mathrm{CO}_{2}$, porém não se pode dizer que seria a melhor forma de se recriar um bioma. 


\section{CONCLUSÕES E SUGESTÃO}

Confrontando números e gráficos relativos aos índices acima relacionados, pode-se, de maneira genérica, resumir o exposto da seguinte forma:

$\Rightarrow$ o consumo de insumos no mundo vem crescendo de forma contínua, cuja parcela relativa ao ciclo da energia corresponde a maior parte. Esse consumo já superou em muito $(\sim 16 \%)$ o limite da sustentabilidade e se deve basicamente ao terço mais rico da população mundial $(1,7$ bilhão de pessoas), que não está necessariamente apenas nos países ricos. Verificase também que grande parte desse consumo, muitas vezes pode ser considerado supérfluo quando, ao mesmo tempo, necessidades vitais urgentes não são atendidas. Ao mesmo tempo esse consumo contribui fortemente para os atuais problemas ambientais globais,

$\Rightarrow$ o sistema hegemônico vigente (capitalismo), devido à sua própria lógica, parece que só levará em conta a sustentabilidade sócio-ambiental quando esta se tornar um "bom negócio". No entanto a premência de ações é tal, que talvez esta espera leve a humanidade ao colapso,

$\Rightarrow$ a partir de um determinado nível de desenvolvimento econômico e social, os níveis de degradação ambiental, de uma determinada economia, começam a melhorar e grande parte dessa recuperação ambiental constatada nos países ricos se deve, através de diversos mecanismos, à transferência do ônus (ambiental e social) para os países pobres que podem com isso, comprometer definitivamente seu próprio desenvolvimento. Outra parte dessa recuperação ambiental é devida aos efeitos internos de escala, composição e tecnologia além da contribuição correspondente a Intensidade Energética decrescente. Destaca-se, pois, que já estão disponíveis as tecnologias necessárias para uma sociedade 
ambientalmente sustentável. A conscientização da população também é um fator incentivador nesse processo,

$\Rightarrow$ um novo "estilo" de vida deverá ser incutido nas sociedades, mesmo porque, como foi visto, a satisfação pessoal e a qualidade de vida não é, a partir de um certo ponto, função direta da multiplicidade das escolhas,

$\Rightarrow$ a implementação dos 6 grupos de ações sugeridas aqui (educação, pesquisa, rejeitos, energia, política e recuperação ambiental) e, de alguma forma, uma política que leve à diminuição dos índices de corrupção, pode contribuir de maneira definitiva para começar a mudar o atual estado do mundo, seja no âmbito econômico, ambiental e principalmente social.

Ademais, quando se constata que as tecnologias e os recursos necessários para a implementação dessas ações de mudanças já existem, faltando apenas a vontade política para que isso aconteça, fica a questão: como então desencadear esse processo?

Este trabalho não tem a pretensão de responder de forma taxativa a essa questão. Porém algumas reflexões podem delinear os caminhos. É necessário criar um círculo virtuoso de médio e longo prazo para começar a mudar o mundo o mais rapidamente possível. $O$ foco inicial dessas ações sugerese que seja na Educação e na Pesquisa. Ninguém que tenha refletido, um pouco que seja, sobre esses problemas irá discordar dessa afirmação. Também não é possível isolar as nações ricas das pobres como vêm se verificando nas últimas décadas. Apenas para citar os problemas ambientais, estes estão adquirindo dimensões globais e as soluções, portanto devem ser também globais. Isso implica em solução, entre outras ações, dos problemas não ambientais, que só serão possíveis com um rearranjo do estilo de vida de todas as sociedades. Caso contrário corre-se o risco de se inviabilizar a vida futura no planeta. Ações pontuais são importantes, mas a proporção da ação necessária é de tal monta que é preciso mais que um conjunto de ações, é premente uma Revolução. Assim como a Revolução Industrial do século XVIII foi um divisor de águas na história, dado o impacto produzido, afirma-se aqui a necessidade dessa nova 
Revolução que, uma vez realizada, será com maior razão ainda, outro divisor de águas na história humana.

Cabe aqui reproduzir trecho da reflexão do diretor presidente do Instituto Akatu pelo Consumo Consciente, Dr. Helio Mattar, publicado no jornal Folha de São Paulo em 3 de Janeiro de 2008, cujo titulo é: CONSUMO COMO ATO DE SOLIDARIEDADE [105].

"Ao remexer alguns velhos papéis no final do ano, encontrei minhas anotações referentes a uma entrevista concedida pelo grande pianista canadense Glenn Gould. Foi na década de 60, não sei precisar o ano; na ocasião, ela me tocou tanto que me dei ao trabalho de traduzi-la para o português. Ao relê-la, fui tomado novamente pela mesma emoção e percebo, não sem um certo pesar, que quase nada mudou ao longo do tempo. Senti o mesmo completo desalento ao dar-me conta da enorme confusão em que vivia o mundo então e nos dias de hoje."

"Parecemos esquecer que, a cada segundo, vivemos um novo e único momento do universo, um momento que nunca antes existiu e que nunca existirá novamente. Parecemos esquecer que vivemos um milagre cotidiano. Tratamos o mundo como se fosse absolutamente evidente, sem mistério."

"Basta ver o que ensinamos a nossos filhos nas escolas. Ensinamos que dois e dois são quatro e que a capital do Brasil é Brasília. Quando passaremos a também ensinar o que eles são? Deveríamos dizer a cada um deles: você sabe o que você é? E então contar: você é uma maravilha! Você é único! Em todo o mundo, não há nenhuma outra criança exatamente como você. Você é mesmo um milagre!"

"Todos somos milagres. No entanto, crescemos e esquecemos. Passamos a nos ver de forma deturpada. De um lado, nós nos vemos apenas como pequenos átomos do universo, perdidos no infinito e sem condições de fazer qualquer diferença. Ou, então, nós nos imbuímos de enorme onipotência, como se nossa transformação em maravilha humana não fosse durar mais do que apenas um flash de tempo." 
"E então nos machucamos e machucamos outros. Enfrentamos nossas carências $e$ inseguranças buscando apenas a felicidade material, que é absolutamente fugaz e perecível, além do que, agora sabemos, insustentável."

"Esquecemos que todos os humanos foram produzidos por um milagre idêntico ao que nos produziu. $E$, por esquecer, construimos um mundo de enormes conflitos e de disputas desumanas."

"Precisamos nos convencer de que o mundo somos todos nós. E, se há sofrimento de muitos, esse sofrimento é também de cada um, pois todos dependemos de todos. Se a pobreza é muita, não há forma dessa pobreza não atingir mesmo os que não a vivenciam. Se a vida no planeta vier a perecer, tragada pelo aquecimento global que já mostra suas garras ferozes, nenhum de nós terá nenhum privilégio na escolha divina ou terrena e pereceremos também."

"Por tudo isso, a cada dia, devemos fazer algo pelos outros, saindo do egoísmo de cuidar apenas de nós mesmos. $E$ temos todos, à nossa frente, um conjunto de ações que poderiam representar uma grande contribuição para mudar o mundo."

"Por incrivel que pareça, ao consumir-comprar, usar ou descartar produtos ou serviços, podemos tentar impactar positivamente a sociedade e o planeta em um ato voluntário e cotidiano ao alcance de qualquer um, quase sem esforço."

"Ao não desperdiçarmos recursos naturais; ao comprarmos produtos de empresas que investem em comunidades, funcionários e meio ambiente; ao preferirmos comprar de cooperativas de economia solidária; ao usarmos o que temos até que tenha esgotado a sua vida útil; ao nos perguntar, a cada compra, se realmente precisamos do que vamos comprar; ao usarmos o que compramos com profundo respeito pelo fato de o produto conter parte da natureza em suas matérias-primas, água e energia; ao descartarmos o que não serve mais para ser usado, buscando reciclar ao máximo tudo o que for reaproveitável; em cada um desses gestos, pequenos gestos, estaremos, voluntária e cotidianamente, fazendo algo pelos outros, e não apenas por nós mesmos."

"Ao consumirmos com consciência, buscando maximizar os impactos positivos de nossos atos de consumo, estaremos beneficiando a economia, a 
sociedade ou o meio ambiente e, portanto, fazendo um mundo melhor por meio de nossos atos de consumo."

"E assim, ao final de cada dia, quando cada um de nós se perguntar sobre o que fez hoje para melhorar a vida dos que sofrem, dos que estão impedidos de se realizarem minimamente como humanos, para melhorar as condições ambientais para que a vida possa continuar em nosso planeta, teremos uma resposta. Teremos consumido com nossa consciência voltada para os outros, e não somente para nós mesmos, tornando o consumo um ato de solidariedade."

Verificam-se ações positivas em andamento pelo mundo de várias intensidades e focos. De fato existem essas preocupações nos vários níveis das sociedades e em todas elas. Contudo um elemento desencadeador incontestável deverá surgir de modo a tornar o processo de fundação de um Novo Mundo irreversivel. Mais uma vez não é pretensão deste trabalho identificá-lo. "Porém sabe-se que esse elemento desencadeador poderá ser de dois tipos: ou "suave", como as ações sugeridas no trabalho, ou traumáticas" como as previsões do Pentágono descritas no capítulo 6.

Por fim, como sugestão para um futuro trabalho, é proposta uma avaliação estimando as evoluções de alguns indicadores, como, por exemplo, os vistos no trabalho: economia nas emissões de $\mathrm{CO}_{2}$, "FootPrint", $\mathrm{ESI}, \mathrm{IDH}$, Índice Gini, aprofundamento nas relações de eficiência energética e lixo etc., quando da efetivação das ações aqui propostas no capítulo 7 (educação, pesquisa, rejeitos, energia, política e recuperação ambiental) em uma certa comunidade padrão real ou ideal.

É evidente que grande parte das ações rumo a essa sociedade sustentável vai depender de políticas e ações a nível nacional e mesmo a nível global. Porém essa dependência pode ser prevista, da maneira a mais realista possível, e então utilizadas conjuntamente com as ações aqui propostas. O prazo aproximado de implantação pode ser aquele em que se estima ser uma geração, ou seja, em um horizonte de 20 anos. Muitos exemplos de mudanças sociais e ambientais se deram aproximadamente neste intervalo de tempo. 


\section{ANEXO A - Histórico dos eventos chaves que despertaram a atenção para as questões sócio/ambientais globais (1960 a 2007).}

(O histórico a seguir baseou-se no histórico de abertura do relatório do Instituto WWF "O Estado do Mundo 2005". [36])

1962 -TóxICOS - Publicação do livro Primavera Silenciosa (Silent Spring), de Rachel Carson, que chamou a atenção para as emissões de elementos tóxicos que prejudicavam o a população e o meio ambiente.

1967 - POLUIÇÃO - Acidente com petroleiro Torrey Canyon derramou 117.000 toneladas de petróleo no Mar do Norte perto de Carnwall, os proprietários do navio foram responsabilizadas legalmente pelos grandes danos ambientais.

1967 -GOVERNO - Estudiosos do mundo encontraram-se na conferencia das Nações Unidas sobre Biosfera França, para discutir problemas ambientais, escassez de recursos, poluição e destruição das florestas.

1968 - POPULAÇÃO - Paul Ehrich publicou A bomba populacional (The Population Bomb), discutindo sobre população e ecologia.

1970 - GOVERNO - Milhares de pessoas reuniram-se nos EUA para o primeiro Dia da Terra (Earth Day) para protestar contra os abusos contra o meio ambiente e exigir a criação de leis que protejam o meio ambiente assim como as espécies e a água potável.

1971 -GOVERNO - 2.200 cientistas reuniram-se na cidade de Menton, França, onde foi enviada para a ONU uma mensagem que alertava da urgência de uma união de esforços globais para as questões ambientais e sociais do planeta. 
1972 - POLUIÇÃO - Relatório de pesquisas demonstra que três quartos de toda a chuva ácida da Suécia é causada por poluição oriunda de outros países.

1972 - CONSUMO - O Clube de Roma, um grupo de cientistas, economistas e lideres de negócios de 25 países, publicaram o relatório "Os limites do crescimento", que tratava dos recursos naturais durante os próximos 100 anos, considerando as taxas de crescimento da população, da utilização dos recursos naturais e de emissão de poluição.

1972 - GOVERNO - Conferência das Nações Unidas sobre Meio Ambiente, em Estocolmo, Suécia, com participação de 114 países. Somente um pai tem um ministério do Meio Ambiente, poucos paises não têm nenhuma agência ambiental. Os 109 delegados recomendaram para seus governantes, ações para que fosse instaurado um Programa das UN para o meio ambiente.

1972 - GOVERNO - A economista Bárbara Ward e o microbiologista René Dubos publicam "Somente uma Terra" (Only One Earth) que adverte que as ações da humanidade estão minando as Habilidades do Planeta de sustentabilidade.

1973 - ETNIAS - Mulheres que vivem no Himalaia e no norte da Índia começam o movimento Chipko para proteger árvores da exploração comercial, que causou severo desflorestamento, erosão do solo e inundações na região.

1973 - BIODVERSIDADE - A convenção Internacional sobre Espécies da Fauna e da Flora (CITES), informa a necessidade restringir o comércio ilegal de amimais e plantas silvestres, pois essa atividade coloca em risco de extinção aproximadamente 5.000 espécies de amimais e 25.000 espécies de plantas, estimasse que esse tipo de comercio movimente 1 bilhão de dólares. 
1973 - ENERGIA - Países Árabes membros da Organização dos Países produtores de Petróleo (OPEC), reduzem a exportação de petróleo para Europa e fazem embargo contra os EUA por apoiar a guerra de Israel contra a Síria e o Egito.

1973 - POLUIÇÃO - A Convenção para a prevenção da poluição dos navios, que adotou medidas para restringir as emissões poluentes dos navios e eliminação do lixo, orgânico, plásticas e água usada nos serviços de limpeza em geral, assim como normas para prevenir possiveis vazamentos de óleo.

1974 - CANADA DE OZÔNIO - Os Químicos, Sherwood Rowland e Mario Molina publicam artigos que afirmam que os clorofluorcabonetos (CFCs) destroem a camada de ozônio que protege a terra dos raios solares.

1974 - WORLDWATCH INSTITUTE - O ambientalista Lester Brawn funda um instituto de pesquisas independente, para trabalhar as questões ambientais, sustentabilidade de justiça social.

1976 - URBANIZAÇÃo - Participantes da Conferência sobre Habitação Humana, em Vancouver, Canadá, concordaram que moradia é um direito basco do ser humano e redigiram 65 recomendações para os países providenciar tal medida.

1977 - ETNIAS- Indígenas protestam nas Filipinas e forçam o Banco Mundial a retirar o financiamento para a construção de quatro grandes barragens ao longo do rio Chico. Desse esforço para bloquear os projetos, emergiu um movimento global para proteger os rios e resistir a construção de grandes barragens.

1979 - POLUIÇÃo - A Convenção sobre o longo alcance da poluição através do ar, que ajudou a combater a chuva ácida e regularizaram as emissões de vários gases poluidores, metais pesados, poluentes orgânicos, assim como diversos outros poluidores. 
1979 - POLUIÇÃO - Acidente ocorrido na Usina Nuclear de Three Mile Island, na Pensilvânia, EUA, onde o núcleo do reator derreteu e espalhou radiação para as comunidades ao redor.

1981 - SAÚDE - O vírus da AIDS é detectado em estudos clínicos. Passado duas décadas, o vírus se espalhou pelo mundo, matando milhões de pessoas, o que fez que muitos países implementassem políticas para frear $o$ avanço.

1982 - GOVERNO - O programa das Nações Unidas organizou a Estocolmo+10, conferencia realizada em Nairóbi. Os participantes em comum acordo fizeram uma declaração que expressa a grande preocupação com o meio ambiente e estabelecem uma comissão independente para criar uma agenda que mude as atuais tendências, para traçar um futuro comum, na próxima conferencia em 1987.

1982 - OCEANOS - A convenção da lei dos mares, ajusta toda a estrutura do uso e conservação dos oceanos, prevenção da poluição e proteção e restauração das populações das diferentes espécies.

1982 - ECONOMIA - México, e outros países em desenvolvimento junto com o bloco de países do Oriente, fecharam empréstimos internacionais de $\$ 250$ bilhões de dólares, diminuindo a crise. Os empréstimos foram feitos para evitar futuras crises.

1983 - CLIMA - A agência Americana de proteção ao meio ambiente, e a Nacional Academia de Ciências do EUA concluíram através de relatórios que as crescentes taxas de dióxido de carbono e outros "gases de efeito estufa" da atmosfera da Terra poderiam provocar um aquecimento global.

1984 - TOXIDADE - Estima-se que 10.000 pessoas morreram e muitas mais foram feridas quando a fábrica de pesticidas da "Union Carbide" derramou 40 toneladas de gases tóxicos no ar emitindo uma nuvem de veneno de para cidades circunvizinhas de 1 milhão de habitantes. 
1985 - CAMADA DE OZÔNIO - Cientistas reportam a descoberta de um buraco na camaḍa de ozônio, com dados examinados na Antártica Britânica, percebeu-se uma diminuição de 10 por cento em comparação ao ano anterior.

1986 - POLUIÇÃO - Um dos quatro reatores nucelares da usina soviética de Chernobyl explodiu e derreteu-se completamente. A explosão mandou partículas radioativas para toda a Europa Oriental, expondo milhões de pessoas a pesados niveis de radiação.

1987 - GOVERNO - No Protocolo de Montreal, que trata sobre substâncias que esgotam a camada de ozônio, os participantes planejaram as medidas para que se reduza a produção de gases que afetem a camada de ozônio.

1987 - GOVERNO - A Comissão Mundial do Meio Ambiente e Desenvolvimento publicaram "Nosso Futuro Comum" (O Relatório Brundtand), com conclusões que a preservação do meio ambiente a luta contra a pobreza poderia promover o desenvolvimento econômico sustentável.

1988 - FLORESTAS - O trabalhador rural e ambientalista Chico Mendes morre assassinado por fazendeiros. Representando 70.000 seringueiros, Mendes contribuiu para o uso sustentável das florestas brasileiras é melhor que usar a madeira ou desmatar para a agricultura ou pastagem. $O$ fato chamou a atenção internacional para o desmatamento das florestas tropicais.

1988 - BIODIVERSIDADE - O biólogo O. Wilson publicou uma coleção de relatórios do Fórum Nacional de Biodiversidade nos EUA, intitulado Biodiversidade (Biodiversity). O livro detalha como a raça humana esta acabando com os recursos naturais do planeta eliminando rapidamente a capacidade que a Terra tem de suportar a diversidade de espécies que existem. 
1989 - POLUIÇÃO - O petroleiro Exxon Waldez acidentou-se nos recifes de Prince Willian Sound, Alaska, EUA, derramando 76.000 toneladas de óleo cru. O maior acidente desse tipo nos EUA, a mancha de óleo cobriu 5.100 quilômetros de costa e matou mais de 250.000 aves.

1989 - Tóxıcos - A convenção da Basiléia, que controla o movimento de resíduos perigosos através de barreiras internacionais, é adotada para impedir que sejam enviados resíduos industriais tóxicos dos países industrializados para os países em desenvolvimento.

1991 - SEGURANÇA - O exército do Iraque recuou da ocupação do Kuwait, destruindo tanques, terminais de petróleo, através de incêndios. A luta e a sabotagem derramaram cerca de 1,25 milhões de toneladas de óleo, o pior derramamento da história.

1992 - CLIMA - A convenção das Mudanças Climáticas, fixou metas de redução de emissões de dióxido de carbono para os países industrializados (níveis de 1990 até 2000). O tratado final chamou para que se diminua o deleite humano que esta causando as alterações climáticas, mas as expectativas em curto prazo não são boas devido ao pouco interesse dos Estados Unidos.

1992 - BIODIVERSIDADE - A Convenção da Diversidade Biológica serviu para que os países formulassem estratégias para proteger a biodiversidade $\mathrm{e}$ para os países industrializados ajudassem a implementar essas estratégias nos países em desenvolvimento.

1992 - GOVERNO - A reunião da "Union of Concerned Scientists" reuniu 1.700 cientistas, que advertiram que os seres humanos e o mundo natural estão em rota de colisão.

1992 - GOVERNO - Líderes de 117 países participaram da Conferência do Meio Ambiente e Desenvolvimento, organizada pelas Nações Unidas, (Cúpula da Terra), no Rio de Janeiro, Brasil. Participantes adotaram a Agenda 21, 
um volumoso projeto para o desenvolvimento sustentável que serve para melhorar a qualidade de vida na Terra.

1994 - ESPÉCIES EM PERIGO - A União Mundial de Conservação publicou uma revista com a "lista vermelha" com centenas de espécies em perigo de extinção, criando um padrão para que o mundo trate a biodiversidade. Outras versões do relatório relatam que uma em cada 4 espécies de mamíferos e uma a cada 8 espécies de pássaros correm risco de extinção em um futuro próximo.

1994 - POPULAÇÃO - Delegados de 183 países encontraram-se na Conferência sobre População e Desenvolvimento na cidade do Cairo, Egito, e ajustaram um plano para estabilizar o crescimento populacional. O plano enfatiza a importância da educação das mulheres, e acesso ao sistema de saúde para os nascimentos.

1995 - POPULAÇÃO - Representantes de 180 países encontraram-se na Conferência das Mulheres em Beijing, China, para preparar uma agenda para melhorar a vida de mulheres e meninas. Na resolução constam ações para reduzir a erosão do solo, desflorestamento e outras formas de degradação ambiental que podem afetar os proventos das mulheres e seus familiares.

1995 - CLIMA - O Painel Intergovernamental de Mudanças Climáticas (IPCC), um grupo reunido pelas ONU 1988, composto de lideranças científicas das questões do clima, apresentam um relatório conclusivo que diz "o balanço de evidências indicam que as influencia humana tem influencia sobre o clima".

1995 - ETNIAS - Escritor e ativista Ken Saro-Wiva foi enforcado na Nigéria, por liderar o povo Ogani contra as companhias de petróleo: Royal Dutch/Shell e Cheron entre outras, pela destruição das terras de seu povo. 
1996 - TóxıCOS - Theo Calborn, Dianne Dumanoski e Peter Myers, publicaram "O nosso futuro roubado", o qual adverte das ameaças da reprodução dos animais - incluindo o homem - devido às liberações de bilhões de toneladas de produtos químicos sintéticos no meio ambiente, muitos desses capazes de quebrar a harmonia da natureza.

1997 - GOVERNO - O protocolo de Kyoto fortaleceu as propostas da Convenção das Mudanças Climáticas realizada em 1992, exigindo que os países industrializados cortem suas atuais emissões em pelo menos de 6 a 8 por cento dos níveis de 1990, valendo o período de 2008 a 20012. Mas as controvérsias sobre o protocolo e as negociações das emissões pelos países industrializados deixam obscuro o futuro do protocolo.

1997 - FLORESTAS - As queimadas das florestas do mundo chegam a 5 milhes de hectares, tanto de floresta como de outras terras. Mais florestas foram queimadas em 1997 que em qualquer outro ano da historia.

1998 - CAMADA DE OZÔNIO - O buraco na Camada de Ozônio na Antártica cresceu para 25 milhões de quilômetros quadrados (o registro precedente era de 3 milhões de quilômetros quadrados em 1993).

1999 - GOVERNO - Os maciços protestos da sociedade civil em Seatle ajudaram as negociações do comercio internacional destacando o pouco caso da Organização Mundial do Comércio para com as questões ambientais e sociais.

2000 - TóxICOS - O tratado de Poluentes Orgânicos Persistentes (POPs), pediu o fim do uso de nove substancias, pesticidas altamente tóxico e a limitação de uso de outros substâncias químicas.

2000 - BIODIVERSIDADE - O protocolo de Biosafety (ONU) programa uma aproximação mais criteriosa para o comercio agropecuário mundial, requerendo por parte dos importadores compromissos prévios para enviara os produtos geneticamente modificados. 
2001 - CLIMA - O IPCC divulga um relatório que mostra "evidencias novas e mais fortes sobre o impacto das atividades humanas, no aquecimento global nos últimos 50 anos, $O$ estudo projeta, baseando-se nas taxas atuais, que a temperatura da terra aumentará entre 1,4 e 5.8 graus até 2100.

2001 - CLIMA - O presidente americano W. G Bush, anuncia que não ratificará o protocolo de Kyoto, dizendo que o país não tem recursos para reduzir suas emissões de dióxido de carbono.

2001 - BIOTECNOLOGIA - Ao custo de $\$ 3$ bilhões, a Projeto do Genoma Humano relata que o existem 30.000 genes e não os 100.000 esperados pelos pesquisadores. Isso acendeu uma discussão entre diversas correntes de pensamento sobre a manipulação desses genes, tanto para as plantas como para os animais, incluindo nessa discussão a reengenharia humana.

2001 - SAÚDE - Estudo liga quase 2.000 casos de câncer de tiróide ao acidente da Usina nuclear de Chernobyl, em 1986, o maior número de casos de câncer associado ao mesmo acontecimento.

2001 - GOVERNO - Ministros de 142 países encontram-se em Doha, Qatar, para um ciclo de conversas e negociações para ajustar o comercio no novo século.

2001 - FLORESTAS - A ONU relata que países tropicais perdem mais de 15 milhões de hectares de florestas para a agricultura, madeireiras e outras ameaças.

2001 - BIODIVERSIDADE - Estudo estima que 38 milhões de animais sejam contrabandeados das florestas brasileiras a cada ano para serem vendidos no mercado negro. 
2001 - BIODIVERSIDADE - 116 países votam um tratado internacional para plantas geneticamente modificadas, dando aos fazendeiros o direito de negociar e vender sementes, limitando as patentes desse tipo de plantas.

2001 - BIODIVERSIDADE - Cientistas advertem que milho nativo do México sofreu contaminação em contato com milho transgênico dos EUA.

2001 - ÁGUA - A ONU adverte que os reservas de água do mundo estão diminuindo, conseqüência do desflorestamento que provoca erosão e sedimentação dos rios.

2001 - PESCADOS - O Acordo da ONU para Conservação e Gerenciamento dos Estoques Rotas Migratórias dos peixes, impõe regras para a pesca em águas internacionais.

002 - BIODIVERSIDADE - Estudo diz que a metade das biodiversidades regionais da América do Norte está degradada, répteis, pássaros e espécies anfíbias estão ameaçadas atualmente.

2002 - TóxICOS - Relatório informa que até 80 por cento, dos computadores e eletrônica dos Estados Unidos recolhidos para reciclagem são enviados para a Ásia, onde são ameaças para a população e o meio ambiente.

2002 - CLIMA - Uma plataforma de gelo de aproximadamente 3. 250 quilômetros quadrados desprenderam- do Larsem B da Antártica, por causa do aumento das temperaturas na região.

2002 - ENERGIA - Alemanha fixa objetivo para que pelo menos um quarto de suas necessidades domésticas de eletricidade seja gerada pelos ventos até 2025.

2002 - RECIFES E CORAIS - Estudos mostram que o descoramento da Grande Barreira de recifes da Austrália, é bastante sério em pelo menos 60 por cento dos recifes. 
2002 - DESERTIFICAÇÃo - As escolas em Seul, Coréia do Sul, são fechadas devido a enormes nuvens de poeira vinda do deserto chinês (a uma distância de 1.200 quilômetros), que se alastra rapidamente.

2002 - CLIMA - A União Européia ratifica o protocolo de Kyoto, incentivando os países industrializados a reduzirem as suas emissões de gases efeito estufa aos niveis constantes no documento.

2002 - BIODIVERSIDADE - Estudo mostra que conservação das terras agricultáveis e outros usos da terra, consomem $\$ 250$ bilhões a cada ano.

2002 - GOVERNO - 104 Líderes do mundo e milhares de delegados reúnem-se em Johanesburgo, África do Sul, para a Cúpula Mundial sobre Sustentabilidade e Desenvolvimento, onde delimitaram um plano para reduzir a pobreza e proteger o meio ambiente.

2002 - POLUIÇÃO - A ONU adverte que uma nuvem de fumaça de 3 quilômetros de extensão passou pelo sul da Ásia, modificando a estrutura climática, prejudicando a agricultura e a saúde a população.

2002 - POLUIÇÃO - Derramamento de óleo do navio tanque Prestige carregando 77.000 toneladas de óleo contaminou a costa da Galícia espanhola e causou indignação da população mundial.

2003 - BIOTECNOLOGIA - Relatório informa que a área global de plantações de produtos geneticamente modificadas avança 12 por cento ao ano pelo mundo.

2003 - SAÚDE - Relatório diz que taxa de mortalidade da malária renasce "espantosamente elevada" com mais de 3.000 crianças africanas morrendo a cada dia. 
2003 - DIREITOS HUMANOS - A ONU relata que 30 milhões de mulheres e crianças, em toda a Ásia e Pacífico, são traficadas nos últimos 30 anos. $O$ maior comércio de escravos da história.

2003 - ENERGIA - As portas da represa de Three Gorges Dam são fechadas e o rio Chinês Yangtze enche o reservatório, inundando cidades, terras, e sítios arqueológicos e forçou a realocação de 2 milhões de pessoas.

2003 - PESCA - Relatório de cientistas aponta que a pesca industrial matou 90 por cento das melhores e mais importantes espécies de peixes do mundo.

2003 - ALIMENTAÇÃO - O relatório das Agencias sobre AIDS, apontam o problema de abastecimento de remédios no sul da África, onde 7 milhões de necessitados morreram com a epidemia.

2003 - MINERIRAÇÃO - Quinze das maiores mineradoras e produtoras de metais do mundo prometem não explorar mineração em Sítios de Herança Histórica.

2003 - SAÚDE - Os 192 membros do WHO adotam unanimemente o primeiro tratado de saúde pública para reduzir as mortes relacionadas ao tabagismo.

2003 - FLORESTAS - Relatórios sobre a Amazônia apontam aumento de 40 por cento de desflorestamento em comparação a 2001, e o Brasil registra a segunda maior marca em 15 anos.

2003 - CLIMA - O hemisfério norte da Terra teve um aumento de temperatura média anual desde 1980, maior que os outros 2.000 anos passados.

2003 - CLIMA - Europa adota a primeira lei de negociação de emissões, dando ao carbono valor de mercado na União Européia, a se iniciar em 2005. 
2003 - GOVERNO - A reunião OMC em Cancun, México, entrou em colapso devido às disputas dos subsídios dados a produtos agrícolas por parte dos países industrializados.

2003 - ECOSISTEMAS - O relatório dos UN diz que o número de áreas protegidas no mundo passou de 100.000 , cobrindo uma superfície da terra maior que a Índia e China juntos.

2004 - POLUIÇÃO - A UE emitem primeiro relatório sobre poluição. O relatório contém grande riqueza de dados que representam um marco histórico na utilização desses dados pelas autoridades.

2004 - BIODIVERSIDADE - Estudos reportam que na década passada, a guerra, a caça, a mineração e outras ações humanas acabaram com 70 por cento da população global dos gorilas, sobrando apenas 5.000 pelo mundo.

2004 - CLIMA - Mais de 2.000 pessoas são mortas durante uma chuva torrencial que inundou o Haiti e a República Dominicana. Ambientalistas culpam o desflorestamento do alto dos montes pelos deslizamentos que soterraram colheitas, animais, e populações.

2005 - CLIMA - Furação KATRINA, atinge os Estados Unidos, causando inúmeras mortes e incalculáveis prejuízos materiais [106, 107].

2007 - CLIMA - IPCC divulga o primeiro relatório sobre mudanças climáticas mundiais. No relatório os cientistas apontam que as atividades humanas são as principais causadoras do aquecimento global.

2007 - CLIMA - IPCC divulga o segundo relatório sobre mudanças climáticas mundiais. No relatório os cientistas decorrem sobre as conseqüências do aquecimento, principalmente para demonstrar que suas conseqüências são uma realidade, e caso não se tome medidas imediatas, o futuro os danos terão proporções inúmeras vezes maior. 
2007 - CLIMA - IPCC divulga o terceiro relatório sobre mudanças climáticas mundiais. No conteúdo deste relatório estão medidas que têm urgência em serem adotadas, tais como o investimento em fontes de produção de energia mais limpas, utilização de veículos mais eficientes no quesito consumo de combustível e emissão de poluentes, diversificação da matriz energética, diminuição do desflorestamento, sobre tudo na Amazônia, entre outras medidas para diminuir o impacto das atividades antropogênicas no clima do planeta.

2007 - CLIMA - IPCC divulga o quarto relatório sobre mudanças climáticas mundiais. [108]

2007 - GOVERNO- O governo norte americano admite a necessidade de se reduzir as emissões de gases efeito estufa, entretanto não se compromete com o Protocolo de Quioto, nem com qualquer tratado internacional.

2007 - GOVERNO - ONU anuncia através do Programa das Nações Unidas para o Meio Ambiente (PNUMA), que a meta de plantar um bilhão de árvores no ano de 2007 foi cumprida.[109] 


\section{ANEXO B - Índices utilizados no Trabalho}

\section{Definição de Î́ndice}

Os índices e os indicadores são formas de descrever e quantificar fenômenos de diversas naturezas.

De acordo com Spanger 2003:

"existe uma estreita relação processual entre indicadores e índices. Enquanto indicadores se destinam a descrição de aspectos parciais de um fenômeno, índices visam sintetizar a descrição do mesmo, agregando vários destes indicadores, para que seja possivel obter um quadro mais próximo da realidade" [38].

A definição de índice segundo o dicionário é "valor obtido através de uma série de observações é utilizado como indicador de freqüência ou nivel de uma realidade quantificável' [49].

Ao longo dos últimos 40 anos, vários indicadores e índices foram criados com a intenção de explicar a relação do homem com a economia, sociedade e meio ambiente. Devido à complexidade da elaboração de um índice, há a possibilidade de manipulação de resultados. Por esse motivo os índices devem ser apresentados com um relatório onde constem a metodologia e dados utilizados, com isso possibilitando uma maior confiabilidade [38].

Os índices selecionados para este trabalho foram elaborados por entidades de grande relevância mundial.

É oportuna a observação de Spanger [38], com relação a índices que necessitam de extensas explicações, pois isso afeta seu valor de comunicação. Esse pode ser o motivo pelo qual os índices sócio-ambientais sejam pouco conhecidos do publico em geral. 


\section{B1 - Pegada Ecológica}

A pegada ecológica ("FootPrint") é o principal índice analisado no presente trabalho por ser um índice que esta ligado diretamente ao consumo em geral e seus rejeitos, levando em conta não apenas o impacto da produção como também o impacto ambiental.

Seus criadores, Mathis Wackernagel e Willian Rees [39], ambos os professores e pesquisadores do 'UBC's Healthy and Sustainable Comununities Task Force", tinham a intenção de responder a questão: quanto o homem realmente esta usando de natureza. Para responder a esta questão criou-se um índice, nomeado de Ecological Footprint, traduzido para o português como

\section{Pegada Ecológica}

Como já dito anteriormente, a Pegada Ecológica á a área total necessária para produzir alimentos, energia e insumos e também eliminar a poluição de cada ser humano de maneira sustentável e a cota da energia é a maior e a que cresce mais rapidamente também. O ciclo da energia é, dentre todas as demais atividades humanas, a que mais contribui com os grandes problemas ambientais globais (efeito estufa, chuva ácida e mudanças climáticas) devidos, principalmente, as emissões de $\mathrm{CO}_{2}$. Essas emissões estão num crescente ao longo das últimas décadas como nunca na história.

As emissões de $\mathrm{CO}_{2}$ estão crescendo e, segundo todas as previsões, isso vai continuar pelo menos nas próximas décadas. As concentrações de $\mathrm{CO}_{2}$ estão, segundo a maioria dos cientistas que estudam esses fenômenos, diretamente relacionadas ao aquecimento global e mudanças climáticas.

Dentre outras conseqüências das alterações ambientais que estão ocorrendo no mundo, a escassez de água é o que criará provavelmente mais transtornos no mundo, num futuro relativamente próximo. Esse é um dos temas mais importantes a ser abordado em futuras pesquisas [12].

De acordo com esse índice o máximo que o ser humano poderia utilizar para sua sobrevivência seria de 1,8 hectares por habitante, atualmente o ser humano precisa de 2,85 hectares para sua sobrevivência (média mundial), a diferença é a quantidade de natureza que está sendo consumida. 


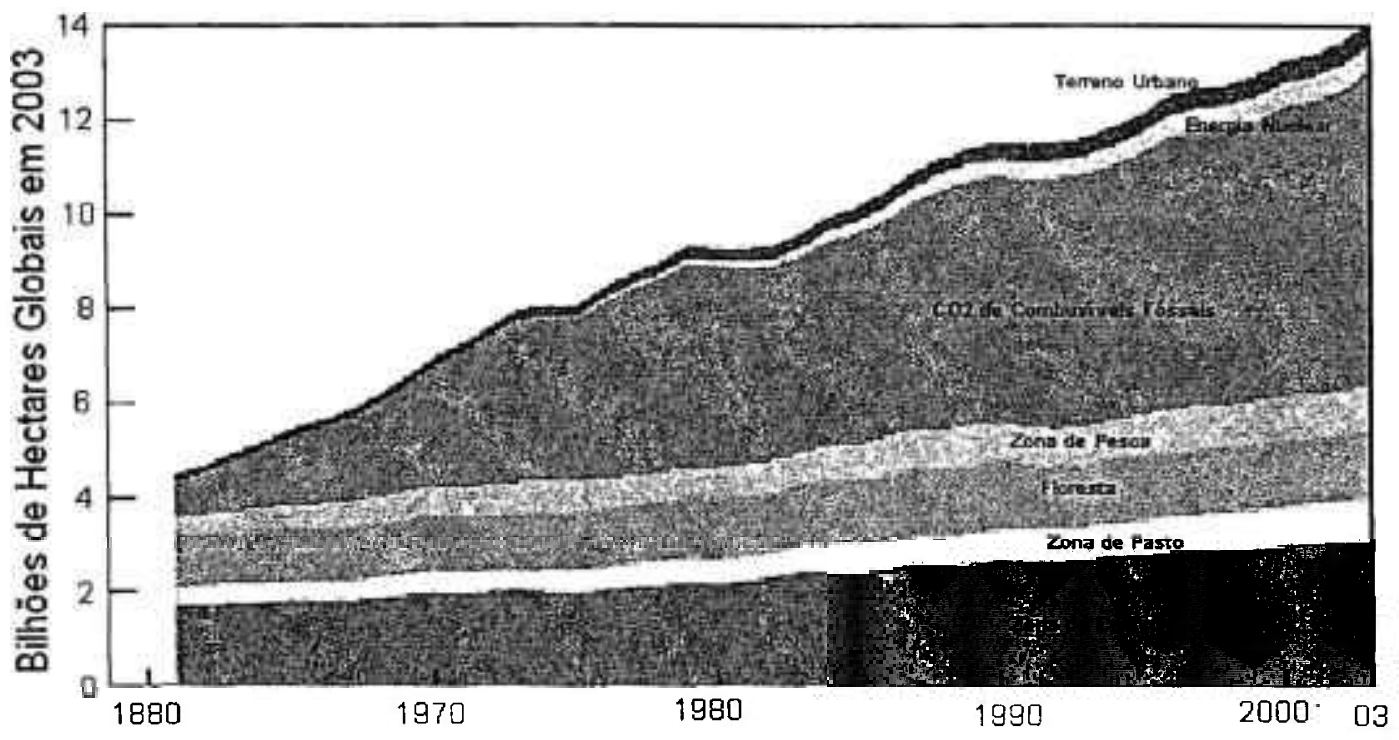

FIGURA 24 - Evolução da "Pegada Ecológica" por componente, 1961-2003 [12].

O índice Pegada Ecológica (PE) está diretamente ligado aos padrões de consumo das nações, pois quanto mais se consome maior é o índice.

Observa-se através do gráfico acima a participação de cada componente na formação do índice, confirmando a grande participação do item energia. Este, por sua vez, é o grande responsável pela geração de $\mathrm{CO}_{2}$.

Percebe-se que a tendência é de crescimento, como a observação feita pelo mesmo relatório.

A PE Global quase que quadruplicou entre 1961 2003, aumentando mais rapidamente que a população, que quase duplicou durante o mesmo período. Em outras palavras isso significava que, em média, cada ser humano está consumindo cada vez mais [12].

$\mathrm{Na}$ realidade a análise mais detalhada dos dados constata que os niveis de consumo são bem desiguais entre os países (alguns países consomem muito e outros pouco).

Os níveis de renda também influenciam o índice pegada ecológica, pois quanto maior a renda maior a capacidade de compra de produtos e serviços, aumentando assim o índice.

De acordo com o gráfico 25 [12] alguns países têm grandes débitos e, nestes casos, é urgente a necessidade de aumentar o consumo de produtos ambientalmente sustentáveis (do ponto de vista do PE), diminuindo assim o consumo de produtos não sustentáveis, essa afirmação leva ao raciocínio de que 
os paises com saldo positivo de PE poderiam consumir sem grandes preocupações, porém isso não é verdade, pois no cômputo gera, na população mundial o PE é negativo e mesmo os países com saldo positivo, em sua maioria, possuem esse saldo por falta de consumo e não por consumo ambientalmente correto.

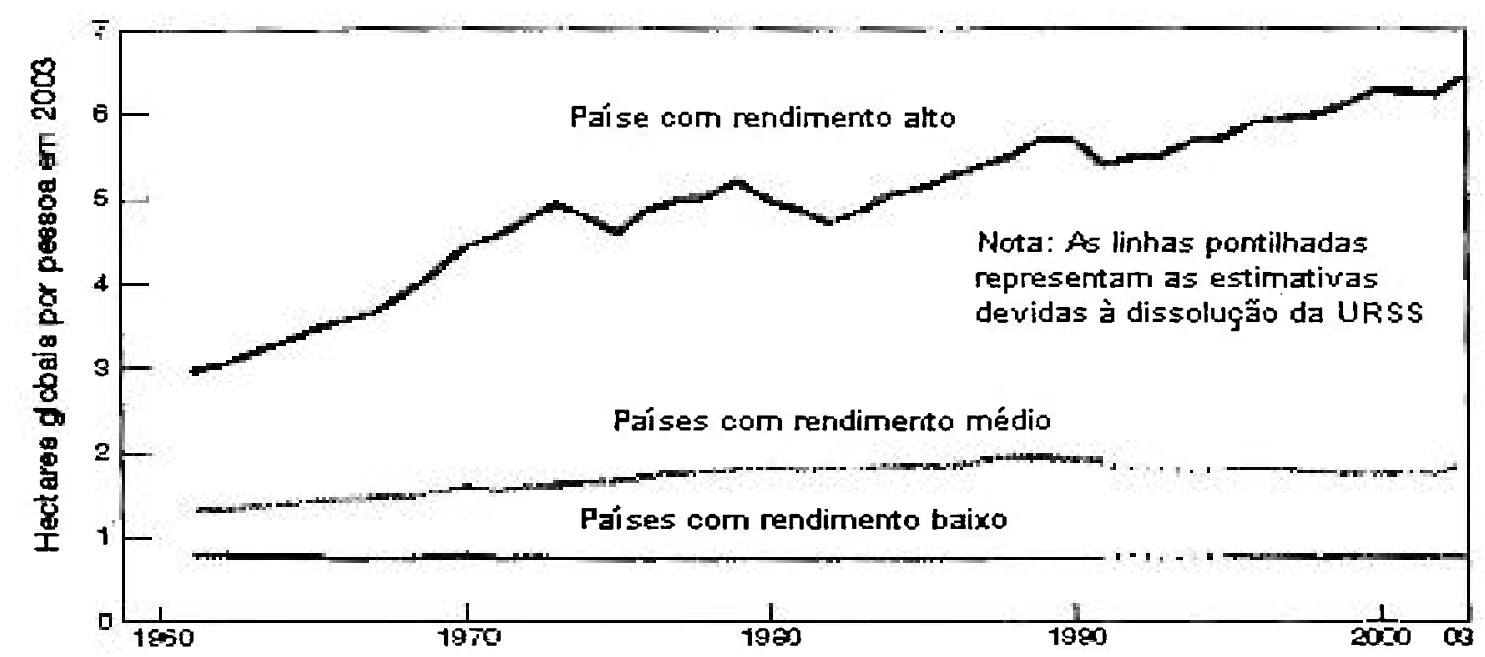

FIGURA 25 - Evolução da "Pegada Ecológica" por grupo de rendimento nacional por pessoa, $1961-2003$ [12].

Apenas para ilustrar a gravidade do que demonstra o indice e a sua importância, se a população da China alcançar o padrão de consumo, per capita, do americano médio, ou melhor, a "pegada ecológica" dos americanos, seriam necessários quatro planetas para suprir tal demanda [12]. 


\section{B2 - Índice de Desenvolvimento Humano - IDH}

O IDH apresenta uma medida conjunta de três dimensões do desenvolvimento humano: viver uma vida longa e saudável (medida pela esperança de vida), educação (medido pela alfabetização de adultos e pelas matrículas nos níveis primário, secundário e superior) e o "padrão de vida" (medido pelo rendimento em paridade do poder de compra da moeda local, PPC) [46].

A publicação deste índice, feito pela ONU, é anual, e procura observar as alterações ocorridas de um ano para o outro. $O$ índice de desenvolvimento humano (IDH) não abrange todos os lados do desenvolvimento humano, porém é um forte indicador da situação em que se encontram indivíduos de uma determinada sociedade.

A renda per capita de um país é um forte componente do IDH, na medida em que essa renda favorece os outros componentes indiretamente (saúde e educação), porém existem paises que conseguem maior IDH com menores niveis de renda, como no caso do Chile e do Bahrein, pois ambos têm PIBs per capita idênticos, porém seus IDH são bastante diferentes como na fig. 26 .

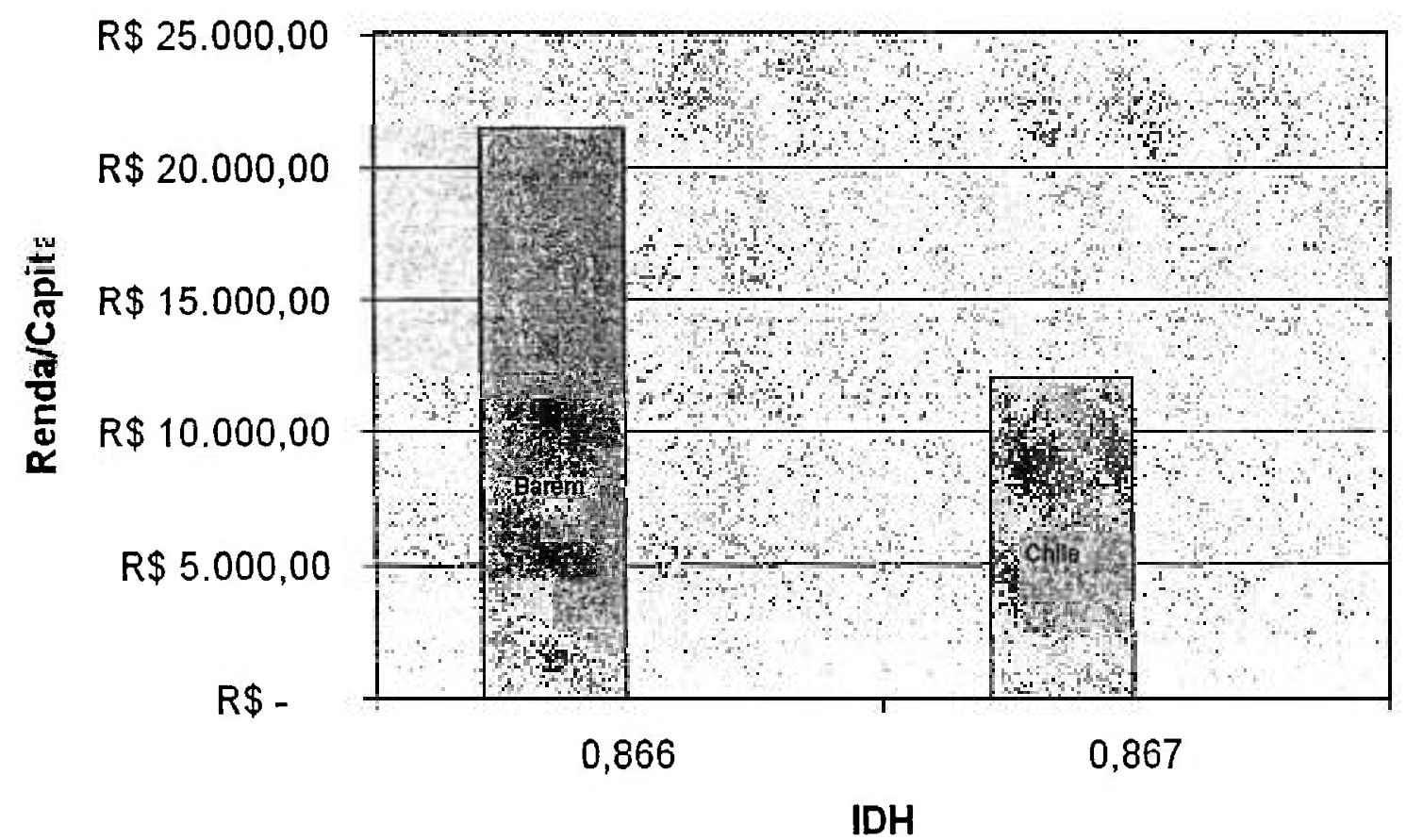

FIGURA 26 - Comparação Renda/capita e IDH entre Chile e Bahrein Fonte-PNUD [46]. 


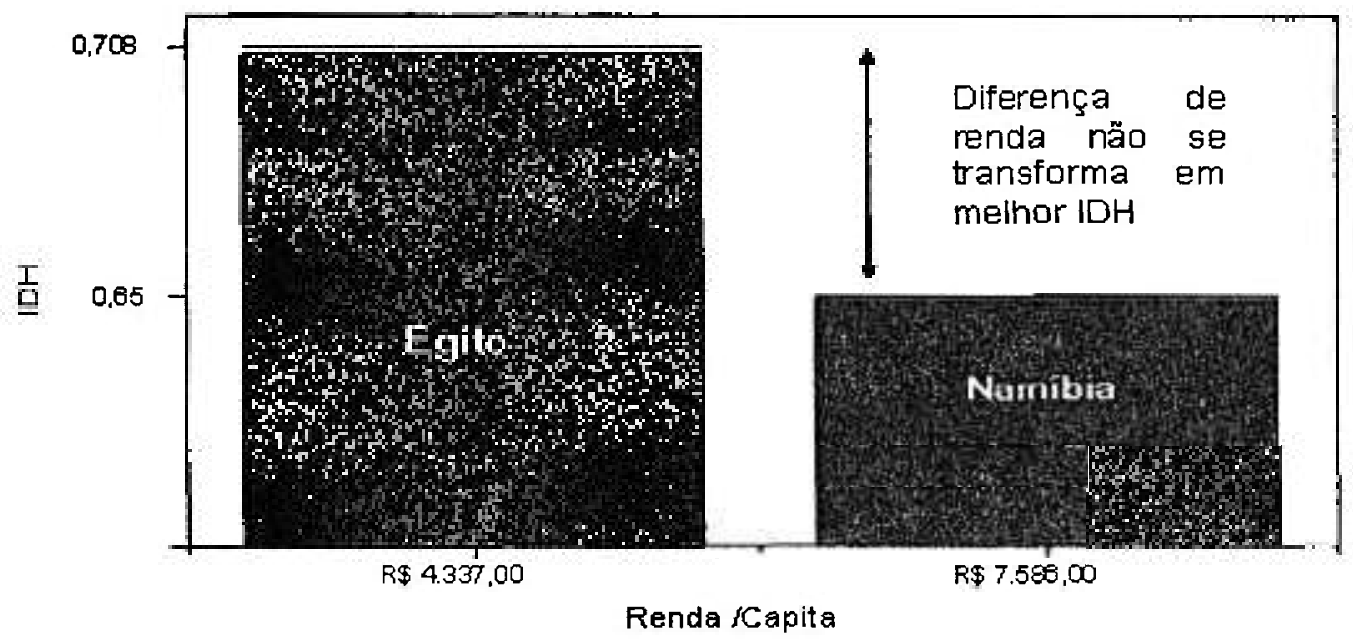

FIGURA 27 - Comparação entre Egito e Namíbia, renda e IDH Fonte: 46.

A figura acima mostra que alguns países são mais eficientes nos usos de seus recursos quando se trata de valorizar a qualidade de vida de sua população.

A classificação é feita em três níveis, elevado, médio e baixo, onde os índices variam da forma da tabela abaixo.

TABELA 6 - Classificação do IDH

\begin{tabular}{c|c}
\hline Ideal & 1,00 \\
\hline Elevado & Igual ou maior que 0,80 \\
\hline Médio & Entre 0,50 e 0,79 \\
\hline Baixo & Abaixo de 0,49 \\
\hline
\end{tabular}

$\mathrm{Na}$ classificação dos países com IDH igual ou superior a 0,8 , possuem renda per capta acima de $\$ 7.000,00$, porém nem todos os países com renda superior têm IDH nesse nível. 


\section{B3 - Índice de Felicidade do Planeta (The Happy Planet Index)- HPI}

A fundação New Economic [45], definiu o HPI pela seguinte fórmula:

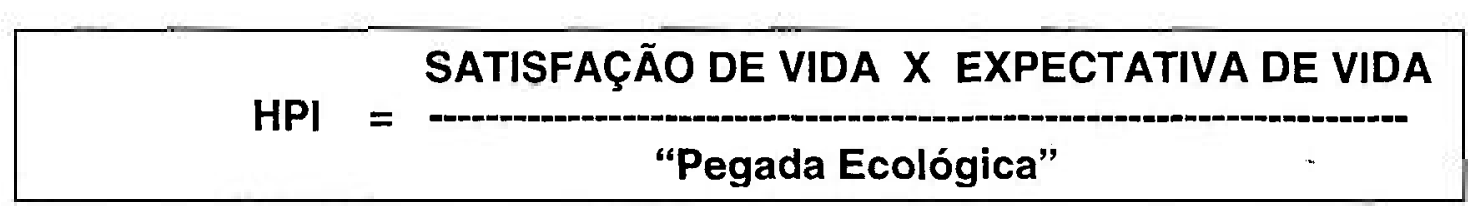

Ou ainda "uma média de anos de uma vida feliz produzida por uma dada sociedade, nação ou grupo de nações, por unidade de recursos consumido do planeta".

Onde:

-Satisfação de Vida - medida subjetiva que é determinada através de pesquisas em ciências sociais e psicológicas para entender fatores que influenciam o bem estar e a correlação da confiabilidade, predita em indicadores objetivos, associados ao bem estar (questionários considerando vários aspectos do sentimento humano) humano.

Satisfação de vida é medida através de questionários aplicáveis a população. Apesar de ser uma medida bastante subjetiva é a que melhor retrata a satisfação do indivíduo em seu meio,

- Expectativa de Vida - medida objetiva de relativa facilidade de mensuração e

-"Peqada Ecológica" - como definido no item B1. 


\section{B4 - Índice de Sustentabilidade Ambiental}

O Índice de Sustentabilidade Ambiental -ISA- (Environmental Sustainability Índex - ESI [45] foi apresentado em 2002 no Fórum Econômico Mundial por pesquisadores das universidades americanas Yale e Columbia. $O$ ISA tem como objetivo comparar a capacidade dos vários países, no que diz respeito à proteção do seu meio ambiente natural, não só atualmente, mas também com as ações necessárias para que a melhoria aconteça também no futuro. A cada ano, o ISA sofre algumas alterações sempre com o objetivo de refletir melhor $O$ aspecto que envolve a construção de um desenvolvimento baseado na qualidade de vida do homem e do meio ambiente [Columbia University e Yale University [45].

O ISA foi criado com base na integração de 76 variáveis em 21 indicadores de sustentabilidade ambiental que resultam num índice que varia de 0 a 100, sendo 100 a melhor avaliação. O ISA foi desenvolvido com o propósito de ser um instrumento de auxílio dos tomadores de decisão no que tange à questão ambiental da região ou nação. O ISA também foi pensado como uma complementação ao PIB e ao IDH na avaliação do progresso de um país, na medida em que possibilita uma análise segundo uma ótica ambiental.

Os países de industrialização mais avançada têm suas economias associadas a fluxos energéticos e de materiais de tal monta, que causam, inexoravelmente, impactos ao ambiente natural e que são captados pelos componentes do ISA. As atividades econômicas intensivas em energia e em materiais desses países, mesmo com elevados graus de eficiência (baixa Intensidade Energética), afetam de alguma forma a sustentabilidade de suas economias, pois a manutenção desses fluxos influi diretamente nos recursos naturais, que são finitos, e na capacidade de absorção dos resíduos.

Os piores índices estão entre as nações em desenvolvimento e nações pobres da África. Esta constatação é porque muitas destas nações ainda precisam prover suas populações de condições mínimas de sobrevivência. O Índice de Sustentabilidade Ambiental evidencia a já conhecida, porém não provada, relação entre renda e preservação ambiental. Outra evidência demonstrada é que o cuidado com o meio ambiente e a manutenção das 
potencialidades do desenvolvimento em bases sustentáveis é um desafio tanto para os países ricos quanto para os países pobres.

É importante destacar que, em função das especificidades locais, as melhores práticas nem sempre podem ser retratadas em outros lugares. $\mathrm{Na}$ medida em que existem fatores ligados às atividades econômicas, à assistência social e às condições do meio ambiente do presente, as combinações entre elas e o estado de cada fator resultam em realidades distintas.

A heterogeneidade do ISA é bastante grande, bem maior que a do IDH por exemplo. São raros os casos onde os componentes do IDH estão nos extremos, ou seja, um país com baixa renda e alta expectativa de vida. No entanto, o Índice de Sustentabilidade Ambiental, é constituído por componentes tão díspares quanto à qualidade dos sistemas ambientais e a capacidade sócioinstitucional. Ou seja, um país pode ter áreas preservadas, sem atividade econômica, o que pode favorecer a qualidade do ar e a biodiversidade, por exemplo, e ao mesmo tempo apresentar baixos índices de ciência e tecnologia e governança ambiental.

A figura abaixo mostra este índice através do mundo (tons mais escuros equivalem aos melhores valores do ISA.

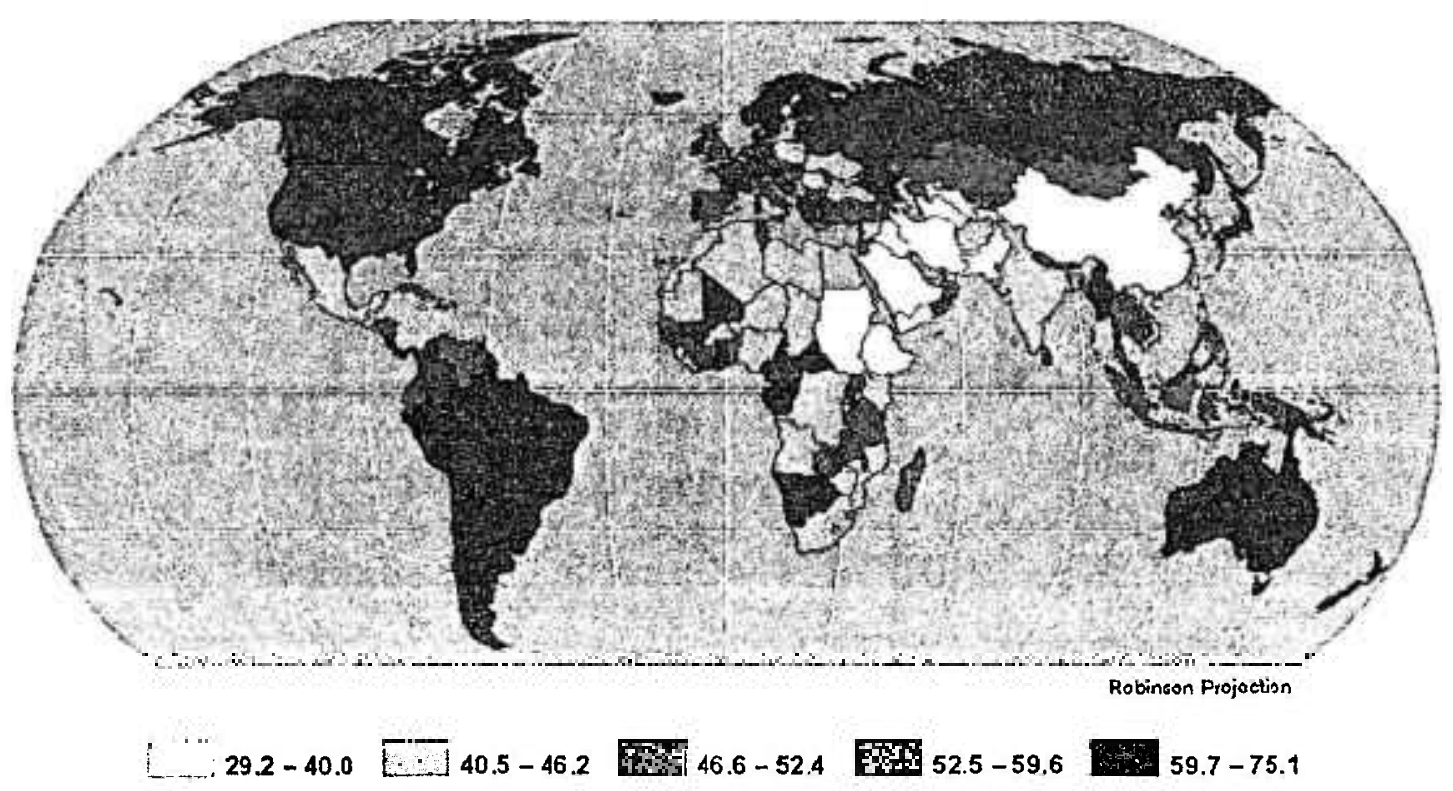

FIGURA 28 - ISA através do mundo (tons mais escuros equivalem aos melhores valores do ISA) [45]. 


\section{B5 - Índice Gini}

É baseado na curva de Lorenz que é um diagrama que representa esquematicamente a distorção da distribuição de renda numa determinada economia. Se a curva é uma reta a 45 graus, isso representa a equidade perfeita. Quanto mais a curva se desvia da diagonal, maior é o grau de desigualdade da economia, ou seja, o indice Gine aproxima-se da unidade. Essa é a situação hipotética onde uma pessoa retém toda a renda de uma população. Quando a curva tende à diagonal, é a situação hipotética, onde há uma distribuição equânime da renda e o IG aproxima-se de zero. O gráfico a seguir representa a curva de Lorenz mundial, situação em que $61 \%$ da população retém apenas 5\% da renda, outros $23 \%$ da população retém $13 \%$ da renda e a última faixa, a dos mais ricos ( $17 \%$ da população) que retém $82 \%$ da renda

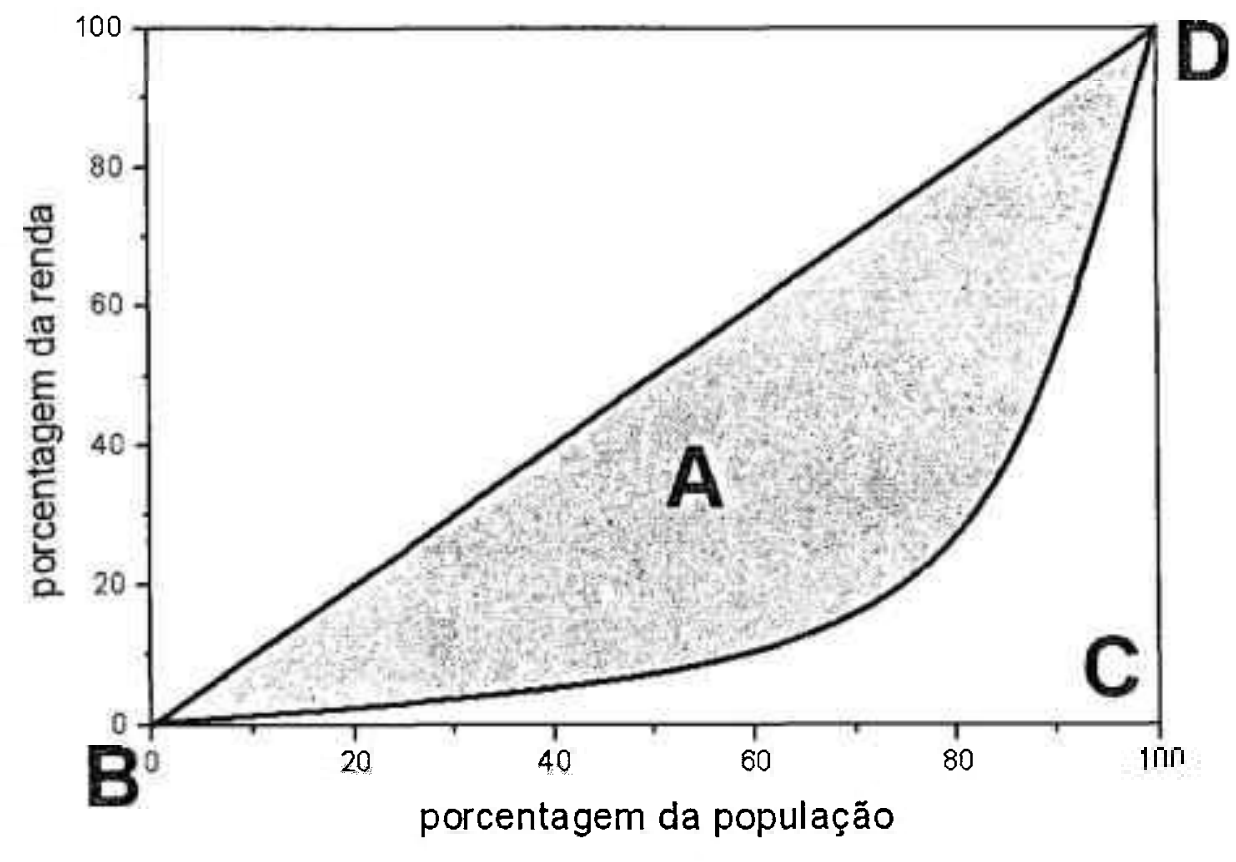

FIGURA 29 - Curva de Lorenz mundial.

O índice Gini (IG) é calculado como:

$$
\text { IG = área A / área do triảngulo } \mathrm{BCD}
$$




\section{ANEXO C - Externalidades}

$\mathrm{Na}$ atualidade os preços dos produtos refletem apenas os seus custos de produção e comercialização, não considerando os impactos que a fabricação e utilização desses produtos possam causar ao meio ambiente e/ou a sociedade. Esses possíveis impactos são as chamadas externalidades.

Os valores dos produtos obedecem a uma lei de oferta e procura. Com isso a composição dos preços dos mesmos se dá da forma descrita na FIG.30.

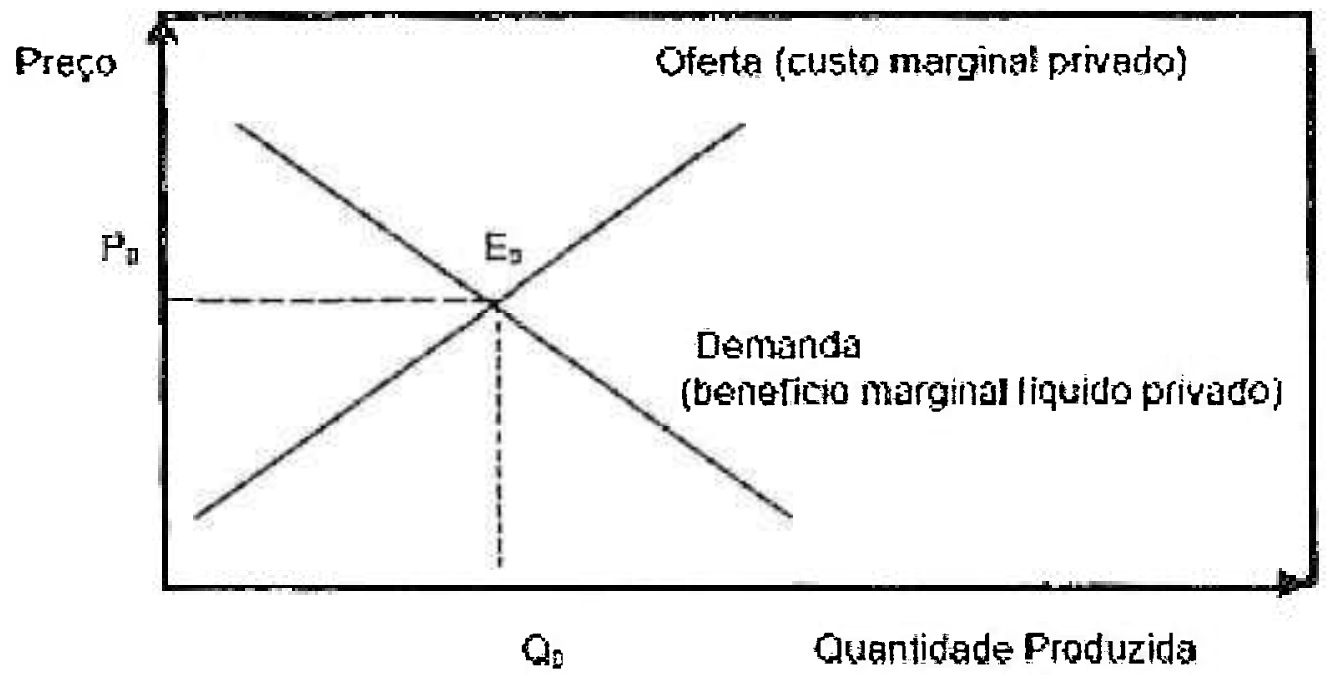

FIGURA 30 - Equilibrio de mercado na ausência de externalidades [33].

Onde:

EO = Equilíbrio de mercado,

$\mathrm{PO}=$ Preço no equilíbrio de mercado e

Q0 $=$ Quantidade no equilíbrio de mercado.

A FIG.30 mostra um mercado em um estado perfeito. Nessa condição quanto menor o preço, maior a demanda (quantidade de produtos vendidos). Este caso serve para verificar como se forma o custo de um produto. O chamado custo marginal é a variação no custo total de produção advinda da variação em uma unidade da quantidade produzida. Graficamente, a curva que representa a evolução do custo marginal é uma parábola concava, cujo ponto mínimo se 
encontra o número de bens que devem ser produzidos para que os custos sejam mínimos. Porém sem considerar possíveis custos sociais ou ambientais.

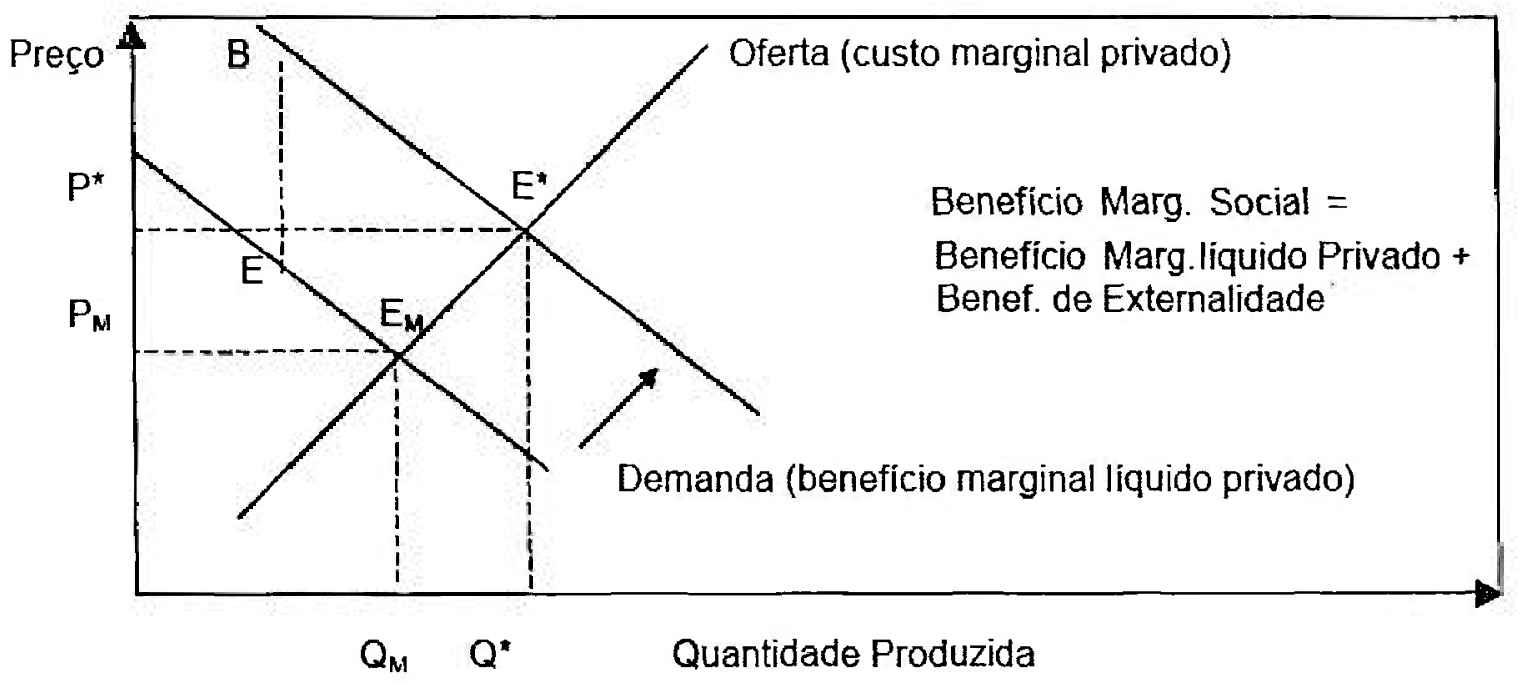

FIGURA 31 - Equilíbrio de mercado na presença de externalidades positivas [33].

Onde:

$E^{*}=$ Equilíbrio na presença de externalidades,

$E_{M}=$ Equilíbrio de mercado,

$\mathrm{P}^{\star}=$ Preço de equilíbrio na presença de externalidades,

$P_{M}=$ Preço no equilíbrio de mercado,

$Q^{*}=$ Quantidade produzida com cômputo dos benefícios externos e

$Q_{M}=$ Quantidade no equilibrio de mercado.

No caso acima, as externalidades que foram incorporadas são positivas. Isso faz com que o preço pago pelo produto seja menor que seu real benefício e, neste caso, o aumento de preço e de demanda são compatíveis e até mesmo desejáveis. Um bom exemplo disso é a educação - quanto mais se investe em educação, maiores são os benefícios sociais e não se causa danos ao meio ambiente.

Outro produto que se pode citar é o álcool combustível, pois em seu ciclo de produção elimina $\mathrm{CO}_{2}$ e ainda evita a emissões por parte do consumo de produtos derivados dos combustíveis fósseis. 


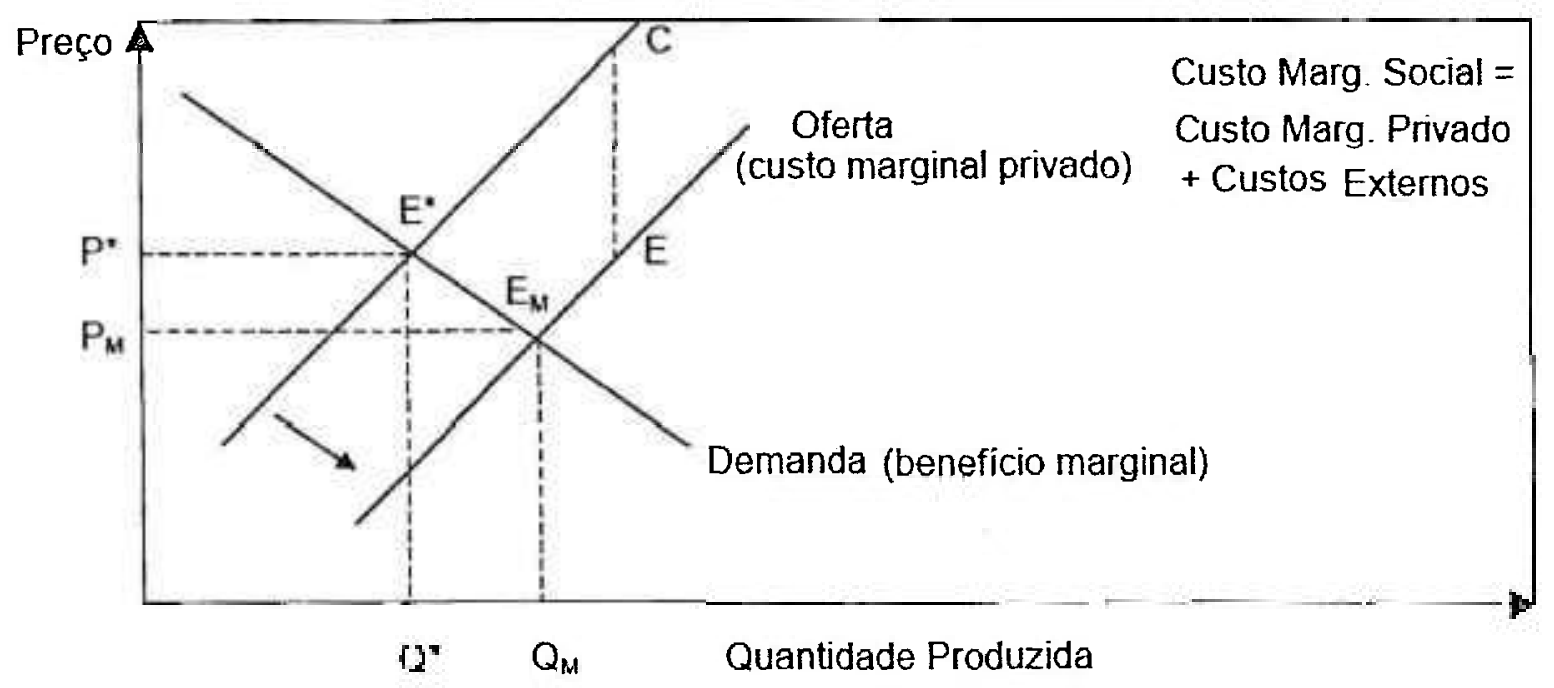

FIGURA 32 - Equilíbrio de mercado na presença de externalidades negativas [33].

$\mathrm{Na}$ FIG.32 tem-se a situação onde o custo das externalidades é negativo. Nesse caso deve-se observar que o custo do produto se desloca a um patamar maior. O produto fica mais caro e diminui sua demanda, o que seria desejável. Isso por agregar ao seu preço os custos das externalidades. Esta situação é verificada nos pontos $Q^{*} e E^{*}$. A diferença entre os preços com e sem externalidades equivale aos custos para recuperar os prejuízos causados pelo bem.

Um exemplo disso é a indústria de petróleo. Caso esta incorporasse os valores necessários para capturar o $\mathrm{CO}_{2}$ que seus produtos emitem, o preço seria maior o que, em teoria, diminuiria a demanda. $O$ impacto ambiental também seria menor, pois as indústrias teriam a obrigação de eliminar todo $\circ \mathrm{CO}_{2}$ que fosse emitido [33].

No caso dos automóveis híbridos, que tem seu preço maior que os comuns, com a incorporação das externalidades, provavelmente seu custo ficaria mais atrativo. É claro que tudo isso necessita de muitos estudos e regulamentações. Mas não deixa de ser uma boa forma de se incentivar seu comercio. 


\section{REFERÊNCIAS BIBLIOGRÁFICAS}

1. Relatório da Conferência das Nações Unidas Sobre Meio Ambiente Humano (Stockholm 1972) Disponível em:

$<$ http://www.unep.org/Documents/Default.asp?DocumentlD=97>. Acesso em: setembro 2004.

2. Programa das Nações Unidas Para o Desenvolvimento do Meio Ambiente Disponivel em:

$<$ http://www. unep.org/Documents.multilingual/Default.asp?DocumentID=97\&A riclelD=1493\&|=en>. Acesso em: setembro 2004.

3. Cúpula de Johanesburgo (Johann esburgo 2002) Disponível em: $<$ http://www.johnnesburgsummit.org> . Acesso em: agosto 2004.

4. Conferência das Nações Unidas Sobre Meio Ambiente e Desenvolvimento (UNCED), (Rio de Janeiro 1992) Disponível em:

$<$ http://www.un.org/geninfo/bp/enviro.html/>. Acesso em: Agosto 2004.

5. Diversos Eventos Promovidos pela ONU (Organização das Nações Unidas) e Também Futuros - Disponivel em:

$<$ http://www.un.org/spanish/conferences/eventos.shtml>. Acesso em: junho de 2004.

6. Programa das Nações Unidas para o Meio Ambiente (PNUMA) - Disponível em <http://www.rolac.unep.mx/perfil/esp/index.htm>. Acesso em: Agosto 2004.

7. Divulgação do Fórum Social Mundial (Porto Alegre) - Disponível em: $<$ http://www.planetaportoalegre.net/publique>. Acesso em: Agosto 2004.

8. Programa das Nações Unidas para o Desenvolvimento - Disponível em: $<$ http://www.undp.org >. Acesso em: Maio 2004.

9. Fórum de Notícias para Desenvolvimento e Meio Ambiente (IPS.. Inter Press Service) - Disponível em: <http://ips.org>. Acesso em: Setembro 2004.

10. GREENPEACE - Organização Não Governamental -Disponível em: <http://www.greenpeace.org/international_en>. Acesso: em Maio 2004

11. Agencia de Proteção Ambiental Americana (EPA)-Disponível em: $<$ http://www.epa.gov>. Acesso em: Maio 2004. 
$<$ http://assets.panda.org/downloads/lpr2006portuguese.pdf>. Acesso em: novembro 2007.

13. ORGANIZAÇÃO DAS NAÇÕES UNIDAS, Protocolo de Quioto à convenção - quadro das nações unidas sobre mudança do clima, ONUBRASIL. Disponivel em: : <http://www.onu-brasil.org.br/doc_quioto.php $>$ Acessado em: novembro 2005.

14. Folha de São Paulo, Fósseis dominam energia até 2030, prevê relatório, Caderno Ciências, p. A 20. São Paulo, 8 de novembro de 2007.

15. LANDS, David J.; Prometeu desacorrentado - Transformação tecnológica e desenvolvimento industrial da Europa ocidental, de 1750 até os dias de hoje. Tradução Marisa Motta, $2^{\circ}$ edição, Campos Rio de Janeiro RJ: 2005.

16. CANHEDO, L. B., A Revolução Industrial, $4^{\circ}$ ed. - Campinas, Unicamp. 1987.

17. VEIGA, J. E. DA, AS ondas longas do capitalismo industrial, Revista da Sociedade Brasileira de Economia Política, n. 3, pp. 59-79, São Paulo 1998.

18. COSTA, A. B., O desenvolvimento econômico na visão de Joseph Schumpeter, Cadernos IHU Idéias Ano 4- $N^{\circ} 47-2006$, Universidade do Vale do Rio dos Sinos Instituto "Humanitas Unisinos", Disponivel em: $<$ www.unisinos.br/ihu $>$. Acessado em: maio 2007.

19. COTRIM, Gilberto, História global: Brasil e geral, 7 a edição, 3a impressão, São Paulo, Saraiva, 2002, pág. 270.

20. AREAM; A economia do Hidrogênio. Sítio eletrônico da Agência Regional da Energia da Região Autônoma da Madeira, Portugal. Disponível em: $<$ www.aream.pt/download/brochras $>$. Acessado em: junho 2005.

21. MATTOS, L. V.; As razões do laissez-faire: uma análise do ataque ao mercantilismo e da defesa da liberdade econômica na Riqueza das Nações, Revista de Economia Política, vol. 27, nº 1 (105), pp. 108-129, janeiro-março/2007. Disponível em:

$<$ http://www.scielo.br/scielo.php?pid=S0101: $31572007000100006 \&$ script=sci pdf\&t lng=pt $>$. Acessado em: abril 2005.

22. PARANHOS, K. R., Formação Operária: Arte de Ligar a Política e Cultura; Educ. Soc., Campinas, vol. 26, n.9, p.266-288, 2005. Disponível em: $<$ http://www.cedes.unicampi.br $>$. Acessado em: outubro 2006.

23. AUGUSTO, Acácio, A luta dos anarquistas contra o sistema penal e a emergência da ação global de associações que compõem a Cruz Negra Anarquista (CNA), Revista Urutágua, $n^{\circ} 6,2004$, disponivel em $<$ http://www.urutagua.uem.br//006/06auqusto.htm>. Acessado em: maio 2005. 
24. Philip, A., História dos fatos econômicos e sociais de $\mathbf{1 8 8 0}$ aos nossos dias, Moraes, Lisboa 1965.

25. LEVY, M. S. F.; O papel da migração internacional na evolução da população brasileira (1872 a 1972). Rev. Saúde Pública, June 1974, vol.8 suppl, p.49-90.

26. Caneco, .; O século XIX - História Geral das Civilizações, 169, pg. 133 Apud. 1987, pg. 66.

27. BARBIERI, C.; Comentário sobre o livro "As 100 maiores invenções", Tom Philbin. Revista Isto é Dinheiro, Editora Três, 2006, disponível em: $<$ http://www.terra.com.br/istoedinheiro/461/ecommerce/as 100 maiores inve ncoes.htm>. Acessado 04/2007.

28. HOLDREN, J. P., Energy in transition, Scientific American, vol. 263 n. 3, 1990.

29. MONTEIRO, C. A., Mobilidade Sustentável em Portugal. Uma Quimera? Uma análise conceptual e empírica da gestão da mobilidade urbana 'sustentável' ao nível dos conselhos portugueses. 2004/2005.

Dissertação (Mestrado) - Faculdade de Engenharia da Universidade do Porto, Porto.

30. Agencia Internacional de Energia, World Energy Outlook, 2004, Paris, France 2004.

31. FADUL, A.; Indústria cultural e comunicação de massa. Série Idéias n. 17. São Paulo: FDE, 1994. p. 53- 59.

32. SHETH, J. N.; MITTAL, B.; NEWMANN, I. B.; Comportamento do cliente: indo além do comportamento do consumidor. São Paulo: Atlas, 2001.

33. MARTINS, A. R. P.; Desnvolvimento sustentável: uma análise das limitações do índice de desenvolvimento humano para refletir a sustentabilidade ambiental. Niterói 2006. Dissertação de mestrado em Engenharia de Produção da Universidade Federal Fluminense, área de concentração Estratégia, Gestão e Finanças empresariais. Disponivel em: $<$ http://www.bdtd.ndc.uff.br/tde arquivos/29/TDE-2006-08-24T111057Z343/PublicolAna\%20Raquel\%20Paiva\%20Martins.pdf>. Acessado em: junho 2007.

34. KOTLER, P.; KELLER, K. L.; Administração de marketing. A bíblia do marketing. $12^{a}$ ed. São Paulo: Prentice Hall, 2006.

35. CHIAVENATO, I.; Introdução a Administração Geral, São Paulo, Campus, 2005. 
36. Worldwatch Institute (WWI), O Estado do Mundo 2004: Estado do consumo e o consumo Sustentável, 2004. Disponível em:

<http://www.worldwatch.org/topics/consumption>. Acesso em: Maio 2005.

37. COUTINHO, M.; LUCATELLI, M.; Produção científica em nutrição e percepçao pública da fome e alimentação no brasil. Publicado na revista Saúde Pública, v. 40 n. Especial 2006, São Paulo disponível em: $<$ http://www.scielosp.org/scielo.php?script=sci_arttext\&pid=S0034$89102006000400013 \& \operatorname{lng}=\& n r m=i s o \& t \operatorname{lng}=>$. Acessado em junho 2007.

38. SPANGER, U.; Representação da Desigualdade de Fenômenos Ecológicos em Índice de Bem Estar, Uma Proposta Metodológica, 2006. Teses de (Doutorado) - Universidade Federal do Paraná, Curitiba, 2006

39. INSTITUTO MILENIUN, A ecomomia solidária. Publicado no sitio eletrônico em 26 de junho de 2006. Disponível em:

$<$ http://www.institutomillenium.org/index3.php?on=artigo\&in=assunto\&artigo i d=269 >. Acessado em: outubro 2006.

40. Ress, W. E; Wackernagel, M.; Our Ecological Footprint: reducing Human Impact on the Earth - Canada, New Society publishers, 1996.

41. PNUMA - Programa das Nações Unidas para o Meio - Brasil - Disponível em: <www.onu-brasil.org.br/agencias pnuma.php>. Acessado em: junho 2004.

42. BRENA, N, A.; A chuva ácida e os seus efeitos sobre as florestas. Nilson Antonio Brena - São Paulo, 2002.

43. Portal Eletrônico de Várias Entidades que Tratam do Aquecimento Global (GLOBAL WARMING: Early Warning Signs) - Disponível em: <http://www.climatehotmap.org>. Acesso em: maio 2004.

44. Agência para Sistemas de Qualidade (BQS) - Disponível em $<$ http://bqs.usgs.gov/acidrain>. Acesso em Maio 2004.

45. TASCHETTO, A. S.; O impacto dos gases estufa nas varaiáveis e superfíce ar-mar através de um nodelo acoplado de circulação geral. USP 2000. dissertação de mestrado. Unidade Instituto Oceanográfico (IO) Área de concentração Oceanografia Física, USP São Paulo. Pg. 2. Disponível em: <http://www.teses.usp.br/teses/disponiveis/21/21132/tdetascheto $>$. Acessado em: setembro de 2006.

46. Yale \& Columbia University, Environmental Sustainability Index - 2002Disponivel em <http://www.ciesin.columbia.edu/indicators/ESl $>$ : Acessado Maio/2004.

47. Nações Unidas - Programa das Nações Unidas para o Desenvolvimento, Relatório do desenvolvimento humano 2006, p. 354, disponível em: $<$ http://www.pnud.org.br/rdh/>, acessado em 28/12/2006. 
48. Mai, L. A.; Carneiro, A., C. Some Relations Involving Enviromenment, Social and Energetic Indexes. In: BIENIAL INTERNATIONAL WORKSOP DA UNICAMP, 4, 2004, Campinas, 2004

49. FERREIRA, A. B. de H. Dicionário Aurélio Básico da Língua Portuguesa. Rio de Janeiro, Nova Fronteira, 1995.

50. SANTOS, L. C. DOS, A questão dos resíduos sólidos urbanos: uma abrordagem socioambiental com ênfase no minicípio de Ribeirão Preto (SP). UNESP Rio Claro, 2004. Dissertação Mestrado - Programa de PósGraduação em Geografia - Área de Concentração em Organização do Espaço.

51. DIAS, G.F. INICIAÇÃO À TEMÁTICA AMBIENTAL ed. Gaia - São Paulo, 2002

52. Nações Unidas - Programa das Nações Unidas para o Desenvolvimento, Relatório do desenvolvimento humano 2007. ONU 2007. Disponível em: $<$ http://www.pnud.org.br/rdh/>. Acessado em: dezembro 2007.

53. GENOMA, Ricos tomam 6 vezes mais leite que pobres. Sitio de noticias, 2004. Disponível em:

<http://www.geomagna.com.br/canais/noticias/ler.php?id=12>, Acessado em: maio 2005

54. Carta Capital, Principais Conclusões do Pentágono, n. 280, março de 2004.

55. Nações Unidas - Intergovernmental Panel on Climate Change, Summary for Policymeakers, four Asessment Report, Work Group III, maio de 2007. Disponível em: <http://ipcc.bravehost.com/>. Acessado em: maio 2007.

56. NAÇÕES UNIDAS - Programa das Nações Unidas para o desenvolvimento, objetivos de desenvolvimento do milênio. Disponível em: <http://www.pnud.org.br/odm/index.php>. Acessado em: junho 2007.

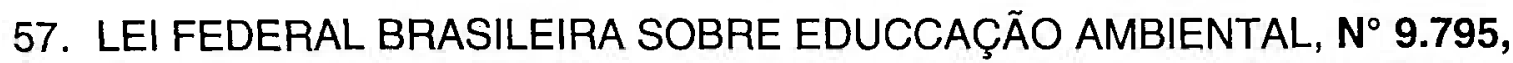
de 27 de abril de 1999. Disponivel em: <http://www.lei.adv.br/9795-99.htm>. Acessado em: outubro 2007.

58. IINSTITUTO IDEAL, "Educação ambiental é um desafio diário", afirma físico e parlamentar da Saxônia, 11 de agosto de 2007. Artigo sobre a palestra do parlamentar alemão Johannes Gerlach, realizada em Florianópolis, 11/08/2007. Disponivel em: $<$ http://www.institutoideal.org/index.php?sys=noticias\&\&id=117 $>$ Acessado em: setembro 2007. 
59. YAHOO NOTICIAS, Centro de vigilância climática global mais alto do mundo será no México. Sítio eletrônico de notícias, 24 de setembro de 2007. Disponivel em: $<$ http://br.noticias.yahoo.com/s/afp/070924/mundo/m xico meioambiente 2 >. Acessado em: outubro 2007.

60. THE GUARDIAM, Scientists offered cash to dispute climate study. Noticia de 2 de fevereiro de 2007. Disponível em:

$<$ http://www.guardian.co.uk/environment/2007/feb/02/frontpagenews.climatec hange>. Acessado em: março de 2007.

61. LINO, L. L.., CARRASCO, L.; COSTA, N.; PALACIOS, S. Máfia verde 2 ambientalismo. Novo colonialismo. Capax Dei Editora Ltda, Rio de Janeiro 2004.

62. MSIA - Movimento de Solidariedade Ibero-americana, A fraude do aquecimento global, MSIA 2007. Tradução Yára Mülle. Disponível no sítio eletrônico: <http://www.alerta.inf.br/index.php?news=722>. Acessado em: novembro 2006.

63. ASSOCIAÇÃO BRASILEIRA DO ALUMÍNIO, O alumínio: processos e produção - reciclagem, 2007, São Paulo. Disponível no sitio <http://www.abal.org.br/aluminio/processos reciclagem.asp >. Acessado em: novembro 2007.

64. ISO, 1997 Environmental Manegement - Life Cycle Assessment Principles and Frameworks International Standard ISO 14040.

65. GRACH, F. C.; Incorporação de resíduos de embalagens pós-consumo provenientes das agroindústrias na fabricação de bandejas de polpa moldada. USFC 2006 Dissertação de mestrado em Engenharia Química da Universidade Federal de Santa Catarina. SC 2006. Disponivel em <http://www2.enq.ufsc.br/teses/m165.pdf > Acessado em: outubro de 2007.

66. GONÇALVES, P.; Preciclel, Lixo Consulting, 2007. Disponivel em <www.lixo.com.br>. Acesso em: novembro 2007.

67. Naveiro, R. M., Pacheco, E. B. A. V., Medina H. de V.; O desenvolvimento de projeto de produto orientado para reciclagem. Trabalho apresentado no $5^{\circ}$ Congresso Brasileiro de Gestão de Desenvolvimento de Produto realizado entre 9 e 12 de Agosto de 2005, na PUC - Pontifícia Universidade Católica de Porto Alegre, RS, Brasil. Disponível em: <http://www.cetem.gov.br/publicacao/CTs/CT2006-005-00.pdf>. Acessado em; setembro 2007.

68. Revista Veja, ANBEV investe em reciclagem, n. 2031, 24 de outubro de 2007. Ed. Abril São Paulo. 
69. SOUZA, O. DE; VIEIRA V. Países e pessoas agem ...... mas alguns ainda duvidam. Ed. Abril Revista semanal Veja, ano 40, $n^{\circ} 42,24$ de outubro de 2007.

70. UNIVERSIDADE DE SÃO PAULO - SÃO CARLOS -CENTRO DE DIVULGAÇÃO DE CIENTÍFICA E CULTURAL; Célula de combustível. Disponivel em: < http://educar.sc.usp.br/quimapoio/cell.html>. Acesso em outubro 2007.

71. HARKER S.; O primeiro híbrido real. 2006. Disponivel em: $<$ http://www.earths-best-e-books.com/portuguese.php? u=/hybridcars/content/index.php>. Acessado em: junho 2006.

72. TOYOTA PORTUGAL; Manual do proprietário Prius, Lisboa, PORTUGAL. 2007. Disponivel em:

$<$ http://www.toyota.pt/brochures/brochures_models.aspx>. Acessado em: novembro de 2007.

73. TOYOTA PORTUGAL, Lista de preços de automóveis Toyota, 2007. Disponível em: <http://www.toyota.pt/cars/new cars/corolla/pricelist.aspx>. Acessado em 18 de novembro de 2007.

74. .DUNN, S.; Iceland sees the future - in hidrogen. Sitio Eletronico do GENI - Global Energy Institute, 26 , dezembro de 2000. Disponivel em: $<$ http://www.geni.org/globalenergy/library/technical-articles/generation/fuelcell/worldwatch-institute/iceland-sees-the-future-in-hydrogen/index.shtml>, acessado em: maio 2007.

75. BROWN, L.; Eco-economia. 2003EPI - Earth Policy Institute / UMAUniversidade Livre da Mata Atlântica. Disponível em: <www.uma.org.br>. Acessado em: junho 2005.

76. EMBAIXADA DA ALEMANHA. O setor de energia solar alemão espera crescer .Disponivel em:

<http://www.brasilia.diplo.de/Vertretung/brasilia/pt/aktuell/solar_energie.html caso da Alemanha solar>. Acessado em: outubro 2007.

77. SILVA, W. M.; O que é biodiesel. Sítio eletrônico do Polo Nacional de Biocombustíveis - ESALQ/USP. Disponível em:

$<$ http://www.polobio.esalq.usp.br/biocombustiveis.html?PHPSESSID $=52302 \mathrm{c}$ 5d7fccc516bc4752f2ac4873b3$>$. Acessado em: dezembro 2007.

78. CETESB, COMPANHIA DE TECNOLOGIA DE SANEAMENTO AMBIENTAL, A produção mais limpa $(p+l)$ no setor sucroalcooleiro. Câmara Ambiental do Setor Sucroalcooleiro GT de P+L: Mudanças Tecnológicas Procedimentos, CETESB. São Paulo, 2002. Disponivel em: $<$ http://www.cetesb.sp.gov.br/Tecnologia/camaras/texto ca/documentos/proc ao mais limpa sucroalcooleiro.pdf >. Acessado em: janeiro 2007. 
79. ALTAHYDE. J. A.; A crítica internacional aos biocombustiveis. Cenário Internacional. Disponivel em:

$<$ http://www.cenariointernacional.com.br/default3.asp?s=artigos2.asp\&id=48> Acessado em: novembro 2007.

80. PIACENTE E. A.; Agricultura para um desenvolvimento sustentável: cana-de-açúcar, Desenvolvimento Econômico e Meio Ambiente; Instituto de Economia UNICAMP, 2005.

81. GOLDEMBERG, J. Energia, meio ambiente \& desenvolvimento, São Paulo, SP - EDUSP, 1998.

82. REVISTA ENERGIA. Etanol vira plástico, Revista Energia Brasileira, 2007, n. 12, Araçatuba - SP.

83. PREFEITURA DE SÃO PAULO; Lei torna obrigatória a utilização de energia solar em novas edificações. Sítio eletrônico da Prefeitura Municipal de São Paulo, 05 de julho de 2007 Disponível no endereço eletrônico $<$ http://www.prefeitura.sp.gov.br/portal/a cidade/noticias/index.php?p=17192> . Acessado em outubro de 2007.

84. Imagem extraída do sitio eletrônico <http://amanatureza.com/projeto/wpcontent/uploads/2007/04/poluica02.jpg>. acessado em 03 de janeiro de 2008.

85. Sito de noticias Wordpress, Imagem extraída da Entrevista sobre a maratona na cidade de Beijim. Disponível em:

$<$ http://johnib.wordpress.com/category/beijing-games/>. Acessado em: novembro 2007.

86. SANTOS, R. R dos: Análise dos Vínculos entre os certificados Verdes e o Mecanismo de Desenvolvimento Limpo - A Perspectiva de Aplicação de Certificados Verdes no Brasil [Rio de Janeiro] 2005 XIII, 121p. 29,7cm (UFRJ/COPPE, M.Sc.,Planejamento Energético, 2005) Tese - Universidade Federal do Rio de Janeiro

87. Glasson, J.; Therivel, R.; Chadwick, A. Introduction to Environmental Impact Assessment. Principles and Procedures, Process, Pratice and Prospects. 2nd Edition. The Natural and Built Environment Series. T.J. International Ltd, Padstow, Inglaterra - 1999.

88. Therivel,R. et al. Strategic Environmental Assessment - Earthscan Publications Limited, Inglaterra - 1992.

89. ISO, 1997 Environmental Manegement - Life Cycle Assessment Principles and Frameworks International Standard ISO 14040.

90. Soderbaum, P. Economics and Ecological Sustainability. An actor-network approach to avaluation. Third International Workshop on Evaluation in Theory and Practice, Londres, - 1995. 
91. Turner,R.K. et al. Environmental Economics. An Elementary Introduction, Harvester Wheatsheaf, Hertfordshire, Inglaterra - 1994.

92. Schmit-Bleek,F. MIPbooks or The Fossilmakers - Factor $\mathbf{1 0}$ and More Wuppertal Institute for Climate, Environment and Energy, Alemanha - 1996.

93. WRI, World Resource Institute Resource Flows: The Basis of Industrial Economies World Resource Institute, EUA - 1997.

94. Ohta,T. Energy Technology - Sources, Systems and Frontier Conversion $1^{\text {st }}$ Ed. Pergamon , Inglaterra - 1995

95. SETAC-Europe Working Group on Conceptually Related Programmes - Life Cycle Assessment and Comceptually Related Programmes. Relatório do SETAC-Europa - 1997.

96. Odum, H; Emergy Accounting Environmental Engineering Sciences University of Florida, Gainesville, EUA - 2000. Disponivel em: $<$ http://www.fea.unicamp.br/docentes/ortega/htodum/emergyaccount.htm>. Acesso em Fevereiro/2005.

97. NOBEL FOUNDATION; Comitê da Fundação NOBEL, Que confere prêmios a quem contribuiu para o desenvolvimento da humanidade. Disponivel em: $<$ http://nobelprize.org/nobel_prizes/economics/laureates/1981/tobinautobio.html>. Acessado em: abril 2007.

98. TOBIN TAX INITIATIVE, Tobin taxes [...], how to tame hot money and fund urgent global priorities..., Center for Environmental Economic Development, Califórnia 2005, disponível em: $<$ http://ceedweb.org/iirp/factsheet.htm>. Acessado em: dezembro 2007.

99. EMBAIXADA FRANCESA; G8 sea island summit - press briefing given by $\mathrm{m}$. jacques chirac, president of the republic (excerpts), Sea Island 09.06.2004, Disponível em: < http://www.ambafrance-uk.org/G8-Sea-IslandSummit-Press.html>.Acessado em: maio 2005.

100.COELHO, M. C. C.; Restauração da mata ciliar pela viabilização de crédito de carbono: uma proposta sócio-ambiental para a comunidade de baixa renda. Dissertação de mestrado do Instituto de Pesquisas Energéticas e Nucleares da Universidade de São Paulo. São Paulo 2007.

101.REVISTA DA ASSOCIAÇÃO BRSILEIRA DE POLÍMEROS Disponível em: $<$ http://www.abam.com.br/revista/revista14/biopolimeros.php >. Acessado em> setembro 2007.

102.Schuwartz, B.; A tirania da escolha. Scientific Amercian - Brasil, ano 2, n. 24, maio de $2004-p, 62-67$. Ed. Ediouro 2004. 
103. New Economics Foundation; HAPPY PLANET INDEX 2007. Disponivel em $<$ http://www.happyplanetindex.org/download.htm>. Acessado em: dezembro 2007.

104.GRECO, A.: Entrevista com Aziz Ab'Saber - os meridianos da independência. Jornal da Ciência 20 de dezembro de 2004. Disponivel em: <http://www.jornaldaciencia.org.br/Detalhe.jsp?id=24184>. Acessado em: fevereiro 2006.

105. MATTAR, H. ; O consumo como ato de solidariedade. Folha de São Paulo, São Paulo, 03 de janeiro de 2003.

106. FOLHA DE SÃO PAULO, Noite_acentua inferno de Nova Orleans, notícia do dia 05 de setembro de 2005, sobre a devastação do furacão Katrina, disponivel no sitio $<$ http://www1.folha.uol.com.br/fsp/mundo/ft0509200501.htm>.Acessado em junho de 2007.

107. FOLHA ON LINE - Furacão chega à Louisiana com ventos de $233 \mathrm{~km} / \mathrm{h}$ 29/08/2005. Disponível no sitio $<$ http://www1.folha.uol.com.br/folha/mundo/ult94u87190.shtml >

108. IPCC - INTERGOVERNMENTAL PANEL ON CLIMATE CHANGE, Relatórios sobre mudanças climáticas. Disponivel em:

$<$ http://www.ipcc.ch/>. Acessado pela última vez em dezembro de 2007.

109. YAHOO NOTICIAS.; Mais de 1 bilhão de árvores foram plantadas em 2007. 28 de novembro de 2007. Disponível em: $<$ http://br.noticias.yahoo.com/s/afp/071128/saude/fran a ecologia clima $>$. Acessado em: novembro 2007. 